\title{
Waste Characterization for the F/H Affluent Treatment Facility in Support of Waste Certification (U)
}

by

D. F. Brown

Westinghouse Savannah River Company

Savannah River Site

Aiken, South Carolina 29808

DOE Contract No. DE-AC09-89SR18035

This paper was prepared in connection with work done under the above contract number with the U.S. Department of Energy. By acceptance of this paper, the publisher and/or recipient acknowledges the U.S. Government's right to retain a nonexclusive, royalty-free license in and to any copyright covering this paper, along with the right to reproduce and to authorize others to reproduce all or part of the copyrighted paper. 


\section{DISCLAIMER}

This report was prepared as an account of work sponsored by an agency of the United States Government. Neither the United States Government nor any agency thereof, nor any of their employees, makes any warranty, express or implied. or assumes any legal liability or responsibility for the accuracy, completeness, or usefulness of any information, apparatus, product, or process disclosed, or represents that its use would not infringe privately owned rights. Reference herein to any specific commercial product, process, or service by trade name, trademark, manufacturer, or otherwise does not necessarily constitute or imply its endorsement, recommendation, or favoring by the United States Government or any agency thereof. The views and opinions of authors expressed herein do not necessarily state or reflect those of the United States Government or any agency thereof.

This report has been reproduced directly from the best available copy.

Available to DOE and DOE contractors from the Office of Scientific and Technical Information. P. O. Box 62, Oak Ridge, TN 37831; prices available from (615) $576-8401$.

Available to the public from the National Technical Information Service, U. S. Department of Commerce, 5285 Port Royal Rd., Springfield, VA 22161 


\section{DISCLAIMER}

Portions of this document may be illegible in electronic image products. Images are produced from the best available original document. 
WESTINGHOUSE SAVANNAH RIVER COMPANY

HIGH LEVEL WASTE ENGINEERING

HIGH LEVEL WASTE ENGINEERING SUPPORT

WASTE CHARACTERIZATION FOR THE

F/H EFFLUENT TREATMENT FACILITY

IN SUPPORT OF WASTE CERTIFICATION (U)

by

D. F. Brown

ISSUED: October 17, 1994

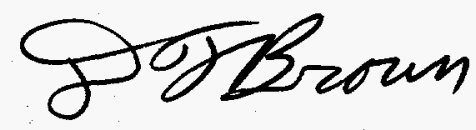

D. F. Brown, Author, HLWE

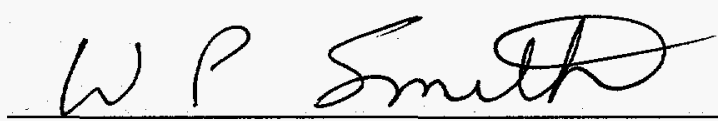

W. P. Smith, Technical Reviewer, HLWE ETF Cognizant Engineer

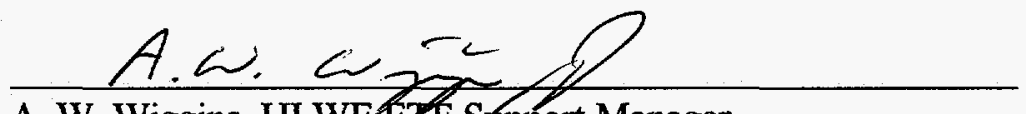

A. W. Wiggins, HLWE EPF Support Manager

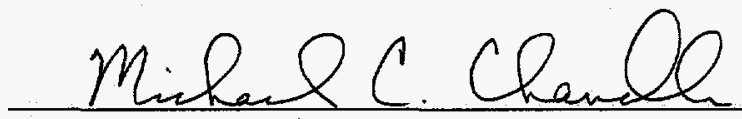

M. C. Chandler, HLWE Waste Characterization Manager

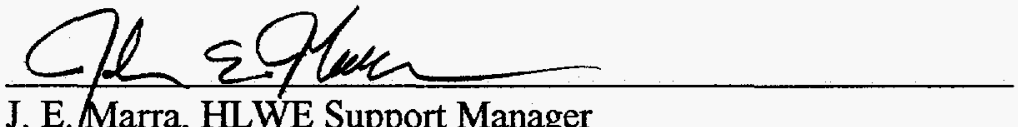

J. E.Marra, HLWE Support Manager

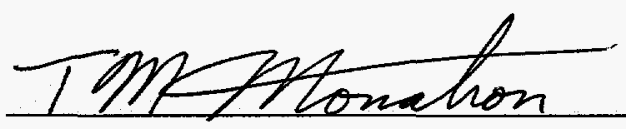

T. M. Monahon, HLWE Manager (Approved)
WSRC-TR-94-0427

REVISION: 1

KEYWORDS:

Waste Characterization

RETENTION:

Permanent

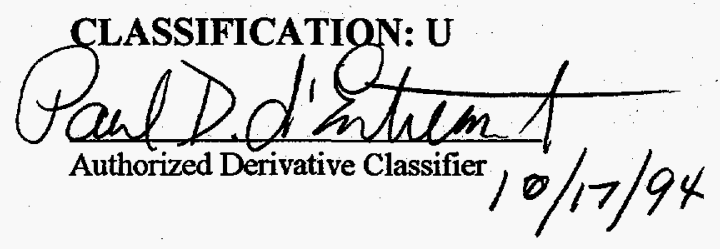

Date: $10 / 17 / 94$

Date: 101794

Date: $10 / 12 / 94$

Date: $10 / 17 / 94$

Date: $10 / 17 / 94$

Date: $10 / 17 / 94$ 
WSRC-TR-94-0427

Rev: $1(10 / 17 / 94)$

Page 2 of 48

\section{REVISION HISTORY:}

\begin{tabular}{|c|c|c|}
\hline Revision & Page & Change \\
\hline $0,9 / 7 / 94$ & --- & initial issue \\
\hline \multirow[t]{7}{*}{$\begin{array}{l}1, \\
10 / 17 / 94\end{array}$} & $\begin{array}{l}12-16 \\
\text { Table } 1 .\end{array}$ & $\begin{array}{l}\text { Enhanced ETF's activation \& fission product recipe to explicitly account for } \\
\text { radionuclides from Separations: } \\
\text { - Rev-0 used "soluble waste" (supernate). } \\
\text { - Rev-1 uses } 24 \% \text { of the "insoluble + soluble waste" (Separations overheads) plus } \\
76 \% \text { of the "soluble waste" (Tank Farm overheads). } \\
\text { - both recipes come from rev-0 of WSRC-TR-94-0292. }\end{array}$ \\
\hline & $\begin{array}{l}17-19, \\
\text { Table } 1, \\
\text { Table } 2 .\end{array}$ & $\begin{array}{l}\text { Enhanced ETF's actinide recipe by adding alternative recipes that could feed ETF: } \\
\text { - Rev-0 used only the Tank Farm supernate characterization. Also, U/Pu/Am/Np } \\
\text { were counted separately, not as a mixture in their actual proportions. This "double- } \\
\text { counting" (actually quadruple) was overly conservative. } \\
\text { - Rev-1 adds the potential U/Pu/Np/Am mixtures in the Separations process, and } \\
\text { develops the maximum composite (see the new Table-2). }\end{array}$ \\
\hline & $\begin{array}{l}\text { 12-19, } \\
\text { Table } 1 .\end{array}$ & $\begin{array}{l}\text { Revised the calculation methodology to scale directly from the HLW composition to } \\
\text { the ETF concentrate composition: } \\
\text { - Rev-0 took the tank farm characterization and mechanistically accounted for the } \\
\text { evaporator DF \& ETF volume reduction. This calculated a very conservative } \\
\text { volume of concentrate required to exceed each WAC. } \\
\text { - Rev-1 scales the combined HLW characterization's activation/fission products to } \\
\text { ETF's observed concentrate Cs-137; likewise the worst case actinide recipe is scaled } \\
\text { to ETF's observed gross-alpha. }\end{array}$ \\
\hline & 6. & $\begin{array}{l}\text { Enhanced discussion by quantifying ETF's historical contamination levels and } \\
\text { waste package dose rates (see new Figure-2) }\end{array}$ \\
\hline & 10. & $\begin{array}{l}\text { Elaborated on the "no-impact" that the "non-closure" in ETF's } \beta / \gamma \text { activity balance } \\
\text { has on the solid waste's characterization. }\end{array}$ \\
\hline & 12. & $\begin{array}{l}\text { Calculate the "other- } \beta / \gamma \text { " ( = "gross- }-\beta / \gamma " \text { " "Cs-137") instead of using the "gross- } \beta / \gamma \text { " } \\
\text { to bound the "other- } \beta / \gamma \text { " }\end{array}$ \\
\hline & 26. & Added paragraph on WAC criteria for fissiles, TRU, Class-C, and heat load. \\
\hline
\end{tabular}

Author's Credits: A previous series of reports ${ }^{2-7}$ characterizes the solid waste which is contaminated with HLW tank farm supernate. The tank farm evaporators process that supernate, producing the overheads which are ETF's primary source of wastewater influent. The evaporator overheads contain a trace amount of the supernate, so the ETF influent composition is basically a dilute version of the tank farm supernate. Parts of this report build upon and reference the supernate reports, and some of the text in this report is heavily paraphrased from the supernate reports. Preparation of this report has certainly benefited from utilizing previous reports written by M. C. Chandler ${ }^{2}$, P. D. d'Entremont ${ }^{2.7}$, C. E. Bess ${ }^{3}$, D. F. Brown ${ }^{4}$, J. S. Clemmons ${ }^{5}$, and G. K. Georgeton ${ }^{6}$. 
WSRC-TR-94-0427

Rev: 1 (10/17/94)

Page 3 of 48

INTRODUCTION \& SCOPE .............................................................................................................4

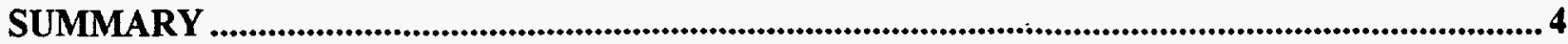

Radionuclides That Will Be Reported..................................................................................................5

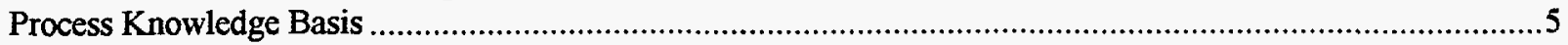

Smears \& Waste Package Exposure Rates ……………………………………………………………….....6

Future Characterization Enhancements ........................................................................................................

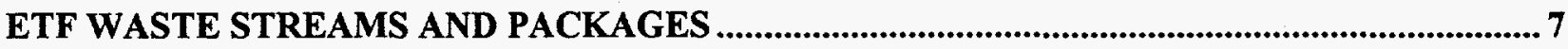

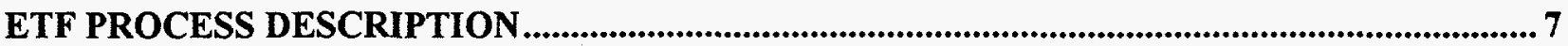

Process Sewer and Treatment Plant ............................................................................................................7

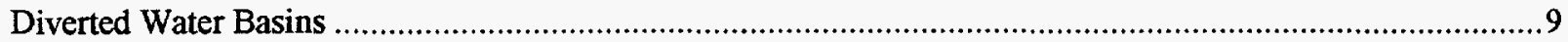

Sources of the Wastewater Treated at ETF ................................................................................................9

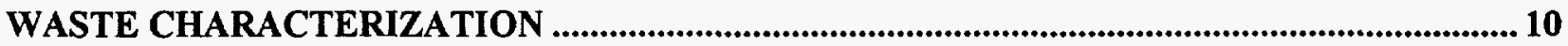

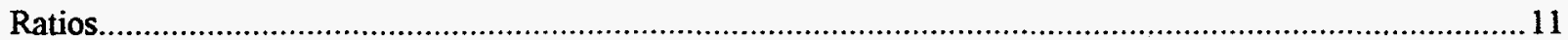

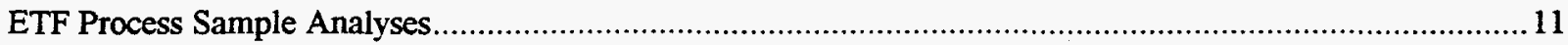

CHARACTERIZATION OF ETF's ROUTINE JOB WASTE -- "ETF-1(a)" …..........................11

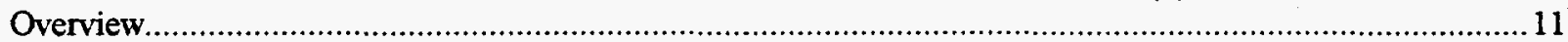

Using "Gross Alpha" to Bound "Other Alpha" .......................................................................................12

Using "Gross Beta/Gamma" to Bound "Other Beta/Gamma" .................................................................12

Scaling Other Radionuclides to Cs-137 and "Gross-Alpha"...................................................................12

Tritium and Other Activation Products...................................................................................................... 12

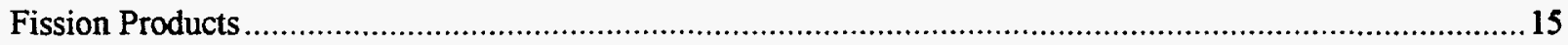

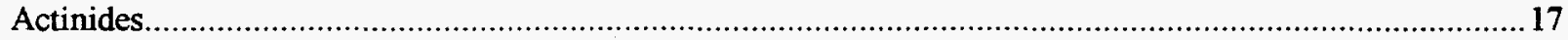

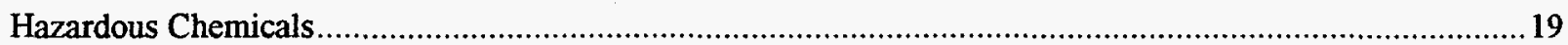

CHARACTERIZATION OF THE ADSORBENT WASTE STREAMS .......................................23

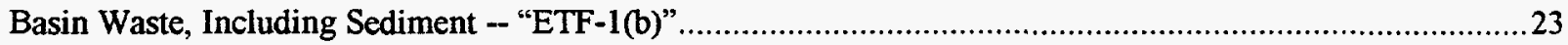

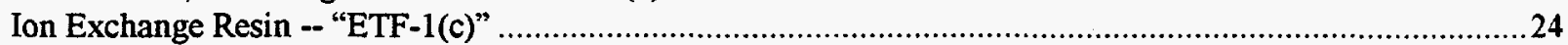

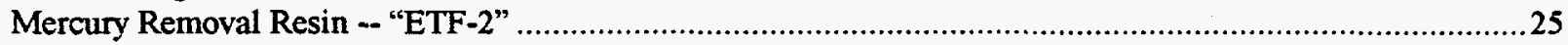

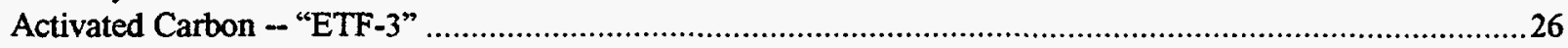

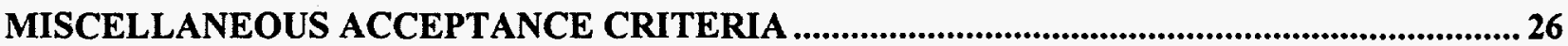

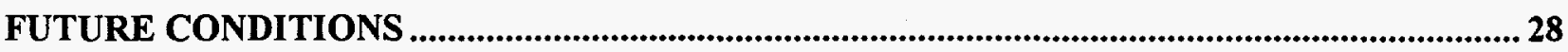

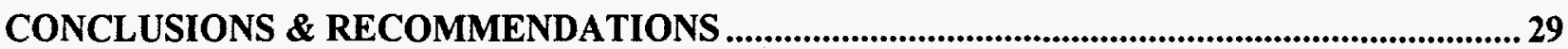

ATTACHMENTS:

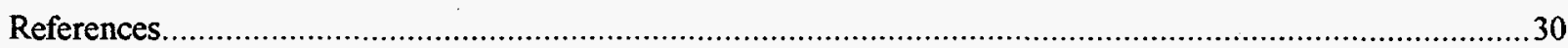

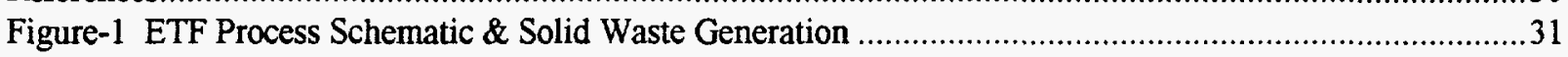

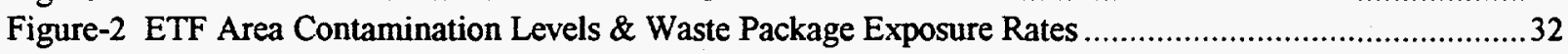

Table-1 PAC Volumes for ETF Job Waste......................................................................................... 33

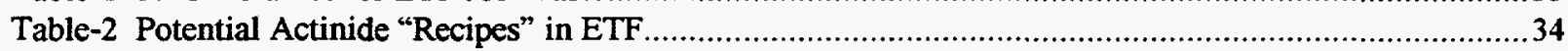

Table-3 Samples of ETF Adsorbent Wastes .............................................................................................35

Table-4 Detection Limits For ETF Adsorbent Waste Samples ...................................................................36

Chart-1 Origin of ETF Influent Activity ...................................................................................................3

Chart-2 Origin of ETF Influent Volume ..........................................................................................

Chart-3 Tank Farm Evaporators Decontaminate Supernate …………………………………………......39

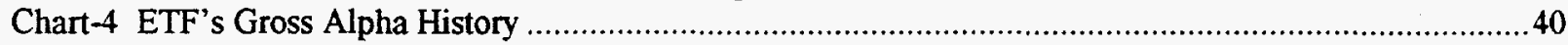

Chart-5 ETF's Gross Beta/Gamma History .....................................................................................41

Chart-6 ETF's Cesium-137 Fraction of Gross Beta/Gamma History ........................................................42

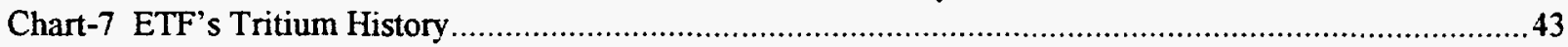

Chart-8 ETF's Co-60 History .......................................................................................................44

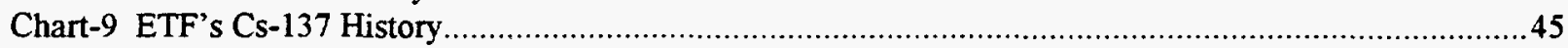

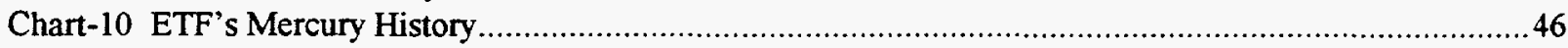

Chart-11 ETF's Chromium History .............................................................................................47

Chart-12 ETF's Arsenic, Barium, Cadmium, Lead, Selenium \& Silver History ..............................................48 
WSRC-TR-94-0427

Rev: $1(10 / 17 / 94)$

Page 4 of 48

\section{INTRODUCTION\&SCOPE}

The Waste Acceptance Criteria (WAC) procedures (e.g., sections 3.04 and 3.10 of the $1 \mathrm{~S}$ manual ') define the rules concerning packages of solid Low Level Waste (LLW) that are sent to the E-area vaults (EAV). The WACs tabulate the quantities of 22 radionuclides that require manifesting in waste packages destined for each type of vault. These quantities are called the Package Administrative Criteria (PAC). If a waste package exceeds the PAC for any radionuclide in a given vault, then specific permission is needed to send it to that vault. To avoid reporting insignificant quantities of the 22 listed radionuclides, the WAC defines the Minimum Reportable Quantity (MRQ) of each radionuclide as $1 / 1000^{\text {th }}$ of the PAC. If a waste package contains less than the MRQ of a particular radionuclide, then the package's manifest will list that radionuclide as zero. At least one radionuclide has to be reported, even if all are below the MRQ. The WAC requires that the waste not be "hazardous" as defined by SCDHEC/EPA regulations (e.g., RCRA), and also lists several miscellaneous physical/chemical requirements for the packages.

This report evaluates the solid wastes generated within the F/H Effluent Treatment Facility (ETF) for potential impacts on waste certification. This waste characterization report is part of ETF's overall Waste Certification Plan ${ }^{8}$. As shown in Figure 1 (page 31), the ETF boundary is defined as extending from the locations where the various generators release their wastewater (e.g., the tank farm evaporator overheads tanks), through the locations where the ETF waste concentrate and treated effluent streams are discharged (i.e., the riser on waste tank 50H, and the H-016 NPDES discharge weir at Upper Three Runs Creek). This scope includes the process sewers, lift stations, and treatment plant; as well as the storm water and cooling water basins and their NPDES outfalls and transfer route to the ETF process.

Wastewater treated at the ETF contains several of the WAC radionuclides and RCRA hazardous metals, so the solid waste produced by ETF will inevitably contain some amount of these species. The solid wastes are generated from operation, maintenance, and construction activities inside radiological areas. The solid wastes will be sent to the EAV, so their isotopic and hazardous characterization must be developed to demonstrate compliance with the WAC. This report develops the characterizations for ETF's various solid waste streams, so that appropriate controls can be implemented (as described in ETF's Waste Certification Plan ${ }^{8}$.

\section{SUMMARY}

The predominant waste stream generated at ETF is designated "ETF-1". Part of this stream consists of routine job wastes from the ETF lift stations and treatment plant ("ETF-1(a)") and is characterized by the process wastewater composition. The radionuclide characterization is based on process knowledge along with confirmatory sample data, and the hazardous chemical characterization is based on routine process sampling. Waste stream ETF-1 also encompasses the basin sediments, "ETF-1(b)", and an ion exchange resin, "ETF-1(c)". Since these could adsorb varying amounts of the radionuclides and chemicals, they are not represented by the wastewater composition. However, sample analysis of the ETF-l(b) and ETF-l(c) wastes show that they only contain Cs-137, so (when manifesting waste packages) they are grouped with the ETF-1(a) waste and are all called "ETF-1".

Note: The "(a)", "(b)", and "(c)" suffixes in the "ETF-1" waste stream designation are used only in this report, and only for clarity. For waste disposal purposes, these comprise one stream -which has a uniform composition/characterization.

ETF's two other solid waste streams (designated "ETF-2" and "ETF-3") can also adsorb varying amounts of the radionuclides and chemicals, so their characterizations are not represented by the wastewater composition. These solid wastes have also been characterized by analyzing waste samples.

Both the process knowledge and available sample data show that ETF solid wastes will meet the PAC, and that only a few species will exceed the MRQ. The composition of all ETF solid waste packages will be 
WSRC-TR-94-0427

Rev: $1(10 / 17 / 94)$

Page 5 of 48

appropriate for the Low Activity Waste Vaults (LAWV). However, based strictly on their physical size and weight, the ETF-3 spent activated carbon vessels may actually go to the Intermediate Level Vaults (ILV).

\section{Radionuclides That Will Be Reported}

Tritium and $\mathrm{Cs}-137$ are the predominant radionuclides in the wastewater treated through ETF. Most of the tritium ends up in the treated effluent and is discharged to a NPDES outfall. Compared to the LAWV's PAC for tritium ( $10 \mathrm{Ci})$, the tritium content of ETF wastewater is so low $(<0.0012 \mathrm{Ci} / \mathrm{gal})$ that tritium in the ETF-1 and ETF-2 packages will be manifested as zero. Only the activated carbon vessels are large enough to contain sufficient moisture to exceed the MRQ, therefore the ETF-3 manifests will include tritium.

The ETF treatment process concentrates most of the Cs-137 into a secondary liquid stream (called "ETF concentrate") that is eventually immobilized in Z-area Saltstone grout. The Cs-137 is in secular equilibrium with $\mathrm{Ba}-137^{\mathrm{m}}$ (a strong gamma emitter), and the Cs-137 inventories in ETF's solid waste packages will be determined from their external radiation exposure rates. Historically, the radiation surveys rarely detect anything above background, so most manifests will report the minimum detectable quantity of Cs-137. ETF's Waste Certification Plan ${ }^{8}$ and associated procedures contain additional information about determining the package's exposure rate and converting that exposure to its curie content.

To screen out insignificant radionuclides, an extreme case ETF-1 (a) waste package containing the contaminants from 100 gallons of ETF concentrate (equivalent to $\sim 8,000$ gallons of ETF influent) is compared to the LAWV PAC. This volume is sufficiently bounding that radionuclides meeting this screening criteria will be below MRQ in the actual average waste package. Table 1 (page 33) shows that this hypothetical ETF-1 (a) package would meet the LAWV PAC for all 22 radionuclides and the categories "other beta-gamma" and "other alpha", so they should all be manifested as zero. Since the WAC requires that at least one radionuclide be listed, the ETF-1 (a) package manifests will list Cs-137. This approach is similar to that used for waste tank supernate (as described in section D.2 "Methodology for Radionuclide Distribution Analysis" of reference 2).

Sample analyses of ETF-2 and ETF-3 wastes indicate that they also contain small amounts of Am-241.

In summary, the ETF waste manifests will list:

waste stream designation $\&$ contents

ETF-1

job waste from basins, lift stations and treatment plant; and HPK-25 resin

ETF-2 GT-73 mercury resin

ETF-3 activated carbon

\section{radionuclide}

Cs-137

Cs-137

Am-241

tritium

Cs-137

Am-241

\section{manifest value}

per dose to curie conversion

per dose-to-curie conversion, or resin sample $0.3 * \mathrm{Ci}_{\mathrm{C}-137}$

(vessel weight gain) * (recent process analysis) per dose-to-curie conversion, or carbon sample $1.5 * \mathrm{Ci}_{\mathrm{C}-137}$

\section{Process Knowledge Basis}

The radionuclide characterization of waste stream ETF-1(a) is based largely on process knowledge of the ETF wastewater composition, which combines information from various sources. Knowledge of the processes by which the wastewater was generated (primarily the HLW tank farm evaporators and the Separations evaporators) is combined with process sample data for several radionuclides. This 
WSRC-TR-94-0427

Rev: $1(10 / 17 / 94)$

Page 6 of 48

combination yields an estimate of the amounts of other radionuclides in the ETF wastewater. Estimating the quantities of radionuclides that could accumulate in a waste package assumes that the proportions of radionuclides in the package are the same as in the ETF process wastewater. This is consistent with the mechanisms for contamination of low-level solid waste, i.e., direct contact of the solid waste with ETF process wastewater, and entrapment of liquid aerosols. Volatilization is not a credible mechanism for contaminating the solid waste because (with two exceptions) the radionuclides of concern are non-volatile under ETF conditions. While tritium oxide is volatile, it will not be concentrated by volatilization because it evaporates at approximately the same rate as "normal" water (i.e., protium and deuterium oxides). The moderately acidic ETF process solutions ( $\mathrm{pH}$ from 1.5 to 5) may volatilize some I-129 (i.e., as $\mathrm{HI}$ or $\mathrm{I}_{2}$ ), but there is no known mechanism for the volatile form to be deposited. Since any resultant atmospheric emission of I-129 only reduces the amount available to contaminate the solid waste, assuming no I-129 "losses" results in a slightly conservative characterization of the solid waste.

\section{Smears \& Waste Package Exposure Rates}

Minimizing the amount of contamination is a high priority at ETF, and this naturally results in solid waste that is minimally contaminated. Although the process tanks and treatment building have forced ventilation through HEPA filters, a large portion of the ETF is outdoors (e.g., the basins, and most of the process tanks and pumps). Thus, any contamination released may cause environmental contamination. The lack of environmental contamination is confirmed through the Radiological Control Operations (RCO) smear program, along with other programs such as personnel bioassays, exposure monitoring (TLD), whole body counts, and portal monitors.

Contamination of job waste can occur when smearable contamination is present. In many instances, job waste is generated in Radiologically Controlled Areas (RCAs) or Radiological Buffer Areas (RBAs), yet no significant quantity of smearable contamination is present. Whether actual contamination is present or not, any waste generated is still considered to be low level radioactive waste. Job waste can also be contaminated with "fixed" contamination. Fixed contamination has the same composition of radionuclides as smearable contamination (in the same contamination area) and both are characterized by dose-to-curie determination.

At ETF, the radiological areas (i.e., RBAs and CAs) are monitored for transferable contamination by RCO personnel in accordance with Survey Procedure 133 (Manual 5Q1.2). As shown in Figure 2 (page 32), the $\sim 186,000 \mathrm{ft}^{2}$ radiological buffer area (RBA) meets the established "clean area" limits. Of the $\sim 25,000 \mathrm{ft}^{2}$ contamination area (CA), over $99 \%$ normally meets the "clean area" limits. Of the $\sim 211,000 \mathrm{ft}^{2}$ total, only $\sim 50 \mathrm{ft}^{2}$ normally shows transferable contamination, and even that is at relatively low levels. As shown in Figure 2, a waste package would have to contain over 418,000 meter $^{2}$ of surface area contaminated at $40,000 \mathrm{dpm}_{\beta \gamma} / 100 \mathrm{~cm}^{2}$ in order to reach the LAWV's $0.76 \mathrm{Ci}$ PAC for Cs-137. For comparison, this is $>100$ acres, or $>21 x$ the surface area of ETF's entire RBA/CA.

The external exposure rates of ETF's waste packages have been surveyed, and Figure 2 (page 32) shows the 1994 results (thru September). All (18) B-25 boxes showed no increase above background, so they (typically) contained $<0.04 \mathrm{Ci}_{\mathrm{Cs}-137}$ (for a $\leq 2000 \mathrm{lb}$ net weight, measuring $\leq 1 \mathrm{mR} / \mathrm{hr}$ at $5 \mathrm{ft}$ ). In the future, packages with such low rates will be measured at $5 \mathrm{~cm}$, so (in this example) the reported inventory would be $<0.005 \mathrm{Ci}_{\mathrm{Cs}-137}$. Of the (172) cardboard boxes shown in Figure 2, the (2) boxes which read $2 \mathrm{mR} / \mathrm{hr}$ would be manifested as containing $0.007 \mathrm{Ci}_{\mathrm{Cs}-137}$. Of the (121) cardboard boxes where a "micro- $\mathrm{R}$ " meter was used, $100 \%$ would have been manifested as $<0.001 \mathrm{Ci}_{\mathrm{Cs} .137}$. These dose-to-curie determinations are not sensitive enough to show that the packages are $<M R Q$ for the LAWV and $253-\mathrm{H}\left(0.00076 \mathrm{Ci} \mathrm{css}_{-137}\right.$ and $0.000063 \mathrm{Ci}_{\mathrm{Cs}-137}$ respectively), so Cs-137 will be listed in the manifests (besides, they must list at least one radionuclide) 
WSRC-TR-94-0427

Rev: $1(10 / 17 / 94)$

Page 7 of 48

\section{Future Characterization Enhancements}

The development of an enhanced sampling program for all of HLW is under consideration ${ }^{12}$. This program may involve analyzing wastewater and solid waste for more of the WAC radionuclides, and it may involve smearing solid waste samples. This would add confidence in the existing characterization information and supplement the data available for making process knowledge determinations. The smear's detection limits would probably not be able to quantify the low level of radionuclides actually present, but they could provide assurance that ETF's solid waste packages do not exceed the PAC.

\section{ETF WASTE STRFAMSAND PACKAGES}

The solid waste generated at ETF is split into three "streams" and subsequent sections of this report discuss the characterization/composition of each stream:

- ETF-l consists of:

- routine job waste from the lift stations and treatment plant -- ETF-l(a),

- routine job waste from the basins, including basin sediment -- ETF-1(b),

- an ion exchange resin used to remove traces of Cs-137 -- ETF-1(c),

- ETF-2 is another ion exchange resin used to remove mercury,

- ETF-3 is activated carbon, used to remove organics ("packaged" in the $10^{\prime} \times 20^{\prime}$ process vessel),

Waste can be divided into three categories: 1) compactable (e.g., rubber gloves, cloth, swipes, plastic bags); 2) non-compactable (e.g., resins, filter cartridges, scrap metal); and 3) suspect soil/rubble (e.g., basin sediment, asphalt, gravel, crusher run, sandy clay). Most waste is packaged into cardboard boxes, or B-12 and B-25 boxes. These solid wastes are correctly segregated, packaged, handled and transported, as described in ETF's Waste Certification Plan ${ }^{8}$.

ETF gerferates approximately $2200 \mathrm{ft}^{3}$ of compactable waste each year. Before being compacted at the 253-H compactor facility, this volume is equivalent to 400 cardboard boxes (each $21 " \times 21 " \times 21 "=5.36 \mathrm{ft}^{3}$ ). Part of this volume is actually packaged in cardboard boxes, and part is placed directly in magenta B-25 boxes. The 253-H compactor crushes the contents of the B-25 boxes, then additional cardboard boxes are added and crushed until the B-25 is full. Each cardboard box has to weigh less than 50 pounds, have an external exposure rate less than $50 \mathrm{mrem} / \mathrm{hr}$ Beta Gamma at $5 \mathrm{~cm}$, and originate in an area posted as $<20$ $\mathrm{dpm} / 100 \mathrm{~cm}^{2}$ smearable alpha contamination. The ETF waste characterization developed in this report applies equally to the 253-H Compactor and the LAWV. The compactor PAC values (i.e., WAC 3.04) are $1 / 12^{\text {th }}$ of the LAWV PAC values (i.e., WAC 3.10), but this reduction does not affect the ETF characterization.

ETF generates approximately (75) B-12 boxes and (30) B-25 boxes each year. These boxes are made from 12 and 14 gauge steel (respectively); have an approximate capacity of 5,000 lbs; and volumes of 45 and 90 $\mathrm{ft}^{3}$. These yellow boxes are used for non-compactable waste, such as cartridge filter elements, resin, soil and rubble, wood, pipes, equipment, etc. Additionally, some $(\leq 5) 55$-gallon drums of spent resin and $(\leq 2)$ activated carbon vessels $\left(-10^{\prime}\right.$ dia $\times 20^{\prime}$ tall, weighing $\left.-66,000 \mathrm{lb}\right)$ will be generated each year.

Historically, $100 \%$ of the compactable waste packages and $99 \%$ of the non-compactable packages have had no detectable gamma on the field radiological survey instrumentation. The waste packages are surveyed to determine the external exposure reading, and their $\mathrm{Cs}-137$ curie content is estimated by assuming that the exposure readings are due to the $0.662 \mathrm{MeV}$ gamma of $\mathrm{Ba}-137^{\mathrm{m}}$ (which is in secular equilibrium with Cs-137). ETF's Waste Certification $\operatorname{Plan}^{8}$ and associated procedures contain details about determining external exposure rates and $\mathrm{Cs}-137$ contents. 
WSRC-TR-94-0427

Rev: $1(10 / 17 / 94)$

Page 8 of 48

\section{ETE PROCESS DESCRIPTION}

The ETF collects, treats, and discharges the radioactively contaminated wastewater (primarily evaporator overheads) from the High Level Waste Division (i.e., the tank farms) and also from the Separations Division. The ETF treatment process splits the "influent wastewater" stream into two streams: the high volume "treated effluent", and the low volume "waste concentrate".

Note: In this document, the terms "wastewater", "influent" and "concentrate" refer to ETF's liquid process streams; while "waste" refers to the solid LLW destined for the EAV (which contains contaminants from the liquid streams).

\section{Process Sewer and Treatment Plant}

Various wastewater generators discharge dilute liquids (primarily evaporator overheads from the tank farm and Separations facilities) into the process sewers. The sewers drain by gravity to ETF's F\&H area lift stations, where the wastewater is pumped to the ETF Treatment Plant. As shown in Figure 1 (page 31), the ETF treatment process decontaminates the influent wastewater through a series of steps. After the treatment steps remove specific species, the treated effluent is analyzed and discharged to the environment through a NPDES permitted outfall.

Solid wastes are generated by several of the ETF treatment steps:

- To maximize solids removal and reduce fouling in the filter system, the wastewater influent is $\mathrm{pH}$ adjusted and treated with filter aids (aluminum nitrate and/or ferric nitrate).

- Ceramic sub-micron filters produce a small volume liquid side-stream of concentrated suspended solids that have been removed from the wastewater. The filters are chemically cleaned, and are replaced when the cleaning is unsuccessful -- contributing to waste stream ETF-1(a).

- Ion exchange resin (Rohm \& Haas "Duolite GT-73") is used to remove heavy metals, primarily mercury. Bacteria accumulations are removed by cleaning the resin in caustic, and the resin is replaced when it is fully loaded with $\mathrm{Hg}$ - this is waste stream ETF-2.

- Activated carbon removes organics, primarily the solvent used by Separations, i.e., tributyl phosphate (TBP) and n-paraffin hydrocarbon (NPH). When the carbon is "loaded", the process vessel that contains the carbon is replaced, i.e., the process vessel is also the disposal container - this is waste stream ETF-3.

- Cartridge filters remove carbon fines and bacteria from the organic removal effluent. The filter elements are chemically cleaned, and are replaced regularly - contributing to stream ETF-1(a).

- Reverse osmosis (RO) produces a small volume liquid side-stream of concentrated dissolved salts that have been removed from the wastewater. The RO membranes are chemically cleaned, and are replaced when the cleaning is unsuccessful -- contributing to waste stream ETF-1(a).

- Ion exchange resin (Mitsubishi "Diaion HPK-25") removes remaining traces of Cs-137. The resin is regenerated as needed and is replaced when the regeneration is ineffective -- waste ETF-l(c).

- The filter and RO side-streams, cleaning solutions, and regenerants (described in the preceding steps) are then sent to the ETF evaporator for further concentration. The evaporator overheads are routed back to the ETF process. Most of the contaminants end up (even more concentrated) in the evaporator bottoms concentrate stream, which is then neutralized with excess caustic and sent to tank $50 \mathrm{H}$ (and eventually is immobilized in Z-area Saltstone grout).

As shown in Chart 2 (page 38), since the ETF startup in 11/88, a total influent volume of 94.53 million gallons has resulted in a total concentrate volume of 1.175 million gallons. This is a 80:1 volume reduction between the wastewater influent and the evaporator concentrate (i.e., -1 gallon of concentrate is produced for each 80 gallons of influent). Aside from tritium and mercury, essentially all of the influent contaminants end up in the evaporator concentrate. The $\sim 80: 1$ volume reduction is reflected in the process 
WSRC-TR-94-0427

Rev: $1(10 / 17 / 94)$

Page 9 of 48

sample analyses, which show "concentrate" concentrations that are $\sim 80 \mathrm{x}$ higher than "influent" concentrations (except for tritium and mercury). The tritium content of all the ETF process streams is uniform, so most of the tritium goes to the treated effluent. While part of the influent mercury is removed (by adsorption on the GT-73 resin), the remainder ends up in the concentrate stream, which has a higher $\mathrm{Hg}$ concentration than the ETF influent (just not the full $\sim 80 \mathrm{x}$ higher).

Since the concentrate's concentrations are higher than the influent's, they are used to characterize the ETF-1(a) solid waste stream.

\section{Diverted Water Basins}

The Separations Department normally discharges their non-contact cooling water directly to the environment, after monitoring to ensure that it is not radioactively contaminated. Likewise, the HLW tank farms (including ITP/ESP) monitor and discharge their uncontaminated storm water. If the water is contaminated, the generators divert it to the ETF basins. Based on the source and degree of contamination, ETF segregates the diverted water among four large lined basins - a "cooling water basin" and a "retention basin (which receives storm water and any excess cooling water) in each of $\mathrm{F}$-area and $\mathrm{H}$-area. The generators also have several administrative or precautionary reasons for diverting the cooling water or storm water to the ETF basins. For example: storm zones are diverted when the tank farm is conducting a (liquid) waste transfer, or when a zone's water monitor is out of service (or initiates a false alarm). When the water collected in ETF's basins is sampled, it normally meets the clean discharge limits, so it is then discharged to various NPDES outfalls.

Over an extended period, the basins accumulate mud and sand that is periodically removed. For clarity in this report, the sediment will be called ETF-1(b). It will be sent to the EAV with the same waste characterization as all of waste stream ETF-1.

Although it is a rare event, the basin water samples can show that the water is actually contaminated. This has only occurred once in ETF's 5.5 year operating history, although ETF's original design basis anticipated a frequency of about once per year. Regardless of the frequency, when the water is contaminated, it can be sent to the ETF treatment plant, and (once HDB-8 becomes operational) the water could be sent to the tank farms, or alternative treatment could be provided (e.g., Chem-Nuclear treated the $8 / 89$ diversion). When the diverted water is not suitable for direct discharge, a "real" diversion is considered to have occurred, and the basin sediment will have to be re- characterized. In this case, the particular radionuclide distribution and amounts adsorbed in the sediment may be based either on the characterization of the source of the contamination, or on sample analyses. This requirement needs to be identified in ETF's operating procedures.

\section{Sources of the Wastewater Treated at ETF}

Solid waste generated by ETF will be contaminated with the wastewater that is treated through ETF. That wastewater originates predominantly as overheads from evaporators operated by the Separations Division and the High Level Waste Division (i.e., the tank farms).

The large majority of ETF's influent activity results from evaporating supernate in the tank farm evaporators. As shown in Chart 1 (page 37), since startup in late 1988 over $76.6 \%$ ETF's total influent beta/gamma activity came from the tank farm evaporators (i.e., $8.29 \mathrm{Ci}_{\mathrm{Cs}-137}$ measured in the overhead tank release samples, compared to $10.81 \mathrm{Ci}_{\beta / \gamma}$ measured in the daily Lift Station samples). Thus only $23.4 \%$ of ETF's influent activity originates in the Separations Department evaporators, and even that fraction results from processing the high level wastes that eventually go to the tank farm. Compared to the first six years of ETF operation, the future SRS mission involves even less operations in Separations, and more in HLW, so the fraction of ETF's influent activity originating in the tank farms will only increase. 
Incidentally, Chart 1 (page 37 ) implies that only $44.7 \%$ of ETF's influent activity $\left(10.81 \mathrm{Ci}_{\beta \gamma}\right)$ has "left" in ETF's concentrate stream (i.e., $\left.4.83 \mathrm{Ci}_{\beta / \gamma}\right)$-- the remaining $\sim 55 \%\left(5.98 \mathrm{Ci}_{\beta / \gamma}\right)$ is unaccounted for. This disparity has not been reconciled, and may be due to sampling or analytical difficulties related to the suspended solids in the concentrate stream. Other factors in the ETF "activity balance" do not "close" the balance (e.g., the treated effluent, the "in-process inventory", solid wastes, etc), these only account for $<1$ $\mathrm{Ci}$ of the "missing" activity. For example, Chart 1 also shows the cumulative beta/gamma content of ETF's treated effluent stream (as shown in Chart 5, page 41, these are almost always below the ETF Lab's minimum reporting value). The original minimum value $(5 \mathrm{~d} / \mathrm{m} / \mathrm{ml})$ was changed to $1 \mathrm{~d} / \mathrm{m} / \mathrm{ml}$ in $11 / 90$, corresponding to the slope change in the cumulative total. The lack of "closure" has no impact on the characterization of ETF's solid waste streams, since essentially all of ETF's beta/gamma is Cs-137 (see Chart 6, on page 42 ). If the "missing" activity (mostly Cs-137) were present in a solid waste package, it would be appropriately quantified (per the exposure rate and dose-to-curie conversion) and would be manifested properly.

The activity level of the tank farm evaporator's overhead stream is drastically lower than that of the evaporator's supernate feed, but the overheads do contain slight amounts of entrained supernate. Chart 3 (page 39) shows that the evaporator overheads always contain $<1 / 200,000^{\text {th }}$ as much $\mathrm{Cs}-137$ as the supernate feed, and that the typical reduction is more often $1 / 500,000$ to $1 / 2,000,000$. The overheads are typically $3 \cdot 10^{-7}$ to $4 * 10^{-6} \mathrm{Ci} / \mathrm{gal}(=200-2500 \mathrm{~d} / \mathrm{m} / \mathrm{ml})$, compared to typical supernate feed at $1-20 \mathrm{Ci} / \mathrm{gal}$. Except for tritium and mercury (which are volatile), this reduction factor applies to all contaminants present in the waste tank supernate. In Separations, High Level Waste Management, and ETF, the tritium is present as an oxide (i.e., HTO), whose physical and chemical "behavior" (e.g., evaporation) is the same as ordinary water (i.e., $\mathrm{H}_{2} \mathrm{O}, \mathrm{HHO}$ ). Thus the tritium content of tank farm evaporator overheads is the same as the supernate feed, and this uniformity of composition continues throughout the ETF process. Aside from dilution with fresh water, all ETF liquid streams have the same tritium content. Likewise, part of the mercury in the supernate volatilizes into the evaporator overheads, as metallic $\mathrm{Hg}$. At ETF, extensive process sample analyses for both tritium and mercury demonstrate compliance with the PAC (as discussed later in this report).

As shown in Chart 2 (page 38), the tank farm evaporator overheads comprises a relatively small fraction of ETF's influent volume (i.e., 11.46 million gallons, of the 94.53 million gallon total). Since tank farm overheads are only $12.1 \%$ of ETF's influent volume yet are $76.6 \%$ of ETF's influent activity, it is evident that the wastewater coming from Separations is very dilute. Separation's evaporator overheads results from processing the high level wastes that eventually go to the tank farm, so the tank farm supernate characterization will be used to approximate the relatively minor contribution from Separations. Chart 2 also shows that ETF has released a total of 125.9 million gallons to the NPDES outfall, reflecting the $\sim 30.2$ million gallons of water that ETF has added into the treatment process (cleaning solutions, rain water, etc).

Several other sources contribute minor volumes of wastewater and amounts of radioactivity/chemical contamination (e.g., the ETF Lab, several sinks and floor drains in the Tritium facilities, the 772-F lab evaporators, 100-area trailers brought to Separation's General Purpose evaporators). In this report, the individual compositions of these sources are accounted for in the ETF process liquid samples that are discussed in the following sections. The RCRA regulations on "listed" waste provide several exemptions (e.g., use of certain reagents in a Lab), and the site Labs are sensitive to proper disposal of un-used reagents. As will be discussed in a subsequent section, the ETF cannot receive any RCRA "listed" waste. 


\section{WASTE CHARACTERIZATION}

\section{$\underline{\text { Ratios }}$}

One useful way to compare the waste's composition to the PAC involves the radionuclide ratios, i.e., Ci of a given radionuclide per $\mathrm{Ci}$ of $\mathrm{Cs}-137$. This " $\mathrm{Ci} / \mathrm{Ci}$ ratio" is calculated by dividing the two radionuclide concentrations or amounts -- i.e., $\mathrm{Ci}_{\text {radionuclide }}$ gallon / $\mathrm{Ci}_{\mathrm{Cs}-137} / \mathrm{gallon}$, or $\mathrm{Ci}_{\text {radionuclide }} /$ package / $\mathrm{Ci}$ Cs-137/package. If the waste stream ratios for all radionuclides are less than the PAC ratios, then Cs-137 is the limiting radionuclide. Otherwise the package's allowable Cs-137 content can be reduced such that the package's content of each radionuclide remains within the PAC values. If a package exceeds the LAWV PAC, then it may be sent to a "higher level" vault (e.g., the ILV instead of the LAWV), or it may be accepted for the LAWV with additional permission and special handling.

The $\mathrm{Ci} / \mathrm{Ci}$ ratio relates directly to the waste certification program's methodology, where the waste package's external radiation exposure rate is measured, the Cs-137 content is determined (via the "dose-to-curie" conversion factors), and then the other isotope contents are calculated by their "scaling factors" (i.e., these $\mathrm{Ci} / \mathrm{Ci}$ ratios).

Note: In this document, the term "Ci/Ci ratio" refers to the ratio of a particular radionuclide to Cs-137.

\section{ETF Process Sample Analyses}

The ETF wastewater samples (including influent, treated effluent, and waste concentrate) are analyzed in the ETF Analytical Laboratory, following the ETF Lab Procedures Manual L3.2. The "gross alpha" and "gross beta/gamma" analyses are counted (using scalers) by the ETF RCO lab. The "gamma PHA" analyses for Co-60 and Cs-137 are performed by the 772-F Central Lab, and prior to 10/93 the tritium analyses were done by the SRTC Environmental Transport Section and the 232-H Tritium Facility Lab.

The results are reported to the ETF Operations group, and (for much of the ETF operating history) they have been tabulated by HLWE personnel (currently M.D.D.Goodman). The values and charts discussed in this section come from the HLWE tabulation. While there are some gaps visible in the charts, the large number of analyses extending over the majority of ETF's history (since its 11/88 startup), provides confidence that the values used in this report are representative of ETF operation.

\section{CHARACTERIZATION OF ETF's_ROUTINE.JOB WASTE - "ETF-1G"}

\section{Overview}

This section characterizes the solid waste stream ETF-1(a) that is "contact contaminated" with the wastewater that is treated at ETF. "Contact contaminated" describes the situation where the proportions of radionuclides and chemicals in the solid waste are the same as their proportions in the process liquid (e.g., such as results from cleaning up a spill). In this situation, the amount of contamination is variable, but the type is not. In contrast, the other ETF wastes (i.e., ETF-1(b), -1 (c), -2 , and -3) can adsorb particular radionuclides or chemicals, so their characterizations may not be represented by the wastewater's composition. These latter streams are addressed in subsequent sections of this report.

In this report, the volume of ETF concentrate required to exceed various PAC values is discussed. Of course, the waste package does not have to actually contain the liquid concentrate, but merely the contamination from that volume of concentrate. For example, over an extended period a process leak could have dripped many gallons which have since evaporated, leaving only a "small" residue. In the case of ETF's concentrate, $\sim 20 \%$ of the original volume would remain as saltcake (the concentrate is a $\sim 25 \mathrm{wt} \%$ solution of $\mathrm{NaOH} / \mathrm{NaNO}_{3} /$ etc). Thus, when this report calculates a 100 gallon volume of concentrate, 
remember that even if that volume dried up, it would still leave a 20 gallon pile of salt. Alternatively, since the concentrate is $\sim 80 \mathrm{x}$ more concentrated that the ETF influent, $\sim 8,000$ gallons of influent would be required to contaminate the waste package (and after evaporation the same -20 gallon pile of salt cake would remain).

\section{Using "Gross Alpha" to Bound "Other Alpha"}

The WAC provides PAC values for several specific radionuclides that emit alpha ( $\alpha$ ) radiation, and also for the general category of "other- $\alpha$ ". Much of the "gross- $\alpha$ " in ETF wastewater consists of specific radionuclides that are discussed in the "actinide" section of this report, but it is certainly conservative to show that "gross- $\alpha$ " analyses meet the PAC for "other- $\alpha$ ".

At ETF, "gross- $a$ " has been monitored regularly in the influent and concentrate, and Chart 4 (page 40) shows the $>1760$ and $>125$ analyses (respectively). As expected from the treatment process $\sim 80: 1$ volume reduction, the concentrate values are $\sim 80 \mathrm{x}$ higher than the influent values (values reported as " $<\mathrm{X}$ " are charted and averaged as "X"). At the average "gross- $\alpha$ " analysis $(0.00000016 \mathrm{Ci} /$ gal $)$, a waste package would have to contain the activity from $>22,500$ gallons of concentrate in order to exceed the LAWV's "other- $\alpha$ " PAC (0.0037 Ci). Thus the "other- $\alpha$ " in ETF-1(a) packages will be manifested as zero.

\section{Using "Gross Beta/Gamma" to Bound "Other Beta/Gamma"}

The WAC provides PAC values for several specific radionuclides that emit beta ( $\beta$ ) and gamma $(\gamma)$ radiation, and also for the general category of "other- $\beta / \gamma$ ". As shown on Chart 6 (page 42 ), essentially all of ETF's "gross- $\beta / \gamma$ " consists of $\mathrm{Cs}-137$, so the $\mathrm{Ci}_{\text {other }-\beta / \gamma}$ may be bounded by subtracting the $\mathrm{Ci}_{\mathrm{Cs}-137}$ from

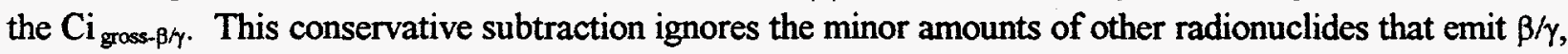
e.g., Sr-90.

At ETF, "gross- $\beta / \gamma$ " has been monitored regularly in the influent and concentrate, and Chart 5 (page 41) shows the $>1755$ and $>435$ analyses (respectively). Likewise, Cs-137 has been monitored regularly in ETF's influent and waste, and Chart 9 (page 45) shows the $>335$ and $>195$ analyses (respectively). As expected, the concentrate values are $\sim 80 \mathrm{x}$ higher than the influent values, reflecting the treatment process $\sim 80: 1$ volume reduction (values reported as " $<X$ " are charted and averaged as " $X "$ ). Chart 6 (page 42) shows that Cs-137 essentially accounts for all of the "gross- $\beta / \gamma$ " (if all the $\beta / \gamma$ were Cs-137 and all analyses were "perfect", then all the results would be on the $\mathrm{Y}=\mathrm{X}$ line). Results "above" the line must indicate sampling or analytical scatter (since Cs-137 can't exceed $\beta / \gamma$ ), and results "below" the line could also indicate the presence of $\beta / \gamma$-emitting radionuclides other than $\mathrm{Cs}-137$. Subtracting the Cs-137 average $(0.0000083 \mathrm{Ci} / \mathrm{gal})$ from the "gross- $\beta / \gamma$ " average $(0.000011 \mathrm{Ci} / \mathrm{gal})$ yields the "other- $\beta / \gamma$ " $(0.00000267$ $\mathrm{Ci} / \mathrm{gal})$. At the concentration, a waste package would have to contain the activity from $>859,800$ gallons of concentrate in order to exceed the LAWV's "other $-\beta / \gamma$ " PAC $(2.3 \mathrm{Ci})$. Thus the "other- $\beta / \gamma$ " in ETF-1(a) packages will be manifested as zero.

\section{Scaling Other Radionuclides to Cs-137 and "Gross-Alpha"}

Of the 22 radionuclides listed in the WAC, ETF has an extensive process sample analysis history for tritium, Co-60, and Cs-137. The concentrations of the remaining activation and fission products can be estimated by scaling them according to the measured Cs-137, and the actinide concentrations can be estimated by apportioning ETF's measured gross alpha. These methodologies are discussed in the subsequent sub-sections. 


\section{Tritium and Other Activation Products}

Note: A large portion of this sub-section has been paraphrased from previous reports ${ }^{2,3}$. In the following discussion of activation product sources and tank farm supernate inventories, see reference 3 for details.

Activation products are radionuclides produced in the reactor as a result of neutron bombardment of materials in the fuel and target assemblies. Four of the 22 radionuclides of concern for LLW Certification are activation products: tritium (H-3), carbon-14, nickel-59, and cobalt-60.

\section{Tritium, H-3}

Tritium originates as a fission product and as a result of neutron capture by heavy water moderator.

In HLW supernate, the amount of tritium received is a function of the 100-area reactor's irradiation and process schedules, and of the fraction removed by canyon evaporators before the solutions reach the waste tanks. The tritium generated in reactor fuel and targets (as a result of fission) has a minor impact on HLW. Based on a fission yield analysis for a 5 year decay, the amount of tritium is only $2.85 \mathrm{Ci}$ per assembly compared to $2920 \mathrm{Ci}$ of Cs-137 per assembly, so tritium starts at a concentration $\sim 1 / 1000^{\text {th }}$ of Cs-137. The LAWV PAC for tritium $(10 \mathrm{Ci})$ is $\sim 13 \mathrm{x}$ higher than the $\mathrm{Cs}-137 \mathrm{PAC}(0.76 \mathrm{Ci})$, so there is $\mathrm{a} \sim 13,000 \mathrm{x}$ difference between cesium and tritium relative to the PAC. The concentration of fission product tritium is low relative to its PAC, and since tritium cannot be concentrated in $\mathrm{HLW}$, there is no potential for fission yield tritium to impact LLW.

The other source of tritium is neutron activation of deuterium (heavy water) in the reactor moderator. Tank 17F received a large volume of tritiated water directly from $\mathrm{K}$-reactor, and it is the exception that bounds the tank farm supernate's tritium concentration. Tank 17F contains 6000 curies in 274,000 gallons (including the 112,000 gallons received from K-Reactor). Even at this concentration ( $0.022 \mathrm{Ci} / \mathrm{gal})$, a supernate contaminated waste package would have to contain over 450 gallons of liquid from tank $17 \mathrm{~F}$ to exceed the tritium PAC.

At ETF, tritium has been monitored regularly in the influent and in the treated effluent, and Chart 7 (page 43) shows those $>305$ and $>945$ analyses (respectively). The 100-areas send low level tritiated wastewater to Separation's General Purpose Evaporator (GPE), and the GPE overheads go to the ETF, resulting in the high spikes in ETF's wastewater tritium concentrations. As expected from the physical behavior of the tritium "water", the ETF influent and effluent analyses do not reflect any change through the ETF process (i.e., either concentration or removal). At ETF's average concentration $(0.0000629 \mathrm{Ci} / \mathrm{gal})$, a waste package would have to contain the tritium from $>158,800$ gallons of effluent in order to exceed the LAWV PAC (10. Ci). Thus the tritium in ETF-1(a) packages will be manifested as zero.

\section{Carbon, C-14}

Carbon-14 can be produced by three reactions: ${ }^{14} \mathrm{~N}(\mathrm{n}, \mathrm{p}){ }^{14} \mathrm{C} ;{ }^{17} \mathrm{O}(\mathrm{n}, \alpha){ }^{14} \mathrm{C}$; and ${ }^{13} \mathrm{C}(\mathrm{n}, \gamma){ }^{14} \mathrm{C}$. At SRS, almost all of the $\mathrm{C}-14$ is produced from the ${ }^{17} \mathrm{O}(\mathrm{n}, \alpha){ }^{14} \mathrm{C}$ reaction in reactor moderator. Oxygen-17 is a constituent of the moderator, comprising $0.038 \%$ of the total oxygen. Carbon- 14 is also produced by the other two reactions, but their contributions to SRS production of C-14 are negligible because nitrogen and carbon are available in reactor processes only as trace impurities. The most useful way to specify the C-14 production rate is as "Ci/KMWD" (curies per thousand megawatt days). This is a charge dependent quantity, with high production rates at higher thermal neutron fluxes. It ranges from 0.064 Ci/KMWD (for Mark 16-31 operation) to $1.11 \mathrm{Ci} / \mathrm{KMWD}$ (for the high flux charges operated in the mid 60 's).

Fuel and targets entering Separations are dissolved under either caustic or acidic conditions. In a nitric acid dissolution the $\mathrm{C}-14$ would have been liberated to the atmosphere as $\mathrm{CO}_{2}$, and in a caustic dissolution 
WSRC-TR-94-0427

Rev: $1(10 / 17 / 94)$

Page 14 of 48

it would form various carbonates. Analysis done during the DWPF flowsheet development ${ }^{3 a}$ determined that fresh waste (before separating into sludge and supernate phases) contains $1.8 \cdot 10^{-7} \mathrm{Ci}_{\mathrm{C}-14} / \mathrm{gal}$ and 2.8 $\mathrm{Ci}_{\mathrm{Cs}-137} /$ gal (i.e., a ratio of $6.4 * 10^{-8} \mathrm{Ci} / \mathrm{Ci}$ ). That analysis also determined that $75 \%$ of the $\mathrm{C}-14$ is insoluble, so the tank farm evaporator feed has a ratio of $1.6 * 10^{-8} \mathrm{Ci} / \mathrm{Ci}$. Activity entrained into the evaporator overheads would have the same ratios, and (as discussed previously) $76.6 \%$ of the activity entering ETF comes from the tank farm evaporators. Thus the "weighted" ratio estimated for ETF is 2.7 * $10^{-8} \mathrm{Ci} / \mathrm{Ci}(=0.234 * 6.4 \mathrm{E}-8+0.766 * 1.6 \mathrm{E}-8)$. ETF's average concentrate composition is $8.3 \cdot 10^{-6} \mathrm{Ci}_{\mathrm{cs}-137} / \mathrm{gal}$ (as will be discussed below), so the estimated $\mathrm{C}-14$ concentration is $2.19 * 10^{-13} \mathrm{Ci} /$ gal. At this concentration, an ETF-1(a) waste package would have to contain the C-14 from 15,070,000,000 gallons of ETF concentrate in order to exceed the LAWV PAC $(0.0033 \mathrm{Ci})$. Thus the C-14 in ETF-1(a) packages will be manifested as zero.

Note that naturally occurring C-14 present in all organic materials (e.g., rubber gloves, plastics, etc) is not reported on the waste manifests ${ }^{1}$.

\section{Nickel, Ni-59}

Nickel-59 is produced by the neutron activation reaction $-{ }^{58} \mathrm{Ni}(\mathrm{n}, \gamma){ }^{59} \mathrm{Ni}-$ during irradiation of reactor assemblies. The natural abundance of ${ }^{58} \mathrm{Ni}$ is $68.3 \%$, and nickel is present in SRS assemblies as an impurity in aluminum cladding and as a coating on uranium slugs. Nickel is also present in non-SRS reactor fuels (RBOF fuels) as a component of stainless steel cladding.

In $\mathrm{HLW}$, a history of $\mathrm{Ni}(\mathrm{OH})_{2}$ stored in waste tanks showed that the $\mathrm{Ni}-59$ abundance in 15-year aged waste was $0.239 \%$. Production equations were used to calculate the ratio of ${ }^{58} \mathrm{Ni} /{ }^{59} \mathrm{Ni}$ for the various fuel and target assemblies which were irradiated in SRS reactors (e.g., Mark-16B, -22, -31A, -31B, and -53A). The ratios were weighted by the assembly's resultant waste proportions to determine the HLW average ratio, and $\mathrm{Ni}(\mathrm{OH})_{2}$ inventory data was used to determine the amount of $\mathrm{Ni}(63.32 \%)$. The $\mathrm{Ni}-59$ content was calculated by multiplying the mass of $\mathrm{Ni}$ by the percent abundance in 15 -year waste, and the specific activity of $\mathrm{Ni}-59(0.0808 \mathrm{Ci} / \mathrm{g})$ was used to convert the amount of $\mathrm{Ni}-59$ to curies. The concentration of $\mathrm{Ni}-59$ per waste tank was then computed by dividing the number of curies of $\mathrm{Ni}-59$ by the total volume (gallons) of waste received into that tank. For the purposes of this calculation, the nickel was conservatively assumed to be completely soluble.

Analysis done during the DWPF flowsheet development ${ }^{3 \mathrm{a}}$ determined that fresh waste (before separating into sludge and supernate phases) contains $5.1 * 10^{-6} \mathrm{Ci}_{\mathrm{Ni}-5 \%} / \mathrm{gal}$ and $2.8 \mathrm{Ci}_{\mathrm{Cs}-137} / \mathrm{gal}$ (i.e., a ratio of $1.8 * 10^{-6}$ $\mathrm{Ci} / \mathrm{Ci}$ ). That analysis also determined that only $0.019 \%$ of the Ni-59 is soluble, so the tank farm evaporator feed has a ratio of $3.4 * 10^{-10} \mathrm{Ci} / \mathrm{Ci}$. Activity entrained into the evaporator overheads would have the same ratios, and (as discussed previously) $76.6 \%$ of the activity entering ETF comes from the tank farm evaporators. Thus the "weighted" ratio estimated for ETF is $4.3 \cdot 10^{-7} \mathrm{Ci} / \mathrm{Ci}(=0.234 \cdot 1.8 \mathrm{E}-6+$ $0.766 \cdot 3.4 \mathrm{E}-10$ ). ETF's average concentrate composition is $8.3 \cdot 10^{-6} \mathrm{Ci}_{\mathrm{cs}-137} / \mathrm{gal}$ (as will be discussed below), so ETF's estimated Ni-59 concentration is $3.48 * 10^{-12} \mathrm{Ci} / \mathrm{gal}$. At this concentration, an ETF-1 (a) waste package would have to contain the $\mathrm{Ni}-59$ from 18,100,000,000 gallons of ETF concentrate in order to exceed the LAWV PAC ( $0.063 \mathrm{Ci})$. Thus the Ni-59 in ETF-1(a) packages will be manifested as zero.

\section{Cobalt, Co-60}

Cobalt is a minor constituent in structural materials (e.g., stainless steel), and cobalt-60 is produced by neutron activation of ${ }^{59} \mathrm{Co}$ and ${ }^{60} \mathrm{Ni}$. There is no credible mechanism to produce significant quantities of $\mathrm{Co}-60$ in canyon feed. Neutron activation of natural ${ }^{60} \mathrm{Ni}$ in the target's nickel cladding $-{ }^{60} \mathrm{Ni}(\mathrm{n}, \mathrm{p})^{60} \mathrm{Co}-$ is assumed to be the major source of $\mathrm{Co}-60$ in the waste.

In HLW supernate, the best available data is actual analyses of Co-60 in waste tank supernate (ref: "Radionuclide Sample Analysis of Waste Tanks 1-51", J.A.Pike, HLW-HLE-94-0328, 01/24/94). The 
average concentration of $\mathrm{Co}-60$ from available tank samples is $0.0249 \mathrm{Ci} / \mathrm{gal}$, and the maximum concentration measured is $0.17 \mathrm{Ci} /$ gal. Unlike the other activation products, the concentration of $\mathrm{Co}-60$ can be measured in HLW because Co-60 emits a strong gamma $(\gamma)$ that is readily detected, whereas other WAC radionuclides are beta $(\beta)$ emitters.

At ETF, Co- 60 has been monitored regularly in the influent and concentrate, and Chart 8 (page 44) shows the $>360$ and $>195$ analyses (respectively). Most values were actually reported as " $<X$ " but are charted and averaged as "X", so compared to the "influent" data, the "concentrate" analyses does not appear to reflect the $-80: 1$ volume reduction. At ETF's average concentrate concentration $(0.000 .000081 \mathrm{Ci} / \mathrm{gal})$, a waste package would have to contain the Co-60 from $>282,000,000$ gal of concentrate to exceed the LAWV PAC (23. Ci). Thus the Co-60 in ETF-1(a) packages will be manifested as zero.

\section{Fission Products}

Note: A large portion of this sub-section has been paraphrased from previous reports ${ }^{2,4}$. In the following discussion of fission product sources and tank farm supernate inventories, see reference 4 for details.

In the 100-area reactors, a wide distribution of "fission products" (FP) results from splitting the uranium and plutonium atoms. Each FP atom is a fragment of the original U/Pu atom, and is either a non-radioactive "stable" radionuclide, or else it is the radioactive "parent" of a "daughter" atom. The daughter atom can either be stable, or it can be the parent of yet another generation of daughter. For each FP radionuclide, its atoms can be present from both mechanisms -- some of its atoms may have been formed directly, and while others may be the decay daughters which originated as some other FP radionuclide.

Six fission products are listed in the WAC:

- selenium, Se-79, which decays to bromine:

As-79 (half life of 9 minutes) $\rightarrow$ Se-79 $(65,000$ years) $\rightarrow$ Br-79

- strontium, $\mathrm{Sr}-90$, which decays to niobium:

$\mathrm{Kr}-90$ (half life of 32.3 seconds) $\rightarrow->\mathrm{Rb}-90^{\mathrm{m}}$ ( 258 seconds) \& Rb-90 (157 seconds) -->> Sr-90 (28.6 years) $\rightarrow$ Y-90 (64.1 hours) $\rightarrow$ Zr-90 (14.6 hours) $\rightarrow$ Nb-90

- technetium, Tc-99, which decays to ruthenium:

Mo-99 (half life of 66.0 hours) $\rightarrow$ Tc-99m (6.0 hours) \& Tc-99 (213,000 years) $\rightarrow$ Ru-99

- tin, Sn-126, which decays to tellurium:

Sn-126 (half life of 100,000 years) $\rightarrow$ Sb-126m (19 minutes) \& Sb-126 (12.4 days) $\rightarrow$ Te-126

- iodine, I-129, which decays to xenon:

Sb-129 (half life of 4.4 hours) ---> Te-129m (33.6 days) \& Te-129 (69.6 minutes) ---> I-129 $(15,700,000$ years $) \rightarrow$ Xe-129

- cesium, Cs-137, which decays to barium:

Xe-137 (half life of 3.8 minutes) $\rightarrow$ Cs-137 (30.17 years) $\rightarrow->$ Ba-137m $(2.52 \mathrm{~min}) \rightarrow$ Ba-137

The amount of each FP radionuclide produced in the 100-area nuclear reactors depends primarily on two factors. First is the fissionable atom isotope distribution (e.g., the \% of U-233, -235, -238; Np-237; Pu-238, -239, etc), which is largely determined by the particular type of fuel/target assembly (e.g., Mark-16, -22, -31A, -31B, -53A, offsite fuel). These assemblies contain either enriched U-235 (the reactor's fuel, in the Mark-16's and a part of the Mark-22 assembly), or depleted U-238 (producing Pu-239 in Mark-31A and -31B), or Np-237 (producing Pu-238 in Mark-53A). The second factor determining the FP production is the reactor operating conditions (e.g., flux rate, megawatt-days, etc). However, regardless of the different assemblies and their operating conditions, the relative amounts of each of the six FPs produced is reasonably consistent, i.e., they all have similar $\mathrm{Ci} / \mathrm{Ci}$ ratios. This means that the exact origin of the ETF influent wastewater is not significant. That is, overheads from a tank farm 
WSRC-TR-94-0427

Rev: $1(10 / 17 / 94)$

Page 16 of 48

evaporator being fed HM supernate (from Mark-16, -22 , and -53A processed in $\mathrm{H}$-area) will be similar to overheads containing some entrained PUREX supernate (from Mark-31A and -31B processed in F-area).

If all the FP atoms in the fuel/target assemblies went to the waste tanks and stayed in the supernate, then the reactor production $\mathrm{Ci} / \mathrm{Ci}$ radionuclide ratios would also apply to the evaporator overheads, and thus would also apply to the ETF influent. In reality however, there are two "partition factors" which impact the overheads $\mathrm{Ci} / \mathrm{Ci}$ ratios. When Separations dissolves the assemblies in nitric acid, part of the iodine is volatilized into the dissolver off-gas system. Part of that volatile I-129 is collected as silver iodide (on silver coated Berl saddles). Originally, the silver iodide coating was dissolved and flushed to the waste tanks; later the coated rings either went to Solid Waste or remain in Separations. These "losses" reduce the I-129/Cs-137 ratio for ETF wastewater to $40 \%$ of the reactor production $\mathrm{Ci} / \mathrm{Ci}$ ratio value. In the waste tank's caustic environment, the I-129 will be present as non-volatile soluble salts (i.e., sodium iodide and sodium iodate). Aside from iodine, essentially $100 \%$ of the other FP radionuclides produced in the reactors go to the waste tanks. The second "partition factor" that impacts the composition of the evaporator overheads is the solubility of various radionuclides in the waste tank's highly caustic environment. Many of the radionuclides are only slightly soluble at high $\mathrm{pH}$, so most of those curies end up in the waste tank sludge layer, i.e., the supernate only contains a fraction of the original activity. The supernate fractions range from essentially $100 \%$ (e.g., I-129, Cs-137), to a moderate amount (e.g., Tc-99 $=57 \%$, Se-79 $=$ $10 \%, \mathrm{Sn}-126=4 \%$ ), to a very small fraction (e.g., $\mathrm{Sr}-90=0.025 \%$ ). The supernate fractions were determined empirically during development of the DWPF process, from analyses of supernate samples. Thus the supernate fraction includes both the true chemical solubility and other "physical" effects such as suspended colloidal particulates.

As discussed previously, $76.6 \%$ of ETF influent beta/gamma has come from the tank farm evaporators, and $23.4 \%$ has come from Separations. Thus ETF's process composition is a weighted average of the Separations composition ("before" applying the partition factors), and the tank farm supernate composition (after applying the factors). The weighted mixture can then be scaled to the ETF's observed Cs-137 concentration:

\begin{tabular}{|c|c|c|c|c|c|}
\hline & $\begin{array}{l}\text { waste fed to } \\
\text { Separations } \\
\text { evaporators } \\
\text { Ci/gal } \\
\end{array}$ & $\begin{array}{c}\text { partition } \\
\text { fractions to } \\
\text { waste \& } \\
\text { supernate } \\
\end{array}$ & $\begin{array}{l}\text { waste fed to } \\
\text { Tank Farm } \\
\text { evaporators } \\
\text { Ci/gal } \\
\end{array}$ & $\begin{array}{c}76 \% / 24 \% \\
\text { weighted } \\
\text { waste } \\
\text { Cigal } \\
\end{array}$ & $\begin{array}{l}\text { scaled to Cs-137 } \\
\text { observed in ETF's } \\
\text { concentrate } \\
\text { Ci/gal }\end{array}$ \\
\hline Se-79 & $1.61 \mathrm{E}-05$ & 1. \& 0.1 & $1.61 E-06$ & $5.00 \mathrm{E}-06$ & $1.46 \mathrm{E}-11$ \\
\hline Sr-90 & 2.88 & 1. \& 0.00025 & $6.70 \mathrm{E}-04$ & $6.28 \mathrm{E}-01$ & $1.83 \mathrm{E}-06$ \\
\hline Tc-99 & $5.53 \mathrm{E}-04$ & 1. \& 0.57 & $3.15 E-04$ & $3.71 \mathrm{E}-04$ & $1.08 \mathrm{E}-09$ \\
\hline $\mathrm{Sn}-126$ & $1.71 \mathrm{E}-06$ & 1. \& 0.04 & $6.84 \mathrm{E}-08$ & $4.53 \mathrm{E}-07$ & $1.32 \mathrm{E}-12$ \\
\hline I-129 & $9.42 \mathrm{E}-07$ & $0.4 \& 1$ & $3.77 \mathrm{E}-07$ & $5.09 \mathrm{E}-07$ & $1.48 \mathrm{E}-12$ \\
\hline Cs-137 & 2.85 & 1. \& 1 . & 2.85 & 2.85 & $8.30 \mathrm{E}-06$ \\
\hline
\end{tabular}

Note that there is no "partition factor" for the evaporators, since all FP radionuclides will be equally entrained into the overheads stream (i.e., all radionuclide $\mathrm{Ci} / \mathrm{gal}$ concentrations decrease equally). Mechanistically, the factor of $343,000 \mathrm{x}$ between the $2.85 \mathrm{Ci} / \mathrm{gal}$ waste composition and ETF's $8.3 \cdot 10^{-6}$ $\mathrm{Ci} / \mathrm{gal}$ is a result of the evaporator's "decontamination factor $(-2,000,000 \mathrm{x}$, as shown in Chart 3 , page 39$)$, and ETF's volume reduction factor $(-80 x$, as shown in Chart 2 , page 38$)$.

As shown in Table 1 (page 33), the activity from extremely large volumes of ETF concentrate would be required to exceed the LAWV PAC for Se-79, Sr-90, Tc-99, Sn-126, and I-129. Thus these radionuclides in ETF-1 (a) packages will be manifested as zero.

At ETF, Cs-137 has been monitored regularly in the influent and waste, and Chart 9 (page 45) shows the $>335$ and $>195$ analyses (respectively). As expected, the concentrate values are $\sim 80 \mathrm{x}$ higher than the influent values, reflecting the treatment process $\sim 80: 1$ volume reduction (values reported as " $<\mathrm{X}$ " are charted and averaged as "X"). To equal the LAWV PAC for Cs-137 (0.76 Ci), a waste package would 
WSRC-TR-94-0427

Rev: $1(10 / 17 / 94)$

Page 17 of 48

have to contain $>91,500$ gallons of average concentrate $(0.0000083 \mathrm{Ci} / g a l)$. ETF's waste packages cannot even hold such a large volume, but the ETF-1(a) manifests will list Cs-137 since the WAC requires that at least one radionuclide be listed.

Aside from Cs-137, none of the other FP radionuclides will be listed in ETF's solid waste package manifests since they will all be $<\mathrm{MRQ}$. If any of the other FP radionuclides were to be manifested, their scaling factors would be the "evaporator overheads $\mathrm{Ci} / \mathrm{Ci}$ " values shown above. Even though I-129 is slightly more limiting than $\mathrm{Cs}-137$, it will also be $<\mathrm{MRQ}$. For example, a waste package contaminated with $1 / 2$ gallon of ETF concentrate would contain $4.15 * 10^{-6} \mathrm{Ci}_{\mathrm{Cs}-137}$ and $7.4 * 10^{-13} \mathrm{Ci}_{\mathrm{I}-129}$. In this example package, Cs- 137 would be $1 / 183,100^{\text {th }}$ of its PAC $(0.76 \mathrm{Ci})$; and $\mathrm{I}-129$ would be $1 / 112,000^{\text {th }}$ of its PAC $\left(8.3 * 10^{-8} \mathrm{Ci}\right)$. While $\mathrm{I}-129$ is a larger fraction of its PAC than $\mathrm{Cs}-137$ is of its PAC, the I-129 would not be reported since it is $<1 / 1000^{\text {th }}$ of its PAC. There is no reason to select I-129 as "the" radionuclide to manifest, since Cs-137 would still be determined first (from the dose-to-curie conversion). Depending on the detection capabilities of the instrument used to determine the package's exposure rate, the minimum detectable Cs-137 content will be artificially elevated. In that situation it is deemed preferable to report "artificial Cs-137" rather than "artificial I-129".

\section{Actinides}

Note: A large portion of this sub-section is paraphrased from previous reports ${ }^{2,5}$. In the following discussion of actinide sources and tank farm supernate, see reference 5 for details.

The HLW supernate inventory of uranium (U), plutonium (Pu), neptunium (Np), and americium (Am) has been characterized based on the chemical, isotopic and radiological properties of these elements. The actinide inventories in HLW waste tanks are a direct reflection of the nuclear material processing that occurred in F- and H-Canyons. For example, when highly enriched uranium is processed in the canyon, then uranium losses to waste will be highly enriched. Essentially all actinides present in HLW resulted from material sent to waste from $\mathrm{F}$ - and $\mathrm{H}$ - Canyons. Acidic canyon wastes are neutralized to one molar excess $\mathrm{NaOH}$ prior to transfer to $\mathrm{HLW}$, and the actinides are only slightly soluble in alkaline solutions. When the canyon waste streams are neutralized, the bulk of these elements co-precipitate with other waste diluents such as iron, manganese, aluminum and numerous others. Co-precipitation with other waste diluents generally precludes the actinides from reaching their solubility concentrations. The precipitated elements settle in the sludge layer at the bottom of the tank, and the small fraction of actinides that remains soluble will eventually pass through an evaporator system.

Uranium, U-233, U-234, U-235, U-236, U-238

Uranium exists naturally, but in most SRS applications the uranium isotopic distribution was quite different from that found in nature. Uranium has sixteen isotopes, all of which are radioactive. Naturally occurring uranium has only three isotopes (U-238, U-235, and U-234). The wt\% of naturally occurring isotopes was manipulated to suit the application need. For example, a high content of U-238 is desired when producing $\mathrm{Pu}-239$, thus uranium depleted in $\mathrm{U}-235$ was used as the target material (this is typical of waste from PUREX reprocessing). For the reactor fuel, a higher than natural content of U-235 is desired, thus uranium enriched in U-235 was used (this is typical of HM reprocessing). Recovery and reuse of enriched uranium fuel and special production campaigns produced the isotopes U-236 and U-233.

SRTC solubility studies of uranium in alkaline solutions (i.e., supernate) demonstrate that:

- U solubility is very low (1-20 mg/), regardless of hydroxide concentrations (0.1-17 molar).

- Concentrations of $\mathrm{U}$ in HLW supernate samples are low, and are consistent with the solubility data. 
WSRC-TR-94-0427

Rev: $1(10 / 17 / 94)$

Page 18 of 48

- $\mathrm{U}$ is not a significant contributor to the HLW supernate alpha activity.

In HLW, uranium is a minor constituent of the activity (curies). The total HLW uranium activity is only 196 curies, compared to the plutonium activity which is estimated to be over 3.5 million curies. Of the 196 uranium curies, U-233 and U-234 account for almost $70 \%$. On a mass basis, these isotopes are only present in trace quantities and are limited to $\mathrm{H}$-area waste tanks.

Plutonium, Pu-238, Pu-239, Pu-240, Pu-241, Pu-242

Plutonium is formed by irradiation of uranium with neutrons, and trace quantities exist in naturally occurring uranium ores. There are fifteen known isotopes of plutonium (all of which are radioactive). At SRS, plutonium was produced in large quantities for use as a heat source ( $\mathrm{Pu}-238)$ and for fuel or nuclear weapons material (Pu-239). A few special production campaigns used plutonium as a target material to produce higher isotopes, but these campaigns were limited in their number and the total mass of material. The target material, irradiation process and separation were manipulated to produce plutonium concentrated in the desired isotope.

SRTC solubility studies have consistently demonstrated that the solubility of plutonium is lower than that of uranium. In actual waste tank supernate, the plutonium concentration is normally less than $0.5 \mathrm{mg} /$, and all sample analyses have been less than the reported solubility value of $1.68 \mathrm{mg} /$ (the accuracy of these samples cannot be confirmed, and sample data is not available for all waste tanks). After neutralization, the bulk of the plutonium coprecipitates with other waste components such as iron and manganese, thus keeping the plutonium from reaching its saturation concentration.

The HLW waste tank total plutonium inventory is estimated at $3.5 \cdot 10^{6} \mathrm{Ci}$, of which Pu-238 and Pu-241 are the dominant nuclides. One third of the entire HLW plutonium activity is located in tank $39 \mathrm{H}$, and over $75 \%$ of the plutonium is contained in tanks $32 \mathrm{H}, 35 \mathrm{H}$ and $39 \mathrm{H}$. These tanks received fresh waste from H-Canyon when Low Assay Plutonium was sent to waste.

Neptunium, Np-237

Neptunium is formed by irradiating uranium with neutrons, and it exists in trace quantities in naturally occurring uranium ores. The solubility of $\mathrm{Np}$ in alkaline waste has not been extensively studied, and there is also a lack of supernate sample data. Undocumented studies on $\mathrm{Np}$ during simulated waste evaporation showed that $\mathrm{Np}$ is more soluble than U, Pu or Am. SRTC precipitation experiments showed that 70-99\% of the Np sent to waste adsorbed onto sludge particles during the precipitation process, which is consistent with the behavior of other actinides during neutralization. It is thus reasonable to estimate that $90 \%$ of the $\mathrm{Np}$ sent to waste will be associated with the sludge and $10 \%$ with the supernate. Salt samples from tank $41 \mathrm{H}$ were analyzed for $\mathrm{Np}-237$, and most or all of the $\mathrm{Np}-237$ was associated with the insoluble solids fraction. This supports the contention that $\mathrm{Np}-237$ is associated with sludge.

$\mathrm{Np}$ in HLW is considered to be $100 \% \mathrm{~Np}-237$, and the total estimated mass is $99.5 \mathrm{~kg}$ (i.e., $70 \mathrm{Ci}$ ).

\section{Americium, Am-241}

Americium is produced from the $\beta$ decay of Pu-241 to Am-241. Relatively pure Am-241 can be recovered by extraction as a decay product from plutonium over a period of years. In the major nuclear material production campaigns at SRS, relatively little americium was produced. The byproduct Am produced from the major reprocessing campaigns is predominantly Am-241. Significant Am-243 was only produced in special campaigns, such as that currently stored in F-Canyon's tank 17.1.

There is little data on its chemical behavior in alkaline waste, but Am is considered to be primarily insoluble. The solubility of Am in neutralized F-Canyon tank 17.1 solution has been determined to be 0.93 $\mathrm{mg} /$, after $99.8 \%$ of the Am had precipitated into a solid phase upon neutralization. Upon mixing the 
neutralized tank 17.1 solution with simulated waste stream solutions (fresh and aged HM and PUREX), the solubility decreased to less than the detection limit of $0.0007 \mathrm{mg} /$. The latter value is consistent with recent concentrations from sample analysis of supernates from waste tanks 38 and 43, where the Am concentrations were less than the detection limits of $0.0003 \mathrm{mg} / 1$ for Am- 241 and $0.007 \mathrm{mg} / \mathrm{f}$ for Am-243. In dissolved tank 41 salt solution, the Am-241 content was found to be less than the detection limit. As with $\mathrm{Pu}$, the accuracy of the reported Am values cannot be confirmed, but only one sample value has exceeded the reported $0.93 \mathrm{mg} / \mathrm{l}$ solubility value.

Am in HLW is considered to be $100 \% \mathrm{Am}-241$, and the total estimated mass is $51 \mathrm{~kg}$ (i.e., $175,000 \mathrm{Ci}$ ).

\section{Actinides in ETF}

In the ETF process, the actinides could result from the tank farm evaporators processing supernate containing some concentrations of actinides (per to their solubilities and inventories previously discussed). Or the ETF actinides could result from the Separations evaporators processing waste from the various fuel and target assemblies. For this report, a "maximum composite" recipe which combines the various sources has been developed (see Table 2, page 34). The tank farm's evaporator overheads recipe was determined by distributing the tank farm inventories of $\mathrm{U} / \mathrm{Pu} / \mathrm{Np} / \mathrm{Am}$ among the various isotopes (in the proportions previously determined to characterize the "supernate contaminated" solid waste ${ }^{5}$ ). The five actinide mixture recipes for the Separations evaporator overheads were taken from earlier calculations done during the DWPF flowsheet development ${ }^{s_{\mathrm{a}}}$. Those calculations gave the curie contents for the various fuel/target assemblies, including: depleted uranium targets used to produce $\mathrm{Pu}-139$; enriched uranium fuel; and Np237 targets used to produce $\mathrm{Pu}-238$ (see Table 2, page 34). For each of the six actinide mixtures, the $\mathrm{U} / \mathrm{Pu} / \mathrm{Np} / \mathrm{Am}$ isotope fractions were tabulated, and a "maximum composite" was selected. For each of the (12) actinide isotopes, this composite selects the largest fraction from the (6) mixtures.

As shown in Table 1 (page 33), each of the "largest fractions" is then multiplied by the ETF concentrate's measured average "gross- $\alpha$ " $\left(1.64 \cdot 10^{-7} \mathrm{Ci} / \mathrm{gal}\right)$ to determine the estimated $\mathrm{Ci} / \mathrm{gal}$ of each actinide. Note that this methodology incorporates a degree of conservatism, because the gross- $\alpha$ is "triple counted" when it is distributed among the (12) largest fractions (they total-up to 3.01). Even with this conservatism, the resultant concentrations of $\mathrm{U} / \mathrm{Pu} / \mathrm{Np} / \mathrm{Am}$ are very low. Table 1 (page 33) shows that the volumes of ETF concentrate required for a waste package to exceed the LAWV's PACs range from $>500,000$ gallons to $>5,000,000$ gallons. Thus so all the actinide isotopes in ETF-1(a) packages will be manifested as zero.

\section{Hazardous Chemicals}

\section{Overview}

A large portion of this sub-section is paraphrased from previous documents ${ }^{6.7}$. The two broad classes of hazardous wastes are called "listed" hazardous waste and "characteristic" hazardous waste. "Listed" hazardous wastes result from using certain chemical products, or originate in particular operations (e.g., producing specific chemicals, or conducting certain physical operations) - these are "listed" in the EPA regulations. "Characteristic" hazardous wastes exhibit certain "characteristics" (e.g., flammability, corrosivity, leaching certain amounts of certain chemicals, etc) -- these are also defined in the EPA regulations.

"Listed" wastes are a concern because the environmental regulations require that any waste "derived" from a listed hazardous waste must also be managed as a hazardous waste, unless the derived waste is "delisted". Thus, a small quantity of listed waste in a LLW package could cause the package to be classified as listed hazardous waste. As discussed in section C.1.b of reference 7, two reviews have concluded that no "listed" hazardous wastes have been identified in the HLW inventory, and there are no process chemicals used in HLW Facilities that would generate a listed waste. One of these reviews was submitted to SCDHEC (1986), and the other was conducted by a DOE "tiger team" (1990). The RCRA 
WSRC-TR-94-0427

Rev: $1(10 / 17 / 94)$

Page 20 of 48

regulations on "listed" waste provide several exemptions (e.g., use of certain reagents in a Lab), and the site Labs are sensitive to proper disposal of un-used reagents.

There is the potential that hazardous LLW could be generated by contact with miscellaneous hazardous chemicals (e.g., paints, cleaners, and lubricants). These chemicals are used in ETF and, if improperly used, have the potential to generate "characteristic" hazardous waste. The primary controls for non-radioactive hazardous chemicals are the Blue Dot Program and the Spill Response procedure. Under the Blue Dot program, containers of hazardous chemicals are marked with a blue dot to identify the chemical as hazardous. The Spill Response procedure is designed to ensure that spills of any chemical are properly managed. If the spilled material is hazardous, the procedure involves the HLW Facilities environmental engineers and the Environmental Protection Department to ensure that any waste resulting from the spill is properly managed.

The ETF wastewater is characteristically hazardous (e.g., it contains leachable mercury, it is strongly acidic or basic), so the main concern is that the solid LLW could become characteristically hazardous. For example, wastewater containing high levels of mercury could come in contact with LLW and deposit enough mercury so that the LLW fails the leach test. However, the concentrations of characteristically hazardous constituents in ETF are so low that a large amount of wastewater (influent or concentrate) would have to be deposited in a waste package before that package would become characteristically hazardous. This is discussed in detail in the following sub-sections.

For the heavy metals present in ETF's wastewater, the EPA test methodology used to determine whether a waste is hazardous is the Toxic Characteristic Leach Procedure (TCLP). This test tries to answer the question "will the (slightly acidic) groundwater percolating through a landfill (etc) become hazardous?". For a solid waste, the test method is: weigh the sample; pulverize it to pass a specified screen size; leach it with a certain volume of a specific acid (for specified time, at a certain temperature, while tumbling at a specific rpm); and then analyze the leachate for the chemicals of interest. Two important aspects of this test method are: only the amount of chemical that leaches out of the sample is relevant (not the total amount present in the sample); and there is a 20:1 "dilution" factor between the weight of sample and the weight of leaching acid.

These aspects of the TCLP test are best demonstrated by example -- let us assume a process liquid stream that contains $5 \mathrm{mg} / \mathrm{L}$ of mercury. By the TCLP definition, for liquid wastes the criteria are applied directly (i.e., the "20:1" and "leachable" factors do not apply), so the liquid is hazardous (since it exceeds mercury's $0.2 \mathrm{mg} / \mathrm{L}$ criteria). However, this is not relevant in determining whether the solid waste (which is somewhat contaminated with this liquid) is hazardous. Let us assume that a 21 " cardboard box weighing $20 \mathrm{lb}(=9,070$ grams) of solid waste is contaminated with $0.3 \mathrm{gal}$ of the process liquid (that has soaked in, or dried out). Thus our box contains $5.68 \mathrm{mg} \mathrm{Hg}(=0.3 \mathrm{gal} * 3.785 \mathrm{~L} / \mathrm{gal} \cdot 5 \mathrm{mg} / \mathrm{L})$, and a $100 \mathrm{gram}$ sample of the solid waste will contain $0.0626 \mathrm{mg} \mathrm{Hg}(=100 \mathrm{~g} /$ sample $* 5.68 \mathrm{mg} / \mathrm{box} / 9070 \mathrm{~g} / \mathrm{box})$. Conservatively assuming that no mercury is immobilized in the solid waste, the $2 \mathrm{~L}$ of leachate $(=100 \mathrm{~g}$ sample $\bullet 20 \bullet 1 \mathrm{ml} / \mathrm{g})$ would contain all the mercury, so the leachate would be $0.031 \mathrm{mg} / \mathrm{L} \mathrm{Hg}(=0.0626 \mathrm{mg} / 2 \mathrm{~L})$. Since this is well below the $0.2 \mathrm{mg} / \mathrm{L} \mathrm{Hg}$ criteria, the solid waste cannot possibly be hazardous.

The calculation demonstrated in the preceding paragraph can also be used to determine the amount of a specified liquid waste that could be present in a solid waste and still pass the TCLP criteria. I.e. (as in the example): "how much of the $5 \mathrm{mg} / \mathrm{L} \mathrm{Hg}$ liquid could be present in the solid waste and still yield leachate $<0.2 \mathrm{mg} / \mathrm{L} \mathrm{Hg}$ ?" (Of course, the liquid must have dried or been adsorbed, it cannot be a "free liquid".) Reversing the previous calculation (for a $100 \mathrm{gm}$ sample of solid waste): the $2 \mathrm{~L}$ of leachate would contain $0.4 \mathrm{mg}$ of $\mathrm{Hg}(=2 \mathrm{~L} * 0.2 \mathrm{mg} / \mathrm{L})$ which would come from $0.08 \mathrm{~L}$ of process liquid $(=0.4 \mathrm{mg} / 5 \mathrm{mg} / \mathrm{L})$. This ratio applies to any amount of solid waste, so a $1000 \mathrm{lb}$ waste package (e.g., a B-25) could contain 95.8 gallons of the $5 \mathrm{mg} / \mathrm{L} \mathrm{Hg}$ process liquid $(=1000 \mathrm{lb} \bullet 453.6 \mathrm{gm} / \mathrm{lb} \bullet 0.08 \mathrm{~L} / 100 \mathrm{gm} / 3.785 \mathrm{~L}$ gal $)$ and still pass the 
WSRC-TR-94-0427

Rev: $1(10 / 17 / 94)$

Page 21 of 48

$0.4 \mathrm{mg}$ of $\mathrm{Hg}(=2 \mathrm{~L} * 0.2 \mathrm{mg} / \mathrm{L})$ which would come from $0.08 \mathrm{~L}$ of process liquid $(=0.4 \mathrm{mg} / 5 \mathrm{mg} / \mathrm{L})$. This ratio applies to any amount of solid waste, so a $1000 \mathrm{lb}$ waste package (e.g., a B-25) could contain 95.8 gallons of the $5 \mathrm{mg} / \mathrm{L} \mathrm{Hg}$ process liquid $(=1000 \mathrm{lb} * 453.6 \mathrm{gm} / \mathrm{lb} * 0.08 \mathrm{~L} / 100 \mathrm{gm} / 3.785 \mathrm{~L} / \mathrm{gal})$ and still pass the $0.2 \mathrm{mg} / \mathrm{L} \mathrm{Hg}$ criteria. Of course, if another process liquid (e.g., ETF's average concentrate) only contained $54 \%$ as much mercury (i.e., $2.72 \mathrm{mg} / \mathrm{L}$ ), then a $1000 \mathrm{lb}$ waste package could contain $1 / 0.54^{\text {th }}$ more of this second process liquid (i.e., $176.2 \mathrm{gal}$ ) and still pass the TCLP criteria. In the following sub-sections, the limiting volume of ETF concentrate that would allow "contact contaminated" waste to meet the TCLP criteria for each of the eight metals is discussed.

By assuming complete leaching, these calculations show the TCLP test's maximum bound. Of course, if the solid adsorbs the chemical and prevents it from leaching, then the actual leachate would contain even less of the chemical. For example, SRTC tests show that GT-73 resin saturated with mercury $(-145 \mathrm{~g} \mathrm{Hg} /$ $570 \mathrm{~g}$ resin) will pass the TCLP test. Following the above math, if all the mercury leached from the GT-73 resin, then the acid would contain $10,100 \mathrm{mg} / \mathrm{L}(=100 \mathrm{~g}$ sample $* 145 \mathrm{~g} \mathrm{Hg} /(145+570) \mathrm{g}$ loaded resin $/ 2 \mathrm{~L}$ acid). However, the actual leachate contains $<0.2 \mathrm{mg} / \mathrm{L}$, so the resin has reduced the leachability by a factor of $>50,700$ and the spent resin is not hazardous. Assuming complete leaching is certainly conservative, and in some cases can demonstrate that the solid waste cannot possibly exceed the hazardous criteria. Otherwise, the actual leachability must be demonstrated by performing the TCLP test.

The EPA regulation limits the allowable leachate concentration of many species (e.g., pesticides and organics), but these are not a concern because they have not been used in the HLW process. Several of the regulation's eight heavy metals do exist in the ETF influent, so all eight will be discussed in subsequent sub-sections of this report. The volume of concentrate required to potentially make a $1000 \mathrm{lb}$ (net) waste package hazardous is discussed in each section, and Table 1 (page 33) also shows the volume required for a $20 \mathrm{lb}$ box. The concentrate volume is proportional to the weight of solid, so it may be "ratio' $\mathrm{d}$ " as desired.

\section{Arsenic, As}

Arsenic is not used in any of the processes that generate HLW (either as raw materials or as alloys used in equipment), but may be present as a fission product or the daughter of a fission product.

At ETF, arsenic has been monitored regularly in the concentrate, and Chart 12 (page 48) shows the $>205$ analyses. To date, all analyses have been " $<10 \mathrm{mg} / \mathrm{L}$ " (those are charted as "10"). To exceed the $5 \mathrm{mg} / \mathrm{L}$ TCLP limit, a $1000 \mathrm{lb}$ (net weight) B-25 box would have to contain $>1150$ gal of concentrate (at $10 \mathrm{mg} / \mathrm{L}$ ), so arsenic will not cause the ETF-1(a) waste stream to be hazardous. This volume incorporates the 20:1 factor involved in the TCLP test, and assumes the arsenic leaches completely.

\section{Barium, Ba}

Barium is not used in any of the processes that generate HLW (either as raw materials or as alloys used in equipment), but it is present as the decay daughter of Cs-137.

At ETF, barium has been monitored regularly in the concentrate, and Chart 12 (page 48) shows the $>205$ analyses. To date, all but one analysis has been " $<10 \mathrm{mg} / \mathrm{L}$ " (those are charted and averaged as " $10 "$ "). To exceed the $100 \mathrm{mg} / \mathrm{L}$ TCLP limit, a $1000 \mathrm{lb}$ (net weight) B-25 box would have to contain $>23,900$ gallons of average concentrate (at $10 \mathrm{mg} / \mathrm{L}$ ), so barium will not cause the ETF-1 (a) waste stream to be hazardous. This volume incorporates the 20:1 factor involved in the TCLP test, and assumes the barium leaches completely. 
WSRC-TR-94-0427

Rev: 1 (10/17/94)

Page 22 of 48

\section{Cadmium, Cd}

Cadmium is not used in any of the processes (either as raw materials or as alloys used in equipment) that generate HLW, but may be present as a fission product or the daughter of a fission product.

At ETF, cadmium has been monitored regularly in the concentrate, and Chart 12 (page 48) shows the $>205$ analyses. To date, all analyses have been " $<10 \mathrm{mg} / \mathrm{L}$ " (those are charted and averaged as " 10 "). To exceed the $1 \mathrm{mg} / \mathrm{L}$ TCLP limit, a $1000 \mathrm{lb}$ (net weight) B-25 box would have to contain $>240$ gallons of concentrate (at $10 \mathrm{mg} / \mathrm{L}$ ), so cadmium will not cause the ETF-1 (a) waste stream to be hazardous. This volume incorporates the 20:1 factor involved in the TCLP test, and assumes the cadmium leaches completely.

\section{Chromium, $\mathbf{C r}$}

Chromium is present in HLW from several sources. In the canyons, dissolution of stainless steel clad fuel tubes and corrosion of stainless steel vessels introduces quantities of $\mathrm{Cr}$ into the waste. Chromate solutions have been used in the past for target cleaning in the RBOF/RRF. Within the HLW tanks, some of the cooling coils have developed leaks, allowing chromate cooling water into the waste inventory. At the high hydroxide concentration of the fresh waste stream and as maintained in the waste tanks, chromium is present as the $\mathrm{CrO}_{4}{ }^{\circ}$ ion.

At ETF, chromium has been monitored regularly in the influent and concentrate, and Chart 11 (page 47) shows the $>1705$ and $>215$ analyses (respectively). To date, most of the influent and concentrate analyses have been " $<1 \mathrm{mg} / \mathrm{L}$ " and " $<10 \mathrm{mg} / \mathrm{L}$ " (those are charted and averaged as " 1 " and " 10 " respectively). The influent values exhibit more "noise spikes" than the concentrate values (the spikes get "dampened" out by the ETF process inventory). Since most of the values are less than the lab's reporting limits, the $\sim 80 \mathrm{x}$ factor between influent and concentrate results is not clearly visible. To exceed the $5 \mathrm{mg} / \mathrm{L}$ TCLP limit, a $1000 \mathrm{lb}$ (net weight) B-25 box would have to contain $>1030$ gal of average concentrate (at $11.6 \mathrm{mg} / \mathrm{L}$ ), so chromium will not cause the ETF-1(a) waste stream to be hazardous. This volume incorporates the 20:1 factor involved in the TCLP test, and assumes the chromium leaches completely.

Lead, $\mathbf{P b}$

Lead present in high level waste originated as a lubricant used in the extrusion of fuel/target assemblies, and it may be present as the final decay daughter of uranium.

At ETF, lead has been monitored regularly in the concentrate, and Chart 12 (page 48) shows the $>205$ analyses. To date, all but 7 analyses have been " $<10 \mathrm{mg} / \mathrm{L}$ " (those are charted and averaged as " 10 "). To exceed the $5 \mathrm{mg} / \mathrm{L}$ TCLP limit, a $1000 \mathrm{lb}$ (net weight) B-25 box would have to contain $>1180$ gal of average concentrate (at $10.2 \mathrm{mg} / \mathrm{L}$ ), so lead will not cause the ETF-1(a) waste stream to be hazardous. This volume incorporates the 20:1 factor involved in the TCLP test, and assumes the lead leaches completely.

\section{Mercury, $\mathbf{H g}$}

Mercury is used in the H-Canyon process as a catalyst to aid in the dissolution of the aluminum cladding of fuel tubes. Upon addition of $\mathrm{NaOH}$ to the acidic waste stream, the $\mathrm{Hg}$ precipitates as the extremely insoluble $\mathrm{HgO}$, mixing in with the remaining components of the sludge layer. Due to the high free hydroxide concentration in the supernate $(>1 \mathrm{M})$, a small fraction of the mercury remains soluble as the sodium salt of the $\mathrm{HgO}(\mathrm{OH})^{-}$ion. In the tank farm evaporators, part of the soluble mercury is reduced to mercury metal and volatilized into the overheads stream. Part of the condensed mercury is physically separated, and the remainder goes to ETF when the overheads are discharged.

At ETF, mercury has been monitored regularly in the influent and concentrate, and Chart 10 (page 46) shows the $>1755$ and $>230$ analyses (respectively). Analyses values reported as " $<X "$ are charted as " $X "$ 
WSRC-TR-94-0427

Rev: $1(10 / 17 / 94)$

Page 23 of 48

(prior to $11 / 89$ the concentrate analysis had a $10 \mathrm{mg} / \mathrm{L}$ reporting limit, so those 105 analyses is not included in the average). As expected, the concentrate values are not the full $\sim 80 \mathrm{x}$ higher than the influent values -- reflecting the net effect of ETF's $\sim 80: 1$ volume reduction combined with the amount of mercury adsorbed on the $\mathrm{Hg}$ removal resin. To exceed the $0.2 \mathrm{mg} / \mathrm{L}$ TCLP limit, a $1000 \mathrm{lb}$ (net weight) B-25 box would have to contain $>176$ gal of average concentrate (the $>125$ analyses average $2.72 \mathrm{mg} / \mathrm{L}$ ), so mercury will not cause the ETF-1 (a) waste stream to be hazardous. This volume incorporates the 20:1 factor involved in the TCLP test, and assumes the mercury leaches completely.

Selenium, Se

Selenium is not used in any of the processes (either as raw materials or as alloys used in equipment) that generate $H L W$, but it is present as a fission product (see Se-79 above).

At ETF, selenium has been monitored regularly in the concentrate, and Chart 12 (page 48) shows the $>205$ analyses. To date, all but one analysis has been " $<4 \mathrm{mg} / \mathrm{L}$ " (those are charted and averaged as " 4 "). To exceed the $1 \mathrm{mg} / \mathrm{L}$ TCLP limit, a $1000 \mathrm{lb}$ (net weight) B-25 box would have to contain $>595$ gallons of average concentrate (at $4 \mathrm{mg} / \mathrm{L}$ ), so selenium will not cause the ETF-l (a) waste stream to be hazardous. This volume incorporates the 20:1 factor involved in the TCLP test, and assumes the selenium leaches completely.

Silver, Ag

Silver originates as a fission product, and non-radioactive silver has been transferred in the past to the waste tanks from the flushing of beds of silver-coated Beryl saddles used to trap iodine in the canyons. When the canyon waste is neutralized with hydroxide, the silver precipitates as insoluble $\operatorname{Ag}_{2} \mathrm{O}$, with a small fraction remaining soluble as $\mathrm{NaAg}(\mathrm{OH})_{2}$.

At ETF, silver has been monitored regularly in the concentrate, and Chart 12 (page 48) shows the $>205$ analyses. To date, all but 3 analyses have been " $<10 \mathrm{mg} / \mathrm{L}$ " (those are charted as "10"). To exceed the 10 $\mathrm{mg} / \mathrm{L}$ TCLP limit, a $1000 \mathrm{lb}$ (net weight) B-25 box would have to contain $>1178$ gal of average concentrate (at $10.2 \mathrm{mg} / \mathrm{L}$ ), so silver will not cause the ETF-l(a) waste stream to be hazardous. This volume incorporates the 20:1 factor involved in the TCLP test, and assumes the silver leaches completely.

\section{CHARACTERIZATION OF THEADSORBENT WASTE STREAMS}

The previous section developed the characterization for ETF solid waste (i.e., waste stream ETF-1(a)) that is "contact contaminated" with the same radionuclide/chemical "recipe" as exists in the ETF process wastewater. This section develops the characterization of the four solid wastes where various contaminants can be preferentially adsorbed, thus the contamination is not necessarily represented by the wastewater's composition.

Each of the subsequent sub-sections discusses the radionuclides detected in recent samples of these solid wastes ${ }^{8}$. For most of the remaining radionuclides, comparing their detection limits to the LAWV PACs demonstrates that they cannot exceed the PAC, see Table 4 (page 36). The lab analysis was not "sensitive" enough to confirm the absence of I-129 (and to lesser degrees, U-233 and Sn-126).

\section{Basin Waste, Including Sediment -- "ETF-1(b)"}

After water has been diverted to one of the ETF basins, it is sampled to confirm that it meets the clean discharge limits, and then it is normally pumped to the NPDES outfall. In the basin influent, slight amounts of activity can be adsorbed on dirt particles (as opposed to being dissolved in the water), and the larger suspended particles typically settle out in the large basins. Periodically, the basins are emptied and any accumulated sediment is removed. The sediment may be found to be slightly contaminated, even when 
WSRC-TR-94-0427

Rev: $1(10 / 17 / 94)$

Page 24 of 48

no "real" diversions of contaminated water have occurred. A "real" diversion is defined as occurring when the basin water must be treated before it can be discharged. Waste stream ETF-1(b) consists of normal job waste (e.g., gloves, broken equipment, etc) that is generated throughout the year, plus the sediment that is removed periodically.

Table 3 (page 35) gives the available sample data on basin sediment. One sample has been analyzed by the ADS lab's TCLP method. The leachate metal concentrations were considerably below the RCRA limits, so the basin waste was not hazardous. Two sediment samples have been analyzed ${ }^{11}$ for their radionuclide content. In both cases, $\mathrm{Cs}-137$ was so low $(1.1-1.8 \mathrm{nCi} / \mathrm{gm})$ that a waste package would have to contain $>930,000$ pounds of sediment to exceed the $0.76 \mathrm{Ci}$ PAC. At these concentrations, a B-12 box that is predominantly sediment could exceed the MRQ, but a package of job waste contaminated with sediment would not. Since one radionuclide must be listed, the basin waste package manifests will list Cs-137 (based on the field radiation survey and the dose-to-curie conversion).

The basin sediment characterization shows that it will only contain Cs-137, so it is "lumped" into the general designation ETF-1. As such, the sediment does not need to be segregated from general treatment plant waste, and any quantity can be included in any ETF-1 waste package.

Water that is diverted to the ETF basins could contain a wide variety of radionuclides. Historically, waste tank supernate has been the most likely source because that was the only material routinely moved around the tank farm (e.g., feeding the evaporators). Now that waste removal and waste processing operations are becoming more common, the range of likely compositions is widening (e.g., sludge handled in ESP). The curie content of a "real" contaminated diversion could vary widely, and the actual radionuclide "recipe" will have to be determined "after the fact". In ETF's 5.5 year operating history, only one "real" diversion has occurred, although ETF's original design basis anticipated a frequency of about once per year.

Regardless of the frequency, when the water is contaminated, it can be sent to the ETF treatment plant, and (once HDB-8 becomes operational) the water could be sent to the tank farms, or alternative treatment could be provided (e.g., Chem-Nuclear treated the $8 / 89$ diversion). In this case, the particular radionuclide distribution and amounts adsorbed in the sediment may be based either on the characterization of the source of the contamination, or on sample analyses. ETF's operating procedures need to require that the solid waste resulting from each "real" diversion be characterized. This may be accomplished either by adding a "stop" point in the relevant procedures (i.e., to require an approved recovery plan prior to proceeding), or a sampling plan could be approved in advance. Regardless, the "non-routine" waste that could result from a "real" diversion is outside the scope of the "routine" characterization of waste stream ETF-1(b). Note that a "real" diversion could impact the characterization of waste streams beyond ETF-1(b), e.g., if the diverted water were treated at the ETF treatment plant, then the composition of streams ETF-1(a), ETF-2, or ETF-3 could also be affected.

\section{Ion Exchange Resin - "ETF-1(c)"}

The ion exchange columns are used until the routine samples of their liquid effluent indicates that the HPK-25 resin's capacity to adsorb Cs- 137 has been reached. The spent resin is regenerated in-place, using $\mathrm{NaNO}_{3}$ solution to elute the Cs-137. When the resin is replaced (the initial batch of resin installed for ETF's $11 / 88$ startup is still performing), it will be sluiced from the vessel, dewatered, and packaged in B-12 boxes.

Exothermic chemical reactions can result when organic ion exchange resins (particularly anion resins) are contacted with strong nitrate solutions (particularly nitric acid), especially after the resin has dried (similar to auto-ignition of oily rags). However, the HPK-25 resin is a cation resin, it is regenerated with 2 molar sodium nitrate at neutral $\mathrm{pH}$ (not nitric acid), and its wastewater feed has a low nitrate concentration $(<200$ $\mathrm{mg} / \mathrm{L}$ ). There is no concern about exothermic reactions when the spent HPK-25 resin is sent to the EAV. 
Table 3 (page 35) gives the available sample data on HPK-25 ion exchange resin. One sample has been analyzed by the ADS lab's TCLP method. The leachate metal concentrations were considerably below the RCRA limits, so the resin was not hazardous. Two resin samples have been analyzed " for their radionuclide content, and only $\mathrm{Cs}-137$ was detected. The $\mathrm{Cs}-137$ was so low $(0.53-2.1 \mathrm{nCi} / \mathrm{gm})$ that a waste package would have to contain over 790,000 pounds of resin to exceed the $0.76 \mathrm{Ci} \mathrm{PAC}$. However, a waste package containing over $790 \mathrm{lb}$ of resin would exceed the MRQ, so the ETF-1(c) waste package manifests will list Cs-137 (based on the field radiation survey and the dose-to-curie conversion).

The HPK-25 resin characterization shows that it will only contain Cs-137, so it is "lumped" into the general designation ETF-1. As such, the resin does not need to be segregated from general treatment plant waste (discussed as ETF-1 (a) in this report), and any quantity can be included in any ETF-1 waste package.

\section{Mercury Removal Resin -- "ETF-2"}

The mercury removal column's (liquid) effluent is sampled regularly to ensure that the resin's capacity to adsorb mercury has not been reached. When the spent GT-73 resin is replaced, it will be dewatered and packaged in B-12 boxes. Smaller quantities of used resin (which result from periodic backflushing of the columns) may be packaged in standard 55-gallon drums. Historically, ETF has generated $\sim 2$ drums per year of this resin, and it would not be desirable to "hold" the waste resin for 3 years (i.e., to fill a B-12).

Exothermic chemical reactions can result when organic ion exchange resins (particularly anion resins) are contacted with strong nitrate solutions (particularly nitric acid), especially after the resin has dried (similar to auto-ignition of oily rags). The GT-73 resin is a cation resin, it is not regenerated with nitric acid, and its wastewater feed contains a low nitrate concentration $(200-2000 \mathrm{mg} / \mathrm{L})$. There is no concern about exothermic reactions when the spent GT-73 resin is sent to the EAV.

Table 3 (page 35) gives the available sample data on GT-73 resin. Two samples have been analyzed by the TCLP test: one by an offsite certified lab, the other by the ADS lab's TCLP method. In both cases, the leachate metal concentrations were considerably below the RCRA limits, so the spent resin is not hazardous. Three resin samples have been analyzed ${ }^{11}$ for radionuclides, and the only ones found were $\mathrm{Co}-60, \mathrm{Cs}-137$ and $\mathrm{Am}-241$. The $\mathrm{Co}-60$ was low enough $(0.129-0.168 \mathrm{nCi} / \mathrm{gm})$ that a waste package would have to contain over 301 million pounds of resin to exceed the $23 \mathrm{Ci} \mathrm{PAC}$, so no waste package could exceed the MRQ. The Cs-137 was so low (1.2-3.4 nCi/gm) that a waste package would have to contain over 490,000 pounds of resin to exceed the $0.76 \mathrm{Ci}$ PAC. The Am-241 was also low enough $(<1$ $\mathrm{nCi} / \mathrm{gm}$ ) that a waste package would have to contain over $208,000 \mathrm{lb}$ of resin to exceed the $0.091 \mathrm{Ci}$ PAC. Since a waste package containing $208-490$ pounds of resin would exceed the MRQs, the ETF-2 manifests will list Cs-137 and Am-241. Cs-137 will be based on either the radiation survey and dose-to-curie conversion, or on lab analysis of a resin sample. Am-241 will be based on $0.3 \mathrm{Ci}_{\mathrm{Am}-241} / \mathrm{Ci}_{\mathrm{Cs}_{\text {-137 }} \text { (the average }}$ of the three samples).

SRTC has conducted lab experiments ${ }^{9,10}$ where GT-73 resin was loaded with various heavy metals and subjected to the RCRA leach test. In each case, resin loaded (individually) with mercury, chromium ${ }^{3+}$, lead, and silver passed the TCLP test. For example, resin that was loaded to $>20 \mathrm{wt} \%$ mercury (145 gm $\mathrm{Hg}$, on resin that originally weighed $570 \mathrm{gm}$ ) generated leachate that was below the RCRA $0.2 \mathrm{mg} / \mathrm{L}$ criteria, so the spent resin was not hazardous.

The GT-73 resin characterization shows that it will contain Am-241 in addition to Cs-137, so it is designated ETF-2. While large quantities of resin are segregated from the general treatment plant waste, practical operating flexibility demands that an incidental quantity $(\leq 20 \mathrm{lb})$ may occasionally be added to a B- 25 box of ETF-1 waste. As shown above, $>208 \mathrm{lb}$ would be required to exceed the LAWV MRQ, and the additional factor of 10 is deemed a suitable margin to allow convenient disposal of an incidental 
quantity of GT-73 resin. This type of incidental quantity could result from cleaning up a spill, or from sampling the resin beds.

\section{Activated Carbon -- "ETF-3"}

In the ETF process, granular activated carbon is utilized in large vessels ( $\sim 10^{\prime}$ diameter and $\sim 20^{\prime}$ tall). Each vessel is used until routine samples of its effluent indicate that the carbon has reached its full capacity to remove dissolved organics. Depending on the organic concentration in the ETF influent, a vessel remains in service for at least several months (some have lasted for over a year). When its capacity has been consumed, all free water is drained from the vessel, adsorbent is added (via an internal device similar to a screened well point), and the vessel is readied for transport to the EAV. (Note: Replacing the process vessels is cheaper than facilities to transfer the spent carbon to separate disposal containers, so the 1/4" thick stainless steel ASME code process vessels serve both purposes.)

For the ETF-3 waste stream, the $-66,000 \mathrm{lb}$ waste package consists of: the vessel $(-21,000 \mathrm{lb}$ empty); the activated carbon (originally $\sim 23,000 \mathrm{lb}$ dry); the organics removed from the ETF influent $(-9,200 \mathrm{lb}$, at 0.4 $\mathrm{lb}$ organic per $\mathrm{lb}$ of carbon); and the adsorbent $(-400 \mathrm{lb})$. The remaining $\sim 12,400 \mathrm{lb}$ is moisture (primarily trapped in the pores of the carbon granules, and comprising the bodies of bacteria in the carbon bed) which could contain tritium equivalent to 1490 gallons of ETF wastewater. As discussed above and shown in Chart 7 (page 43), tritium in ETF has averaged $0.0000629 \mathrm{Ci} /$ gal, so the average spent carbon vessel would contain $-0.09 \mathrm{Ci}$. These values are well below the $10 \mathrm{Ci}$ PAC for tritium in the LAWV, but tritium will be listed on the ETF-3 manifests since it will exceed the 0.01 Ci MRQ. The tritium content will be based on the "weight gain" of the vessel (as in the example above) and the tritium content of ETF wastewater when the vessel was last in service. Due to their weight and size, spent carbon vessels may actually go to the Intermediate Level Vault (ILV) which has the same tritium PAC (10 Ci) as the LAWV.

Table 3 (page 35) gives the available sample data on activated carbon. Two samples have been analyzed by the TCLP test: one by an offsite certified lab, the other by the ADS lab's TCLP method. In both cases the leachate metal concentrations met the RCRA limits by considerable margins, so the spent carbon is not hazardous. Three carbon samples have been analyzed " for radionuclides, and the only radionuclides found were Cs-137 (in all samples) and Am-24l (in one sample). The Cs-137 was so low (0.22-0.36 nCi/gm) that a waste package would have to contain over 4.6 million pounds of carbon to exceed the $0.76 \mathrm{Ci} \mathrm{PAC}$. The single Am-241 result was also very low $(0.53 \mathrm{nCi} / \mathrm{gm})$ and a waste package would have to contain over $378,000 \mathrm{lb}$ of carbon to exceed the $0.091 \mathrm{Ci}$ PAC. Since a vessel containing $23,000 \mathrm{lb}$ of spent carbon would exceed the MRQs, the ETF-3 manifests will list Cs-137 and Am-241 (in addition to tritium). Cs-137 will be based on either the radiation survey and dose-to-curie conversion, or on lab analysis of a carbon sample. Am-241 will be based on $1.5 \mathrm{Ci}_{\mathrm{Am}_{2} 241} / \mathrm{Ci}_{\mathrm{Cs}-137}$ (per the one sample that found $\mathrm{Am}-241$ ).

The spent carbon's characterization shows that it may contain Am-241 in addition to Cs-137, and the waste package is unique, so it is designated ETF-3. While large quantities of carbon are segregated from the general treatment plant waste, practical operating flexibility demands that an incidental quantity $(\leq 35$ lb) may occasionally be added to a B-25 box of ETF-1 waste. As shown above, $>378 \mathrm{lb}$ would be required to exceed the LAWV MRQ, and an additional factor of 10 is deemed a suitable margin to allow convenient disposal of an incidental quantity of carbon. This type of incidental quantity could result from cleaning up a spill, or from sampling the carbon beds.

\section{MISCELLANEOUS ACCEPTANCE CRITERIA}

As described in Reference 2, waste packages contaminated with HLW supernate will meet the WAC criteria on:

- criticality

- TRU

- heat content

- Class $\mathrm{C}$ waste 
As this report has demonstrated, the radioactivity of the ETF's process solutions is hundreds of thousands of fold less concentrated than that of the HLW supernate, so it is apparent that ETF's solid waste will also meet these criteria. For example, several nuclear safety isotopes are expressed as the total "Fissile Gram Equivalent U-235" (FGE) and are limited to either 50 grams (non-compactable), 2 grams (compactable), or 1 gram (non-standard packages). As shown in Table 1 (page 33), the FGE content of ETF's concentrate is $1.36 \cdot 10^{-4} \mathrm{gm} / \mathrm{gallon}$, so a package of ETF-1 (a) waste would have to contain the activity from $>367,000$ gallons in order to exceed the WAC value ( 50 gram). Similarly, as shown in Table 3 (page 35), the samples of wastes ETF-1(b), ETF-1(c), ETF-2, and ETF-3 did not detect any of the fissile isotopes. Thus all ETF waste packages will meet the FGE requirement.

Beyond the radionuclide and hazardous chemical PACs already discussed in this report, the WACs also limit several general chemical and physical characteristics of waste accepted by the Solid Waste Facilities. These criteria have been addressed in a generic report ${ }^{7}$ that covers all HLW facilities (including ETF). One of these criteria has already been elaborated upon, and three others deserve elaboration:

- Reactive Chemicals:

- Detonations, Explosions, and Reactions

- Reactions with Water

- Pyrophoric Wastes

- Generation of Toxic Gases

- Generation of Combustible Gases

- Chelating and Complexing Agents ... see below ...

- Organics ... see below ...

- Organic Nitrated Resins ... see ETF-1(c) and ETF-2 above ...

- Pathogens, Infectious Wastes, or Etiologic Agents

- Tritium Off-Gassing

- Incompatible Wastes or Wastes That Could Degrade Container ... see below ...

- Cyanide Wastes and Sulfide-Bearing Waste

\section{Chelating and Complexing Agents}

Oxalate is the only chelating or complexing agent that occurs in the wastewater generating processes. The oxalate comes from oxalic acid that is used as a decontamination agent in various facilities, including the tank farms, 299-H, and ETF (e.g., to clean the ceramic filters). Oxalate solubility depends on the solution's sodium content, since the oxalate will precipitate as sodium oxalate. The solubility ranges from $-6 \mathrm{wt} \%$ in water, to $-0.8 \mathrm{wt} \%$ in 1.5 molar sodium (and would be even less in the $\sim 5$ molar ETF concentrate). However, the amounts of solution that will contaminate a solid waste package will be low enough so that the waste package will not exceed $1 \%$ oxalate. For example, $1 / 2$ gallon of $2 \mathrm{wt} \%$ oxalic acid in a B-25 box with 1000 pounds of waste would only yield $0.0083 \%$ oxalate.

\section{$\underline{\text { Organics }}$}

Several of the WACs contain criteria involving organics, specifically: petroleum hydrocarbons are limited to $100 \mathrm{ppm}$; benzene, toluene, ethyl benzene, and xylene are limited to $10 \mathrm{ppm}$; oils are acceptable only in trace quantities; and PCBs are limited to $50 \mathrm{ppm}$. ETF's activated carbon system removes the $<100 \mathrm{ppm}$ of tributyl phosphate and n-dodecane (used in the Separations process) from the wastewater influent. The organics limited by the WACs are most likely to result from a spill of diesel fuel or gasoline (which could exceed the hydrocarbon or benzene limit). Such spill cleanup activities are controlled by the Spill Response Procedure, and any resulting solid waste would be characterized and handled appropriately. 
WSRC-TR-94-0427

Rev: $1(10 / 17 / 94)$

Page 28 of 48

\section{Incompatible Wastes or Wastes That Could Degrade Container}

Either the waste containers (cardboard or carbon steel) or their liners and bags (plastic) could be degraded by acidic liquids, e.g. ETF influent wastewater (frequently $<3 \mathrm{pH})$, oxalic acid cleaning solution $(\sim 2 \mathrm{wt} \%$ ), or nitric acid (1-64 wt\%). Preparations for maintenance activities on process equipment containing such materials would include flushing with water. A spill of such acidic materials would be diluted with a large quantity of water and routed through the ETF process. Solid waste that has contacted remnants of such acidic liquids does not pose an unacceptable hazard to the waste container.

\section{EUTURE,CONDITIONS}

Wastewater treated at ETF comes from several sources in Separations and High Level Waste. Occasionally, the generators consider process changes that could modify their wastewater's composition, and thereby effect the ETF treatment process, or the composition of ETF's solid waste. Likewise, new feed streams are occasionally proposed for treatment at the ETF. The ETF Engineering group evaluates these changes for potential impacts. In the past, some of these evaluations have resulted in treatability studies by SRTC and permit modifications by SCDHEC, and they have always included assessing the impact on ETF's waste streams. In the future, these evaluations will continue to confirm that ETF's solid waste streams will not be adversely affected -- prior to approving the change. As examples, three recent or proposed changes will be briefly discussed:

- Tritium analyses are conducted by the ETF Lab and the 232-H Lab, utilizing a liquid scintillation fluid (Opti-Fluor ${ }^{\mathrm{TM}}$ ) which is a blend of long chain alkylbenzenes, scintillators (PPO and bis-MSB), and tributyl phosphate (TBP, also present in Separation's solvent). "Used" fluid ends up in ETF's influent wastewater, where the organics are removed by the activated carbon ETF-3. The fluid does not contain RCRA listed chemicals, and its $150^{\circ} \mathrm{C}$ flash point means that it is not RCRA hazardous. The D-area lab also uses the same fluid, and has proposed that ETF increase the amount received, such that D-area could gradually "work-off" their accumulation.

- When DWPF begins operating, a recycle stream containing traces of benzene $(<10 \mathrm{mg} / \mathrm{L})$ and small quantities of other species (e.g., $300-3000 \mathrm{mg} / \mathrm{L}$ formate and $\sim 800 \mathrm{mg} / \mathrm{L}$ phenol) will be returned to the tank farm evaporator system. Some of the organic may volatilize into the overheads and go to ETF, so the spent activated carbon (waste stream ETF-3) has been tested to confirm it removes the relevant species ("Treating DWPF [Cold Run] Recycle at the ETF", WSRC-RP-93-0497 rev-1, M. R. Poirier, 04/02/93). During DWPF's current cold chemical runs, this recycle stream is being trucked directly to the ETF.

- The Environmental Restoration Division has proposed that ETF treat 100-250 Kgal/yr of "purge water" (from sampling of groundwater monitoring wells). This water will contain $<2$ to $10 \mathrm{mg} / \mathrm{L}$ (each) of several organics, primarily tetrachloroethylene, trichloroethylene, methylethylketone, and acetone. The total organic content of ETF's influent would increase by $<2 \mathrm{mg} / \mathrm{L}$, and the organics will be removed by the activated carbon ETF-3. The purge water from some of the wells is categorized as "listed" waste due to high levels of certain organics, so that purge water is not proposed for treatment by ETF. The low level organics are too dilute for any flammability concern and ETF has been determined to be a suitable treatment process ("Treating Environmental Restoration Purge Water at the ETF", WSRC-RP-94-0632, M. R. Poirier and A. W. Wiggins, $6 / 28 / 94$ ). This proposal is being submitted to SCDHEC for approval and is anticipated to commence $\sim 4 / 95$.

Evaluating process and wastewater changes (like these) is a routine matter and will continue to consider the potential impact on ETF's resultant solid waste. Sample results that potentially invalidate this waste characterization will be reported to the Solid Waste Characterization Board. 
WSRC-TR-94-0427

Rev: 1 (10/17/94)

Page 29 of 48

\section{CONCLUSIONS\& RECOMMENDATIONS}

This report demonstrates that ETF's solid waste is suitable for disposal at the EAV, and that the compositions will meet the WAC requirements. As tabulated on page 5, Cs-137 will be listed on all of ETF's waste package manifests (based either on a dose-to-curie conversion process, or on a sample analysis), and some packages will also manifest tritium and Am-241.

ETF needs to continue the practice of evaluating the potential impact on solid waste characterizations whenever treatment of a new or revised wastewater stream is considered (whether a "one time" or continuous receipt).

With ETF's low background radiation rates and the low package inventories of Cs-137, ETF would be a prime candidate for a more sensitive exposure rate meter -- this could avoid "artificially" inflating the package's $\mathrm{Ci}$ contents.

If the proposal to allow an incidental quantity $-\leq 1 / 10^{\text {th }}$ of the LAWV MRQ (i.e., $\leq 20 \mathrm{lb}$ of GT-73 resin, or $\leq 35 \mathrm{lb}$ of activated carbon) -- in an occasional package of ETF-1 waste is not accepted, then a deviation request should be pursued.

The dose-to-curie conversions for ETF-2 resin in 55 gal resin drums and ETF-3 carbon vessels need to be developed, unless the isotope inventories are manifested based on sample analysis.

The ETF-3 carbon vessels will be a "non-standard disposal package", for which proper approval need to be developed.

ETF's operating procedures need to require that the solid wastes resulting from each "real" diversion of cooling water or storm water be characterized. 
WSRC-TR-94-0427

Rev: $1(10 / 17 / 94)$

Page 30 of 48

\section{References}

1. "SRS Waste Acceptance Criteria Manual", the WSRC-1S manual, specifically:

- the 253-H compactor PAC, per table 1 of procedure WAC 3.04, rev-1, 5/21/94), and

- the LAWV PAC, per table 2 of procedure WAC 3.10, rev-1, 5/21/94).

2. "High Level Waste Characterization in Support of Low Level Waste Certification (U)", M. C. Chandler/et.al., WSRC-TR-94-0290 rev-2, August 22, 1994.

3. "Waste Characterization of Activation Product Radionuclides in High Level Waste Supernate (U)", C. E. Bess, WSRC-TR-94-0291, June 30, 1994.

3a. "Update of Chemical and Radiochemical Composition of Decontaminated Soluble Waste From the Precipitation Process", J. R. Fowler, DPST-82-759, August 6, 1982.

4. "Assessment of Fission Product Content of High Level Liquid Waste Supernate on E-Area Vault Package Criteria (U)", D. F. Brown, WSRC-TR-94-0292, June 30, 1994".

5. "Characterization of Uranium, Plutonium, Neptunium, and Americium in HLW Supernate for LLW Certification (U)", J. S. Clemmons, WSRC-TR-94-0296, June 30, 1994.

5a. "Preliminary Technical Data Summary - DWPF Stage 2", DPSTD-80-39 rev-0, December, 1980 (specifically calculations by J. R. Chandler, included as Appendix 13.6 (note that this information was not included in the later/current version, which is rev-2))

6. "Characterization of Hazardous Constituents in HLW Supernate and Implications for Solid LLW Generation (U)”, G. K. Georgeton, WSRC-TR-94-0297, June 22, 1994.

7. "Chapter VI -- Physical/Chemical Characterization of Low Level Waste Generated in High Level Waste Facilities (U)", P. D. d'Entremont, WSRC-TR-94-0393, August 15, 1994.

8. "High Level Waste -- Effluent Treatment Facility - Waste Certification Plan", P. M. Stapf and P. M. Allen, HLW-SUP-94-0285 rev 0, September 19, 1994.

9. "TCLP Test Results for $\mathrm{Hg}, \mathrm{Cr}(\mathrm{III})$, and $\mathrm{Pb}$ on GT-73 Cation Exchange Resin", J. P. Bibler, DPST-87-811, November 13, 1975.

10. "Toxic Component Leach Test (TCLP) for Silver on GT-73 Cation Exchange Resin", J. P. Bibler, WSRC-TR-91-061, January 29, 1991.

11. "Analyses of Hg Removal Resin and Basin Mud Samples", R. C. Hochel, SRT-ADS-93-0338, July 9, 1993. Regardless of the title, his report includes the activated carbon and HPK-25 resin analyses. Per his 4/30/93 and 5/5/93 Emails, the GT-73 results used in this report have been multiplied by 0.3 .

12. "Tank Farm Sampling and Analysis Plan", P. D. d'Entremont/etal, WSRC-TR-94-0304, draft-C of rev-0 dated $07 / 14 / 94$. 


\section{F/H ETF Process Flow Diagram \& Waste Generation Sources}

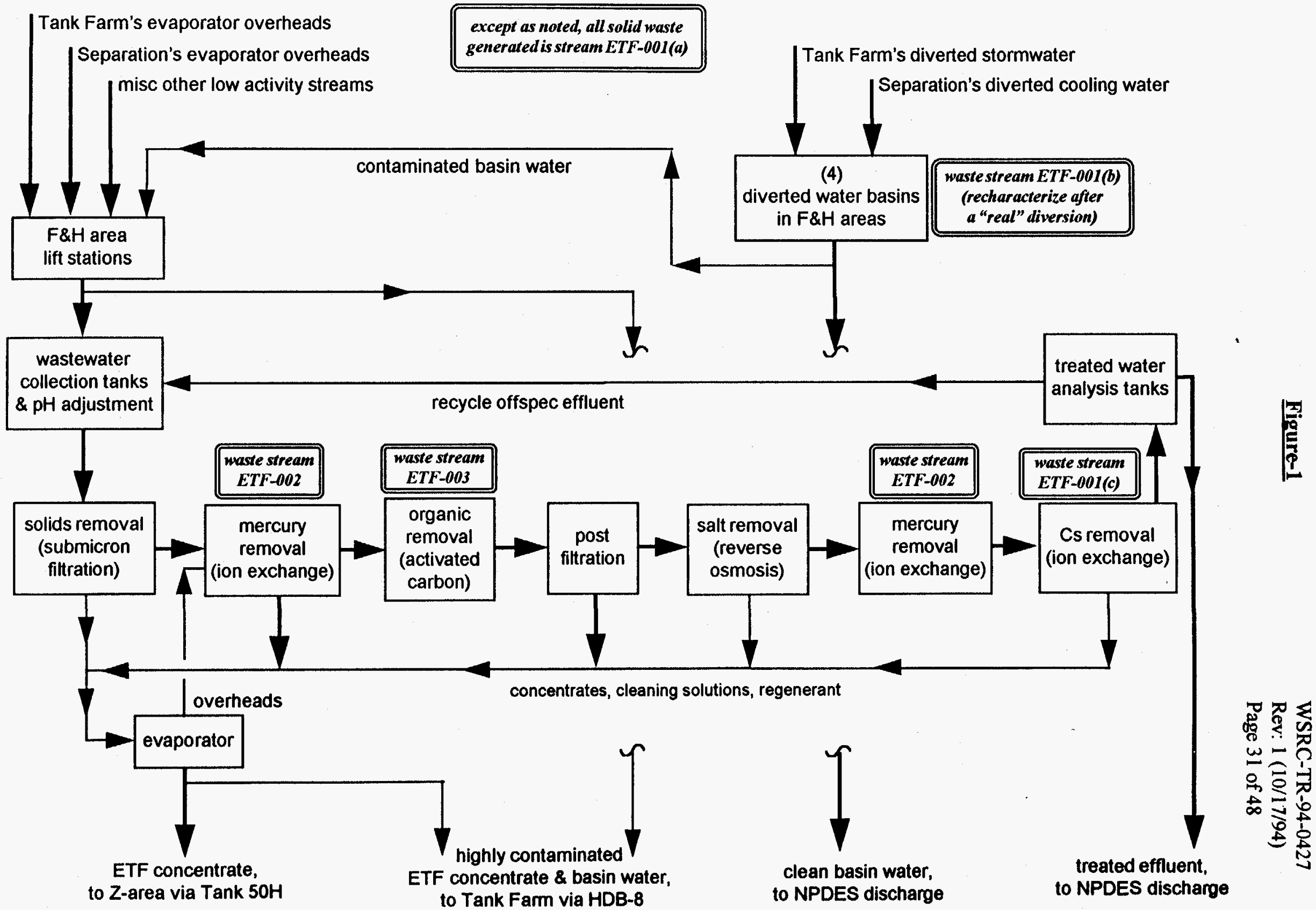




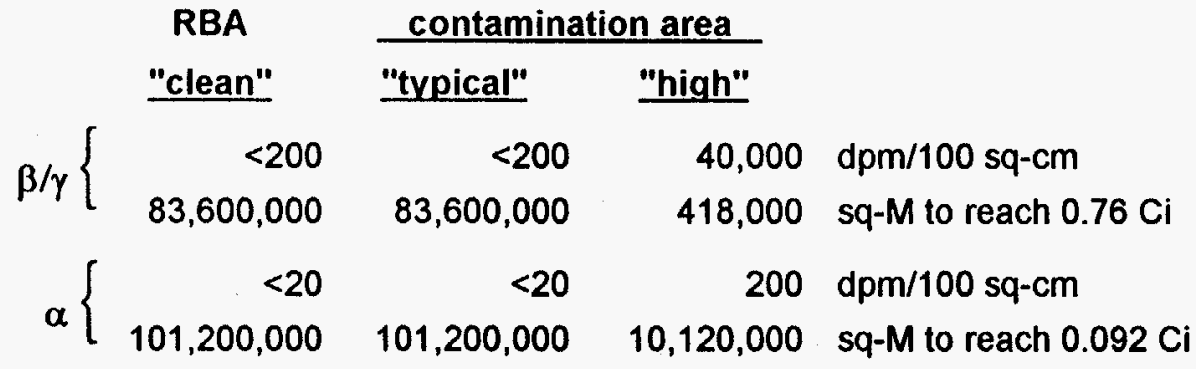

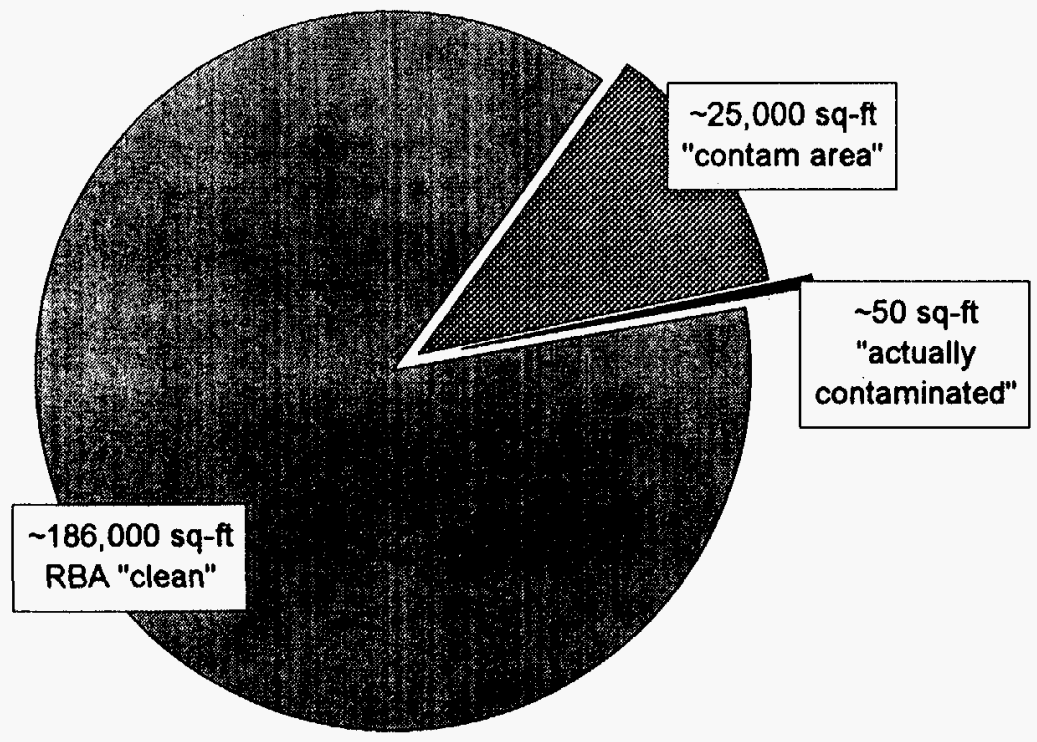

(18) B-25 boxes -- all read $<1 \mathrm{mR} / \mathrm{hr}$ using R02 meter

(172) 21" cardboard boxes had various rates:

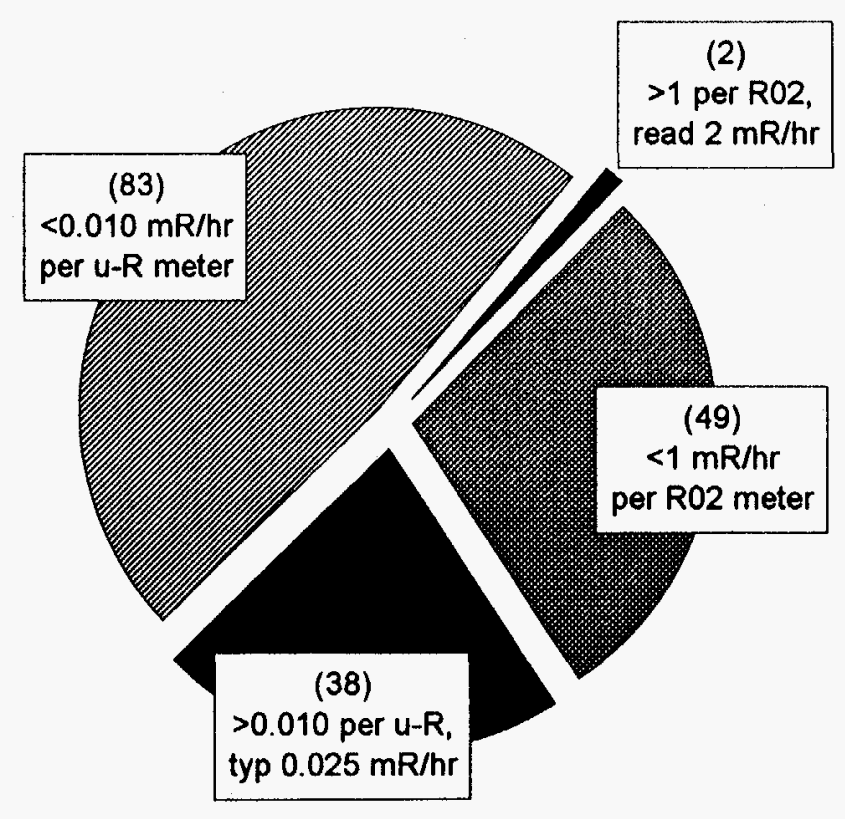




\begin{tabular}{|c|c|c|c|c|c|c|c|c|c|c|}
\hline & $\begin{array}{c}\text { WAC } 3.10 \\
\text { (CU/package) } \\
\text { - or - } \\
\text { TCLP } \\
\text { leachate } \\
\text { (mg /LL) }\end{array}$ & $\begin{array}{c}\text { ETF } \\
\text { concentrate } \\
\text { samples } \\
\text { (Ci/gal) } \\
- \text { or - } \\
(\mathrm{mg} / 4)\end{array}$ & $\begin{array}{l}\text { other } \\
\text { radio- } \\
\text { nuclides, } \\
\text { scaled to } \\
\text { Cs-137 } \\
\text { - or - } \\
\text { gross- } \alpha \\
\text { (Ci / gal) }\end{array}$ & $\begin{array}{c}\text { U-235 } \\
\text { Fissile } \\
\text { Gram } \\
\text { Equivalent } \\
\text { (gm / gal) }\end{array}$ & $\begin{array}{c}\text { contam. } \\
\text { present } \\
\text { in } 100 \text { gal } \\
\text { of concen. } \\
\text { (Ci) } \\
- \text { or }- \\
\text { (mg) } \\
\end{array}$ & \begin{tabular}{|} 
for 100 gal of \\
concentrate \\
in a $1000 \mathrm{lb}$ \\
package: \\
fraction of \\
WAC 3.10 \\
- or - \\
TCLP \\
\end{tabular} & $\begin{array}{c}\text { concentrate } \\
\text { volume for } \\
\text { a } 1000 \text { Ib } \\
\text { package to be } \\
100 \% \text { of WAC } \\
- \text { or - } \\
100 \% \text { of TCLP } \\
\text { (gal) } \\
\end{array}$ & $\begin{array}{l}\text { for } 2 \text { gal of } \\
\text { concentrate } \\
\text { in a } 25 \text { lb } \\
\text { package: } \\
\text { fraction of } \\
\text { WAC } 3.04 \\
- \text { or }- \\
\text { TCLP } \\
\end{array}$ & $\begin{array}{c}\text { concentrate } \\
\text { volume for } \\
\text { a } 25 \text { ib } \\
\text { package to be } \\
100 \% \text { of WAC } \\
- \text { or - } \\
100 \% \text { of TCLP } \\
\text { (gal) }\end{array}$ & manifest as \\
\hline $\begin{array}{l}\text { gross }-\beta / \gamma= \\
\text { other- } \beta / \gamma=\end{array}$ & $2 . \bar{E}+\infty$ & $\begin{array}{l}1.10 E-05 \\
2.67 E-06\end{array}$ & $\cdots$ & - & $2 . \overline{67 E}-04$ & $0 . \overline{000116}$ & $\overline{859,820}$ & 0.000028 & $-71,652$ & $\overline{<M R Q}$ \\
\hline $\begin{array}{l}\text { gross- } \alpha \\
\text { other- } \alpha\end{array}$ & $3 . \overline{70 E-03}$ & $\begin{array}{l}1.64 E-07 \\
1.64 E-07\end{array}$ & - & $\overrightarrow{-}$ & $1 . \overline{64 E-05}$ & 0.004437 & $-_{22,536}$ & 0.001065 & ${ }^{-} 1,878$ & $\overline{<}$ MRQ \\
\hline $\begin{array}{l}\mathrm{H}-3 \\
\mathrm{C}-14 \\
\mathrm{Ni}-59 \\
\mathrm{CO}-60\end{array}$ & $\begin{array}{l}1.00 E+01 \\
3.30 E-03 \\
6.30 E-02 \\
2.30 E+01\end{array}$ & $\begin{array}{c}\text { 6.30E-05 } \\
\overline{-} \\
8.14 \mathrm{E}-08\end{array}$ & $\begin{array}{c}2 . \overline{19 E-13} \\
3.48 E-12 \\
-\end{array}$ & $\bar{m}$ & $\begin{array}{l}6.30 E-03 \\
2.19 E-11 \\
3.48 E-10 \\
8.14 E-06\end{array}$ & $\begin{array}{l}0.000630 \\
0.000000 \\
0.000000 \\
0.000000\end{array}$ & $\begin{array}{r}158,841 \\
15,069,095,048 \\
18,119,250,694 \\
282,587,309\end{array}$ & $\begin{array}{l}0.000151 \\
0.000000 \\
0.000000 \\
0.000000\end{array}$ & $\begin{array}{r}13,237 \\
1,255,757,921 \\
1,509,937,558 \\
23,548,942\end{array}$ & $\begin{array}{l}<\text { MRQ } \\
<\text { MRQ } \\
<\text { MRQ } \\
<\text { MRQ }\end{array}$ \\
\hline $\begin{array}{l}\text { Se-79 } \\
\text { Sr-90 } \\
\text { Tc-99 }\end{array}$ & $\begin{array}{l}5.20 E-04 \\
1.10 E+\infty 0 \\
1.70 E-04\end{array}$ & $\overline{-}$ & $\begin{array}{l}1.46 E-11 \\
1.83 E-06 \\
1.08 E-09\end{array}$ & $\bar{m}$ & $\begin{array}{l}1.46 E-09 \\
1.83 E-04 \\
1.08 E-07\end{array}$ & $\begin{array}{l}0.000003 \\
0.000166 \\
0.000635\end{array}$ & $\begin{array}{r}35,713,447 \\
601,925 \\
157,436\end{array}$ & $\begin{array}{l}0.000001 \\
0.000040 \\
0.000152\end{array}$ & $\begin{array}{r}2,976,121 \\
50,160 \\
13,120\end{array}$ & $\begin{array}{l}<\text { MRQ } \\
<\text { MRQ } \\
<\text { MRQ }\end{array}$ \\
\hline $\begin{array}{l}\text { Sn-126 } \\
\text { l-129 } \\
\text { Cs-137 }\end{array}$ & $\begin{array}{l}2.90 E-04 \\
8.30 E-08 \\
7.60 E-01\end{array}$ & $\overline{\overline{-}} \overline{-}$ & $\begin{array}{l}1.32 \mathrm{E}-12 \\
1.48 \mathrm{E}-12 \\
8.30 \mathrm{E}-06\end{array}$ & $\overline{-}$ & $\begin{array}{l}1.32 E-10 \\
1.48 E-10 \\
8.30 E-04\end{array}$ & $\begin{array}{l}0.000000 \\
0.001786 \\
0.001092\end{array}$ & $\begin{array}{r}220,090,932 . \\
55,997 \\
91,585\end{array}$ & $\begin{array}{l}0.000000 \\
0.000429 \\
0.000262\end{array}$ & $\begin{array}{r}18,340,911 . \\
4,666 . \\
7,632\end{array}$ & $\begin{array}{l}<\text { MRQ } \\
<\text { MRQ } \\
\text { per dose-to-curie }\end{array}$ \\
\hline $\begin{array}{l}U-233 \\
U-234 \\
U-235 \\
U-236 \\
U-238\end{array}$ & $\begin{array}{l}2.20 E-05 \\
7.50 E-03 \\
1.10 E-04 \\
1.40 E-03 \\
2.30 E-03\end{array}$ & $\bar{z}$ & $\begin{array}{l}4.72 \mathrm{E}-12 \\
2.80 \mathrm{E}-10 \\
3.15 \mathrm{E}-12 \\
7.69 \mathrm{E}-11 \\
7.67 \mathrm{E}-11\end{array}$ & $\begin{array}{c}6.83 E-10 \\
\overline{-} \\
1.46 E-06 \\
- \\
-\end{array}$ & $\begin{array}{l}4.72 E-10 \\
2.80 E-08 \\
3.15 E-10 \\
7.69 E-09 \\
7.67 E-09\end{array}$ & $\begin{array}{l}0.000021 \\
0.000004 \\
0.000003 \\
0.000005 \\
0.000003\end{array}$ & $\begin{array}{r}4,656,570 . \\
26,833,444 . \\
34,918,274 . \\
18,204,454 . \\
29,992,804 .\end{array}$ & $\begin{array}{l}0.000005 \\
0.000001 \\
0.000001 \\
0.000001 \\
0.000001\end{array}$ & $\begin{array}{r}388,048 . \\
2,236,120 . \\
2,909,856 . \\
1,517,038 . \\
2,499,400 .\end{array}$ & $\begin{array}{l}<\text { MRQ } \\
<\text { MRQ } \\
<\text { MRQ } \\
<\text { MRQ } \\
<\text { MRQ }\end{array}$ \\
\hline $\begin{array}{l}\text { Pu-238 } \\
\text { Pu-239 } \\
\text { Pu-240 } \\
\text { Pu-241 } \\
\text { Pu-242 }\end{array}$ & $\begin{array}{l}9.10 E-02 \\
9.10 E-02 \\
9.10 E-02 \\
1.10 E+00 \\
9.10 E-02\end{array}$ & $\bar{z}$ & $\begin{array}{l}1.56 E-07 \\
1.51 E-08 \\
3.38 E-09 \\
1.47 E-07 \\
1.56 E-11\end{array}$ & $\begin{array}{c}\overline{1.06 \mathrm{E}-07} \\
\overline{-} \\
1.34 \mathrm{E}-04 \\
-\end{array}$ & $\begin{array}{l}1.56 E-05 \\
1.51 E-06 \\
3.38 E-07 \\
1.47 E-05 \\
1.56 E-09\end{array}$ & $\begin{array}{l}0.000171 \\
0.000017 \\
0.000004 \\
0.000013 \\
0.000000\end{array}$ & $\begin{array}{r}583,591 . \\
6,026,856 . \\
26,914,776 . \\
7,499,368 \\
5,819,310,777\end{array}$ & $\begin{array}{l}0.000041 \\
0.000004 \\
0.000001 \\
0.000003 \\
0.000000\end{array}$ & $\begin{array}{r}48,633 . \\
502,238 \\
2,242,898 \\
624,947 \\
484,942,565\end{array}$ & $\begin{array}{l}<\text { MRO } \\
<\text { MRQ } \\
<\text { MRQ } \\
<\text { MRO } \\
<\text { MRO }\end{array}$ \\
\hline Np-237 & 2.20E-05 & $\ldots$ & $2.68 E-11$ & - & $2.68 E-09$ & 0.000122 & 820,145 . & 0.000029 & 68,345 . & $<$ MRQ \\
\hline Am-241 & $9.10 E-02$ & -- & $7.79 E-09$ & - & $7.79 E-07$ & 0.000000 & $11,680,314$ & 0.000002 & $973,360$. & < < MRQ \\
\hline totalfGE $(\mathrm{gm})$ & $5.00 E+01$ & - & - & $1.36 E-04$ & $1.36 E-02$ & 0.000272 & 367,575 . & 0.000136 & 14,703 . & $<$ MRQ \\
\hline $\begin{array}{l}\text { arsenic } \\
\text { barium } \\
\text { cadmium } \\
\text { chromium }\end{array}$ & $\begin{array}{c}5 . \\
100 . \\
1 . \\
5 .\end{array}$ & $\begin{array}{l}10.00 \\
10.01 \\
10.00 \\
11.62\end{array}$ & $\overline{-}$ & $\overline{-}$ & $\begin{array}{l}3,785 \\
3,788 \\
3,785 \\
4,397\end{array}$ & $\begin{array}{l}0.083444 \\
0.004176 \\
0.417218 \\
0.096944\end{array}$ & $\begin{array}{r}1,198 \\
23,949 . \\
240 \\
1,032\end{array}$ & $\begin{array}{l}0.066755 \\
0.003340 \\
0.333774 \\
0.077555\end{array}$ & $\begin{array}{r}30.0 \\
598.7 \\
6.0 \\
25.8\end{array}$ & $\begin{array}{l}\text { non-hazardous } \\
\text { non-hazardous } \\
\text { non-hazardous } \\
\text { non-hazardous }\end{array}$ \\
\hline $\begin{array}{l}\text { lead } \\
\text { mercury } \\
\text { selenium } \\
\text { silver }\end{array}$ & $\begin{array}{c}5 . \\
0.2 \\
1 . \\
5 .\end{array}$ & $\begin{array}{c}10.16 \\
2.72 \\
4.03 \\
10.17\end{array}$ & $\bar{m}$ & $\bar{m}$ & $\begin{array}{l}3,845 \\
1,028 \\
1,525 \\
3,849\end{array}$ & $\begin{array}{l}0.084757 \\
0.566647 \\
0.168091 \\
0.084858\end{array}$ & $\begin{array}{r}1,180 \\
176 \\
595 \\
1,178\end{array}$ & $\begin{array}{l}0.067805 \\
0.453317 \\
0.134473 \\
0.067886\end{array}$ & $\begin{array}{r}29.5 \\
4.4 \\
14.9 \\
29.5\end{array}$ & $\begin{array}{l}\text { non-hazardous } \\
\text { non-hazardous } \\
\text { non-hazardous } \\
\text { non-hazardous }\end{array}$ \\
\hline
\end{tabular}

\section{Notes (see additional discussion in the report text):}

- ETF's influent wastewater concentrations are $\sim 80 x$ lower than the concentrate analyses. Thus these amounts, fractions, and volumes correctly apply to that portion of ETF waste that is contaminated with concentrate, but they are $\sim 80 x$ conservative for the large portion of ETFs solid waste which is contaminated with the more dilute liquids.

* ETFs average "gross $-\beta / \gamma$ " is adjusted to a conservative "other- $\beta / \gamma$ " by subtracting the average Cs- 137 (since essentially all of ETFs "gross- $\beta / \gamma$ " is Cs137, as shown in Chart 6).

m" ETF's average "gross- $\alpha$ " is conservatively compared to the WAC values for "other- $\alpha$ ". In reality, some large fraction of the "gross- $\alpha$ " must actually be the U/Pu/Np/Am radionuclides (which are scaled from the "gross- $\alpha$ "), but there is no basis to determine the proper fraction. If the "grose- $\alpha$ " were adjusted to eliminate this "double-counting", then the "fraction of other- $\alpha$ PAC" would be reduced by some large factor (and the "volume for 100\% of other-a PAC" would be increased). However, even this conservative bound satisfactorily demonstrates that ETF\& waste will meet the PAC.

ETF's metals analysis has a $10 \mathrm{mg} / \mathrm{L}$ detection limit (except $2 \mathrm{mg} / \mathrm{L}$ for $\mathrm{Hg}$ and $4 \mathrm{mg} / \mathrm{L}$ for Se) - this mostly accounts for the values shown. A more sensitive analysis (that showed actual concentrations) would reduce the apparent "fraction of TCLP", but even this conservative bound satisfactorily demonstrates that ETFs waste will be non-hazardous. 
Actinides - in Separations \& Sent to Waste $\left(^{\circ}=\right.$ values from rev-0 of DPSTD-80-39)

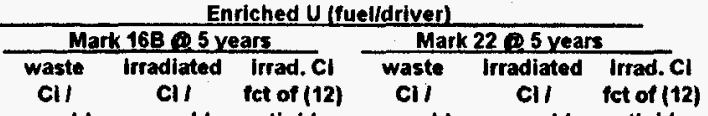

assembly assembly actinides assembly assembly tet of (12)

U-233

$u-234$

$U-235$

U-236

U-238

Pu-238

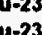

Pu-240

Pu-241

Pu-242

Np-237

0.

0.

0.

0 .

$\begin{array}{cc}0 . & 0 . \\ 1.510 E-03\end{array}$

$\begin{array}{llllll}6.110 E-06 & 4.073 E-03 & 1.573 E-05 & 6.123 E-06 & 3.212 E-01 & 1.510 E-03 \\ 1.082 E-03 & 1.919 E-05\end{array}$ 1.819E-04 1.213E-01 4.684E-04 1.119E-04 7.461E-02 3.507E-04 B.T

1.213E+02 1.213E+02 4.684E-01 9.605E+01 9.605E+01 4.515E-01 $\begin{array}{llllll}9.827 E-01 & 9.827 E-01 & 3.795 E-03 & 7.949 E-01 & 7.949 E-01 & 3.737 E-03\end{array}$ $\begin{array}{llllll}7.238 E-01 & 7.238 E-01 & 2.795 E-03 & 5.272 E-01 & 5.272 E-01 & 2.478 E-03\end{array}$ $\begin{array}{llllll}1.341 E+02 & 1.341 E+02 & 5.179 E-01 & 1.139 E+02 & 1.139 E+02 & 5.354 E-01\end{array}$ $\begin{array}{llllll}2.571 E+02 & 2.571 E+02 & 9.930 E-01 & 2.113 E+02 & 2.113 E+02 & 9.931 E-01\end{array}$

267E-03 $3.906 E-02 \quad 1.508 E-04 \quad 1.023 E-03 \quad 2.922 E-02 \quad 1.374 E-04$

$\begin{array}{lllllll}\text { Am-241 } & 1.214 E+\infty 0 & 1.214 E+00 & 4.689 E-03 & 1.033 E+00 & 1.033 E+00 & 4.856 E-03\end{array}$

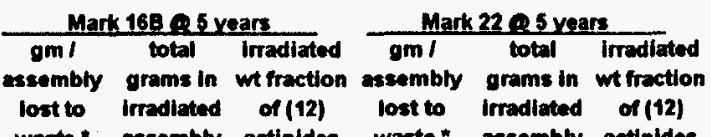

warte" asemply actinides warte"

$\begin{array}{cccccc}0 & 0 & 0 & 0 & 0 & 0\end{array}$ $\begin{array}{llllll}1.058 \mathrm{E}-01 & 7.056 \mathrm{E}+01 & 1.517 \mathrm{E}-02 & 7.712 \mathrm{E}-02 & 5.141 \mathrm{E}+01 & 1.423 \mathrm{E}-02 \\ 2827 \mathrm{E}+0 & 1.885 \mathrm{E}+03 & 4.053 \mathrm{E}-01 & 2.833 \mathrm{E}+00 & 1.889 \mathrm{E}+03 & 5.228 \mathrm{E}-01\end{array}$ $\begin{array}{llllll}2.827 \mathrm{E}+00 & 1.885 \mathrm{E}+03 & 4.053 \mathrm{E}-01 & 2.833 \mathrm{E}+00 & 1.889 \mathrm{E}+03 & 5.228 \mathrm{E}-01 \\ 2813 \mathrm{E}+0 & 1.875 \mathrm{E}+03 & 4.032 \mathrm{E}-01 & 1.730 \mathrm{E}+00 & 1.153 \mathrm{E}+03 & 3.192 \mathrm{E}-01\end{array}$ $\begin{array}{llllll}2.813 E+\infty 0 & 1.875 E+03 & 4.032 E-01 & 1.730 E+\infty & 1.153 E+03 & 3.192 E-01 \\ 1.104 E+\infty 0 & 7.362 E+02 & 1.583 E-01 & 6.835 E-01 & 4.556 E+02 & 1.261 E-01\end{array}$ $\begin{array}{lllllll}1.104 E+00 & 7.362 E+02 & 1.583 E-01 & 6.835 E-01 & 4.556 E+02 & 1.261 E-01\end{array}$ $\begin{array}{llllll}1.581 E+01 & 1.581 E+01 & 3.400 E-03 & 1.279 E+01 & 1.279 E+01 & 3.540 E-03\end{array}$ $\begin{array}{llllll}3.176 E+\infty & 3.176 E+\infty & 6.828 E-04 & 2.313 E+00 & 2.313 E+00 & 6.402 E-04\end{array}$

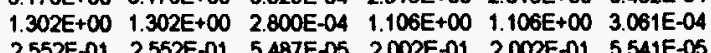
$\begin{array}{llllll}1.939 E+\infty & 5.541 E+01 & 1.192 E-02 & 1.451 E+\infty & 4.146 E+01 & 1.147 E-02\end{array}$

$\begin{array}{lllllll}M p-237 & 1.939 E+\infty & 5.541 E+01 & 1.192 E-02 & 1.451 E+\infty & 4.146 E+01 & 1.147 E-02\end{array}$

Am-281

$x$ lost to

waste

$u-233$

U-234

$U-235$
$U-236$

$U-236$
$U-238$

Pu-238 $\quad 100.00 \%$

$\begin{array}{ll}\text { Pu-239 } & 100.00 \% \\ P u-240 & 100.00 \%\end{array}$

Pu-241 $100.00 \%$

Pu-242 $100.00 \%$

Np-237 $\quad 3.50 \%$

Am-241 $100.00 \%$

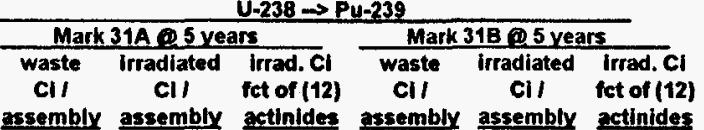

$\begin{array}{cccccc}0 . & 0 . & 0 & 0 & 0 . & 0 . \\ 8.900 E-20 & 4.450 E-16 & 1.658 E-18 & 6.064 E-20 & 3.032 E-16 & 1.766 E-18\end{array}$

$\begin{array}{llllll}8.900 E-20 & 4.450 E-16 & 1.658 E-18 & 6.064 E-20 & 3.032 E-16 & 1.766 E-18 \\ 2594 E-07 & 1.297 E-03 & 4.833 E-06 & 1.717 E-07 & 8.586 E-04 & 5.001 E-06\end{array}$ $\begin{array}{lllllll}2.594 E-07 & 1.297 E-03 & 4.833 E-06 & 1.717 E-07 & 8.586 E-04 & 5.001 E-06 \\ 2.418 E-07 & 1.209 E-03 & 4.506 E-06 & 1.781 E-07 & 8.906 E-04 & 5.187 E-06\end{array}$ $2.362 E-05 \quad 1.181 E-01 \quad 4.402 E-04 \quad 1.604 E-05 \quad 8.020 E-02 \quad 4.671 E-04$ 2.412E-05 1.206E-01 4.45SE-04 1.639E-05 8.195E-02 4.773E-04 $2.160 E-03 \quad 9.817 E-01 \quad 3.659 E-03 \quad 1.144 E-03 \quad 5.200 E-01 \quad 3.029 E-03$ $\begin{array}{llllll}4.949 E-02 & 2.250 E+01 & 8.384 E-02 & 3.474 E-02 & 1.579 E+01 & 9.497 E-02\end{array}$ $\begin{array}{lllllll}1.045 E-02 & 4.750 E+00 & 1.770 E-02 & 7.779 E-03 & 3.536 E+00 & 2.059 E-02\end{array}$ $\begin{array}{lllllll}5.274 E-01 & 2.397 E+02 & 8.934 E-01 & 3.336 E-01 & 1.516 E+02 & 8.830 E-01\end{array}$ 5.895E-01 2.679E+02 9.986E-01 3.772E-01 $1.715 E+02 \quad 9.986 E-01$ 8.544E-06 1.424E-04 5.307E-07 $5.263 \mathrm{E}-06 \quad 8.772 \mathrm{E}-05 \quad 5.109 \mathrm{E}-07$ 2.518E-01 2.518E-01 9.385E-04 1.567E-01 1.567E-01 9.124E-04 $\frac{\text { Mark 31A Q 5 vears }}{\mathrm{gm} / \text { total irradiated }} \frac{\text { Mark } 318 \text { Q } 5 \text { years }}{\mathrm{gm} / \text { total irradiated }}$ assembly grams in wifraction assembly grams in wt fraction lost to Irrediated of (12) lost to Irrediatod of (12) waste " assembly ectinldes warte" assembly zetinides $\begin{array}{cccccc}0 & 0 & 0 & 0 & 0 & 0 \\ 1.424 \mathrm{E}-17 & 7.122 \mathrm{E}-14 & 2.022 \mathrm{E}-19 & 9.705 \mathrm{E}-18 & 4.853 \mathrm{E}-14 & 2.028 \mathrm{E}-19\end{array}$ $\begin{array}{llllll}1.424 E-17 & 7.122 E-14 & 2.022 E-19 & 9.705 E-18 & 4.853 E-14 & 2.028 E-19 \\ 1.200 E-01 & 6.001 E+02 & 1.703 E-03 & 7.947 E-02 & 3.973 E+02 & 1.651 E-03\end{array}$

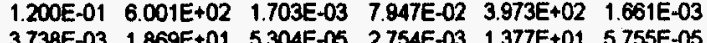
$\begin{array}{llllll}3.738 E-03 & 1.869 E+01 & 5.304 E-06 & 2.754 E-03 & 1.372+01 & 5.755 E-05 \\ 7.026 E+01 & 3.513 E+05 & 9.971 E-01 & 4.771 E+01 & 2.386 E+05 & 9.971 E-01\end{array}$ 1.262E-04 5.734E-02 1.628E-07 6683E-05 $33038 E-02 \quad 1$ 270E-07 $\begin{array}{llllll}7.962 E-01 & 3.619 E+02 & 1.027 E-03 & 5.589 E-01 & 2.540 E+02 & 1.062 E-03\end{array}$ 4.585E-02 2.084E+01 $5.916 E-05 \quad 3.414 E-02 \quad 1.552 E+01 \quad 6.486 E-05$

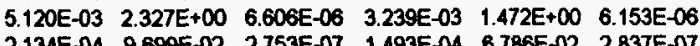

$\begin{array}{lllllll}1.212 E-02 & 2.020 E-01 & 5.734 E-07 & 7.466 E-03 & 1.244 E-01 & 5.202 E-07\end{array}$ $\begin{array}{llllll}7.337 E-02 & 7.337 E-02 & 2.082 E-07 & 4.564 E-02 & 4.564 E-02 & 1.908 E-07\end{array}$

\begin{tabular}{l} 
W lost to \\
waste: \\
\hline $0.02 \%$ \\
$0.02 \%$ \\
$0.02 \%$ \\
$0.02 \%$ \\
$0.02 \%$ \\
$0.22 \%$ \\
$0.22 \%$ \\
$0.22 \%$ \\
$0.22 \%$ \\
$0.22 \%$ \\
$6.00 \%$ \\
$100.00 \%$
\end{tabular}

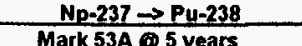

waste irradiated Irrad. CI CII Cll fet of (12) axsembly assembly actinide: $\begin{array}{ccc}0 . & 0 . & 0 . \\ 5.494 E-17 & 5.494 E-17 & 1.442 E-20\end{array}$ $\begin{array}{lll}5.494 E-17 & 5.494 E-17 & 1.442 E-20 \\ 1.307 E-20 & 1.307 E-20 & 3.431 E-24\end{array}$ $\begin{array}{lll}1.307 E-20 & 1.307 E-20 & 3.431 E-24 \\ 7.492 E-19 & 7.492 E-19 & 1.967 E-22\end{array}$ $\begin{array}{lll}7.492 E-19 & 7.492 E-19 & 1.967 E-22 \\ 3.605 E-21 & 3.605 E-21 & 9.464 E-25\end{array}$ $\begin{array}{lll}3.605 E-21 & 3.605 E-21 & 9.464 E-25 \\ 5.570 E-17 & 5.570 E-17 & 1.462 E-20\end{array}$

$6.150 E+00 \quad 3.618 E+03 \quad 9.498 E-01$ 4.497E-03 2.645E +00 6.945E-04 3.136E-03 1.845E+00 4.843E-04 3.163E-01 $1.861 E+02 \quad 4.884 E-02$ $\begin{array}{lll}2.228 E-06 & 1.311 E-03 & 3.440 E-07 \\ 6.474 E+00 & 3.808 E+03 & 9.998 E-01\end{array}$ 6.224E-04 6.224E-01 1.634E-04 $1.814 E-01 \quad 1.814 E-01 \quad 4.762 E-05$

\begin{tabular}{|c|c|c|c|}
\hline \begin{tabular}{l}
\multicolumn{1}{c}{ Marks } \\
asmembly \\
assemt to \\
loste \\
waste
\end{tabular} & $\begin{array}{c}\text { 3A cos yea } \\
\text { total } \\
\text { grams in } \\
\text { Irradiated } \\
\text { assembly }\end{array}$ & $\begin{array}{l}\text { Irradiated } \\
\text { wt fraction } \\
\text { of (12) } \\
\text { actinides }\end{array}$ & \\
\hline $\begin{array}{c}0 \\
8.792 E-15 \\
6.049 E-15 \\
1.158 E-14 \\
1.072 E-14\end{array}$ & $\begin{array}{c}0 \\
8.792 E-15 \\
6.049 E-15 \\
1.158 E-14 \\
1.072 E-14\end{array}$ & $\begin{array}{c}0 \\
7.665 \mathrm{E}-18 \\
5.273 \mathrm{E}-18 \\
1.010 \mathrm{E}-17 \\
9.348 \mathrm{E}-18\end{array}$ & \\
\hline $\begin{array}{l}3.593 E-01 \\
7.235 E-02 \\
1.376 E-02 \\
3.071 E-03 \\
5.835 E-04\end{array}$ & $\begin{array}{l}2.113 E+02 \\
4.256 E+01 \\
8.096 E+00 \\
1.806 E+00 \\
3.432 E-01\end{array}$ & $\begin{array}{l}1.842 \mathrm{E}-01 \\
3.710 \mathrm{E}-02 \\
7.057 \mathrm{E}-03 \\
1.575 \mathrm{E}-03 \\
2.992 \mathrm{E}-04\end{array}$ & \\
\hline $8.829 E-01$ & $8.829 E+02$ & 7.697E-01 & \\
\hline $\begin{array}{l}5.285 E-02 \\
\times \text { lost to } \\
\text { waste " }\end{array}$ & 5.285E-02 & 4.607E-05 & $\begin{array}{l}\text { for each of the (12) actinides: } \\
\text { the largest Ci fraction in } \\
\text { any of the (6) "rexiper" }\end{array}$ \\
\hline $\begin{array}{l}100.00 \% \\
100.00 \% \\
100.00 \% \\
100.00 \% \\
100.00 \%\end{array}$ & & & $\begin{array}{l}2.878 E-05 \\
1.702 E-03 \\
1.919 E-05 \\
4.684 E-04 \\
4.674 E-04\end{array}$ \\
\hline $\begin{array}{l}0.17 \% \\
0.17 \% \\
0.17 \% \\
0.17 \% \\
0.17 \%\end{array}$ & & & $\begin{array}{l}\text { 9.A98E-01 } \\
9.197 E-02 \\
2.059 E-02 \\
8.934 E-01 \\
9.525 E-05\end{array}$ \\
\hline $0.10 \%$ & & & $1.634 E-04$ \\
\hline $100.00 \%$ & & & 4.745E-02 \\
\hline
\end{tabular}

tank farm supernate

ci fraction tank farm ci rraction (ea) U, Pu, Inventory of (12) No\&Am Cl metinides

$0.54100 \quad 1.061 E+02 \quad 2.878 E-05$ $0.15400 \quad 3.021 E+01 \quad 8.191 E-06$ $0.00900 \quad 1.765 \mathrm{E}+00 \quad 4.787 \mathrm{E}-07$ $\begin{array}{lll}0.02500 & 4.904 E+\infty & 1.330 E-06 \\ 0.27100 & 5.316 E+01 & 1.441 E-05\end{array}$ $\begin{array}{lll}1 . & 1.962 \mathrm{E}+02 & 5.319 \mathrm{E}-05\end{array}$

$0.55680 \quad 1.956 E+06 \quad 5.303 E-01$ $0.01040 \quad 3.653 \mathrm{E}+04 \quad 9.906 \mathrm{E}-03$ $0.00470 \quad 1.651 \mathrm{E}+04 \quad 4.477 \mathrm{E}-03$ $0.42800 \quad 1.503 E+06 \quad 4.077 E-01$

$\begin{array}{lll}.00010 & 3.513 E+02 & 9.525 E-05 \\ 1 . & 3.513 E+06 & 9.525 E-01\end{array}$

1. 7.000E+01 1.898E-05 $1.1750 E+05 \quad 4745 E-02$

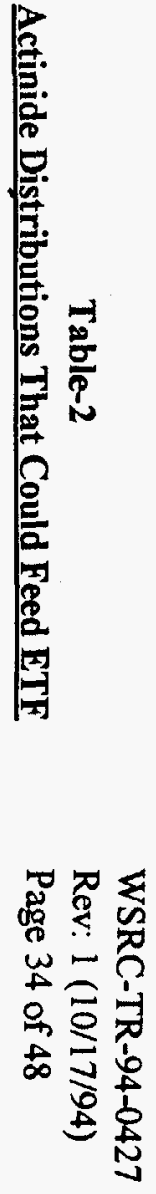


sample data analysis Arsenic Barium Cadmium Chromium Lead Mercury Selenium Silver data Co-60 Cs-137 Am-241 others

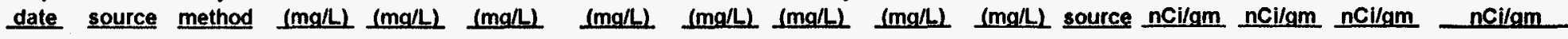

regulatory limits

waste stream ETF-001(a):

treatment plant smears

waste stream ETF-001/b):

F retention basin sediment

$H$ retention bas in sediment

$H$ retention basinsediment

5. 100

$03 / 93$

B1

dissol

$<0.20<0.02$

$<0.10$

$<0.05<0.50<0.0114$

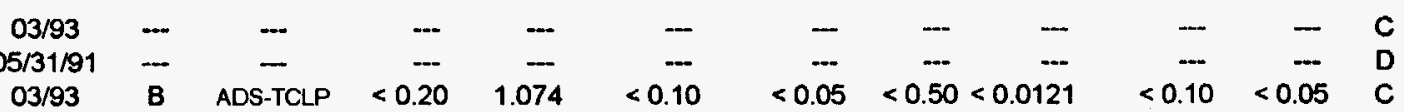

$<0.05<0.50<0.0121$

$<0.10<0.05 \quad \mathrm{C}$

$\begin{array}{lrrr}\text { ND } & \text { ND } & \text { ND } & \text { ND } \\ \text { ND } & 1.11 & \text { ND } & 0.016 \quad \text { Cs-134 } \\ \text { ND } & 1.8 & \text { ND } & \text { ND }\end{array}$

waste stream ETF-001(c):

\section{HPK-25 sample \\ HPK-25 column \#2}

$03 / 93 \quad B \quad$ ADS-TCLP $<0.20 \quad 0.673<0.10$

$<0.05<0.50<0.0121<0.10<0.05-$

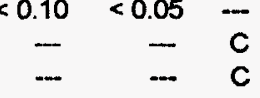

ND $\quad 2.1$

$-\overline{N D}-$

HPK-25 column \#3

waste stream ETF-002:

GT-73 sample

GT-73 sample

GT-73 column \#1

GT.73 column \#2

GT-73 column \#3

waste stream ETF-003:

carbon sample

carbon sample

carbon bed $\$ 2$

carbon bed \#4

carbon bed $\$ 5$

$\begin{array}{lllllllll}03 / 93 & - & - & - & - & - & - & - & - \\ 03 / 93 & - & - & - & - & - & - & - & -\end{array}$

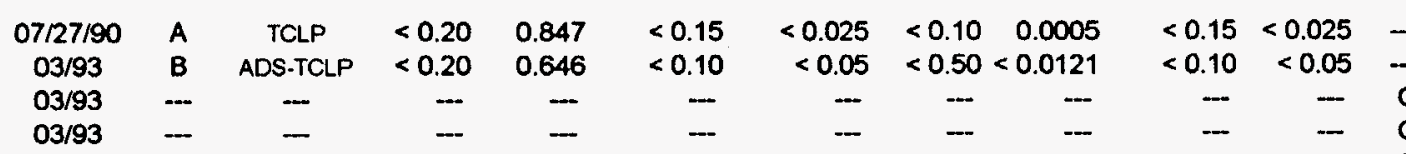

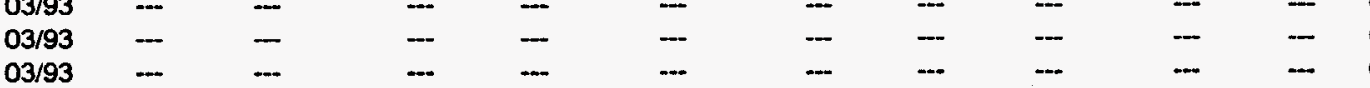

$05 / 22 / 90 \quad A \quad$ TCLP $\quad<0.20 \quad 0.658<0.15$

$<0.025<0.10 \quad 0.002<0.15<0.025-$

$03 / 93 \quad$ B $\quad$ ADS-TCLP $<0.20 \quad 5.235$

$<0.10$

$<0.05<0.50<0.0121$

$03 / 93$

$03 / 93$

$-$

$\overline{-} \quad \overline{-}$

$-$

$-$

-.

$\begin{array}{ccc}0.116 & <0.05 & - \\ -- & - & c\end{array}$

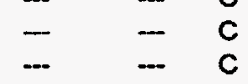

max nCi/gm:

Ci PAC:

Ib waste @ PAC:

\begin{tabular}{|c|c|c|}
\hline ND & 0.53 & ND \\
\hline- & - & -..- \\
\hline ... & ... & $\cdots$ \\
\hline 0.129 & 2.79 & 0.96 \\
\hline 0.156 & 3.39 & 0.45 \\
\hline 0.168 & 1.23 & 0.54 \\
\hline- & - & \\
\hline$\cdots$ & - & \\
\hline ND & 0.22 & ND \\
\hline ND & 0.34 & ND \\
\hline ND & 0.36 & 0.53 \\
\hline 0.168 & 3.39 & \\
\hline 23. & 0.76 & \\
\hline
\end{tabular}

notes \& data sources:

ND $=$ Not Detected

A. Report from MetaTrace Inc; coverletter dated 9/17/90, analysis by official TCLP leaching methodology.

B. Analytical slips from L Lovo analye by the ADS Lab's screening variation of TCLP (results are comparable to the "official" TCLP method).

B1. Analytical slips from L.L.Tovo, analysis by diseotving the samples in "aqua regia" acid. This method is used as screening tool.

If the total metal content is too high, then leachable metals would be measured, by the (less aggressive) TCLP method.

C. Ref 11 .

D. Email of analytical results from J.D.Leyba to J.R.Cantrell, 06/19/91. 


\section{Table-4}

Detectable Quantities in Recent Analysis of ETF Adsorbant Wastes (these apply to samples in Table-2 that are noted to have "data source C")

\begin{tabular}{|c|c|c|c|c|}
\hline & $\begin{array}{c}\text { LAWV PAC } \\
\text { (WAC 3.10, } \\
05 / 21 / 94) \\
\mathrm{Ci} \\
\end{array}$ & $\begin{array}{c}\text { analytical } \\
\text { detection } \\
\text { limit given } \\
\text { in ref } 11 \\
\text { pCi/gm }\end{array}$ & $\begin{array}{l}\text { - weight } \\
\text { of waste } \\
\text { required for } \\
\text { package } \\
\text { to reach the } \\
\text { LAWV PAC } \\
\text { @ detect limit } \\
\text { lbs } \\
\end{array}$ & $\begin{array}{l}\text { * weight } \\
\text { of waste } \\
\text { required fo } \\
\text { package } \\
\text { to reach the } \\
253-H \text { PAC } \\
\text { @ detect lim } \\
\text { lbs } \\
\end{array}$ \\
\hline Other Beta/Gamma & $2.3 E+00$ & 660 & $7,682,647$ & 640,221 \\
\hline Other Alpha & 3.7E-03 & 330 & 24,718 & 2,060 \\
\hline $\mathrm{H}-3$ & $1.0 \mathrm{E}+01$ & 85 & $259,363,004$ & $21,613,584$ \\
\hline$C-14$ & 3.3E-03 & 70 & 103,930 & 8,661 \\
\hline Co-60 & 2.3E+01 & 70 & $724,363,820$ & $60,363,652$ \\
\hline $\mathrm{Ni}-59$ & $6.3 E-02$ & 260 & 534,188 & 44,516 \\
\hline Se-79 & $5.2 E-04$ & 70 & 16,377 & 1,365 \\
\hline Sr-90 & 1.1E+00 & 70 & $34,643,487$ & $2,886,957$ \\
\hline Tc-99 & $1.7 \mathrm{E}-04$ & 70 & 5,354 & 446 \\
\hline Sn-126 & $2.9 E-04$ & 660 & 968.7 & 80.7 \\
\hline I-129 & 8.3E-08 & 70 & 2.61 & 0.22 \\
\hline Cs-137 & 7.6E-01 & 70 & $23,935,500$ & $1,994,625$ \\
\hline U-233 & $2.2 \mathrm{E}-05$ & 330 & 147.0 & 12.2 \\
\hline U-234 & 7.5E-03 & 55 & 300,625 & 25,052 \\
\hline U-235 & 1.1E-04 & 55 & 4,409 & 367 \\
\hline U-236 & $1.4 \mathrm{E}-03$ & 55 & 56,117 & 4,676 \\
\hline U-238 & 2.3E-03 & 55 & 92,192 & 7,683 \\
\hline Pu-238 & $9.1 E-02$ & 55 & $3,647,587$ & 303,966 \\
\hline Pu-239 & $9.1 \mathrm{E}-02$ & 55 & $3,647,587$ & 303,966 \\
\hline Pu-240 & $9.1 \mathrm{E}-02$ & 55 & $3,647,587$ & 303,966 \\
\hline Pu-241 & $1.1 E+00$ & 85 & $28,529,930$ & $2,377,494$ \\
\hline $\mathrm{Pu}-242$ & $9.1 E-02$ & 55 & $3,647,587$ & 303,966 \\
\hline Np-237 & $2.2 E-05$ & 55 & 881.8 & 73.5 \\
\hline Am-241 & 9.1E-02 & 55 & $3,647,587$ & 303,966 \\
\hline
\end{tabular}

WSRC-TR-94-0427

Rev: $1(10 / 17 / 94)$

Page 36 of 48

* the weights required to exceed the MRQ are 1/1000th of these WAC volumes. 


\section{Cumulative Activity}

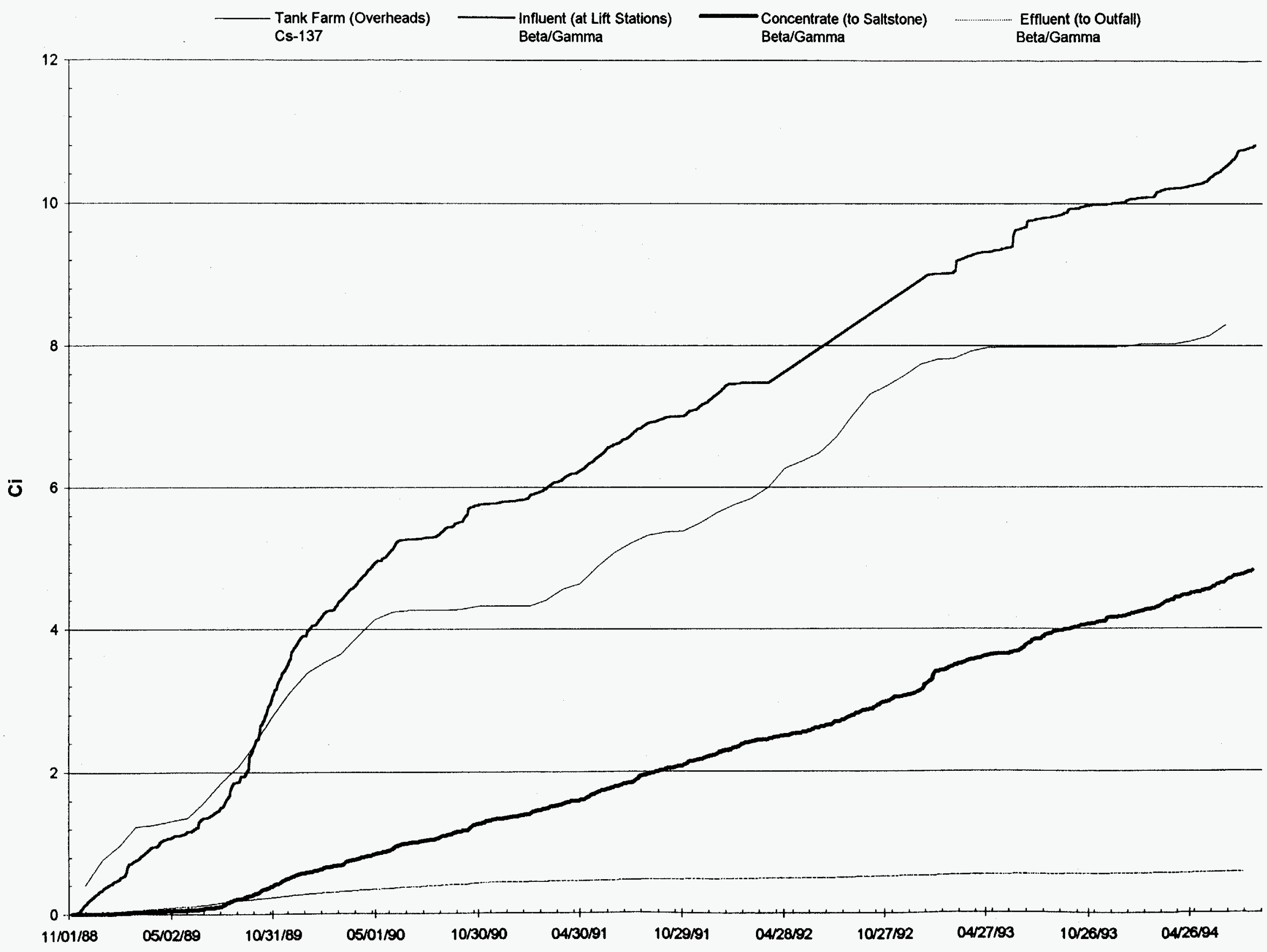




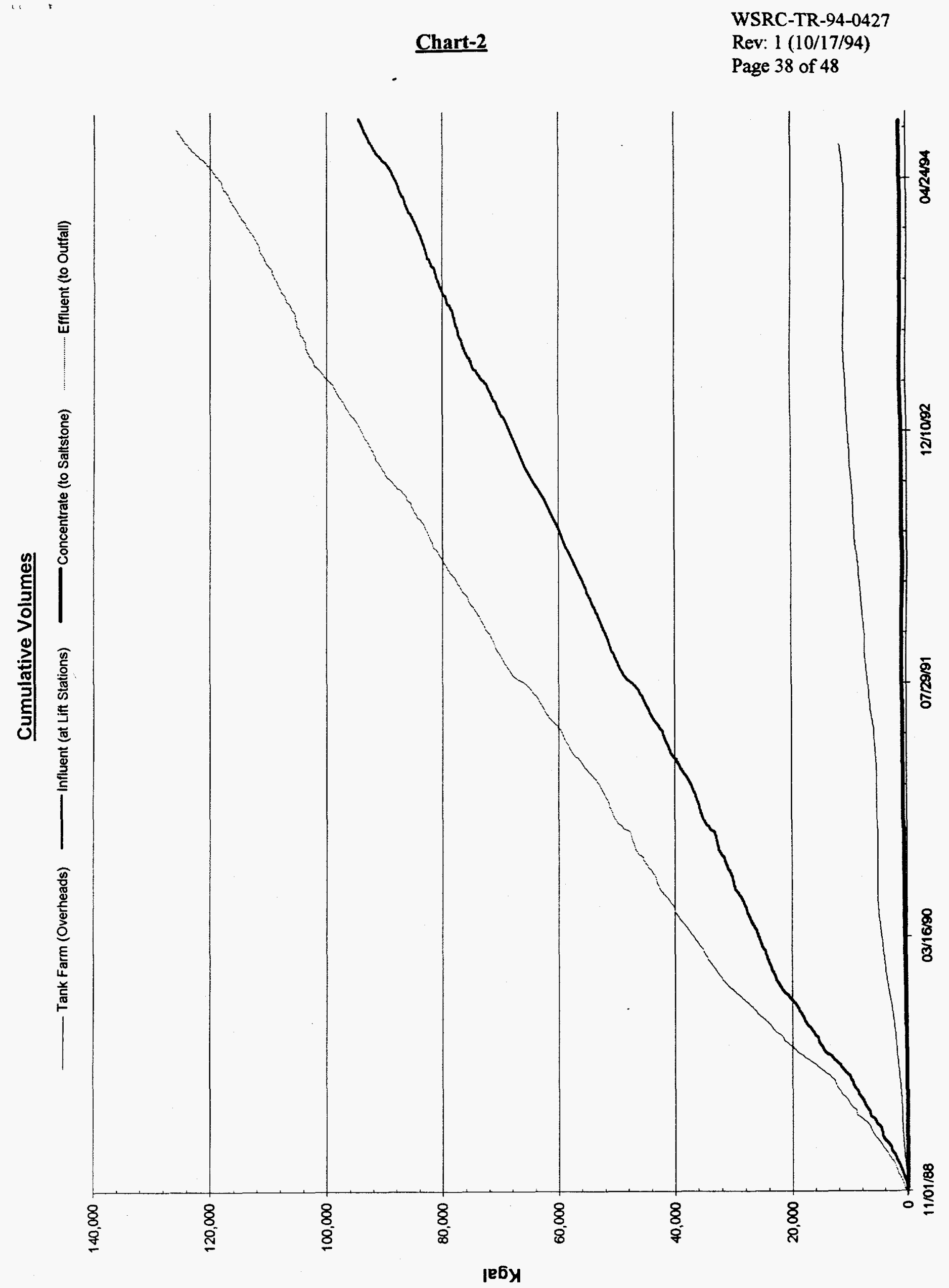


Chart-3

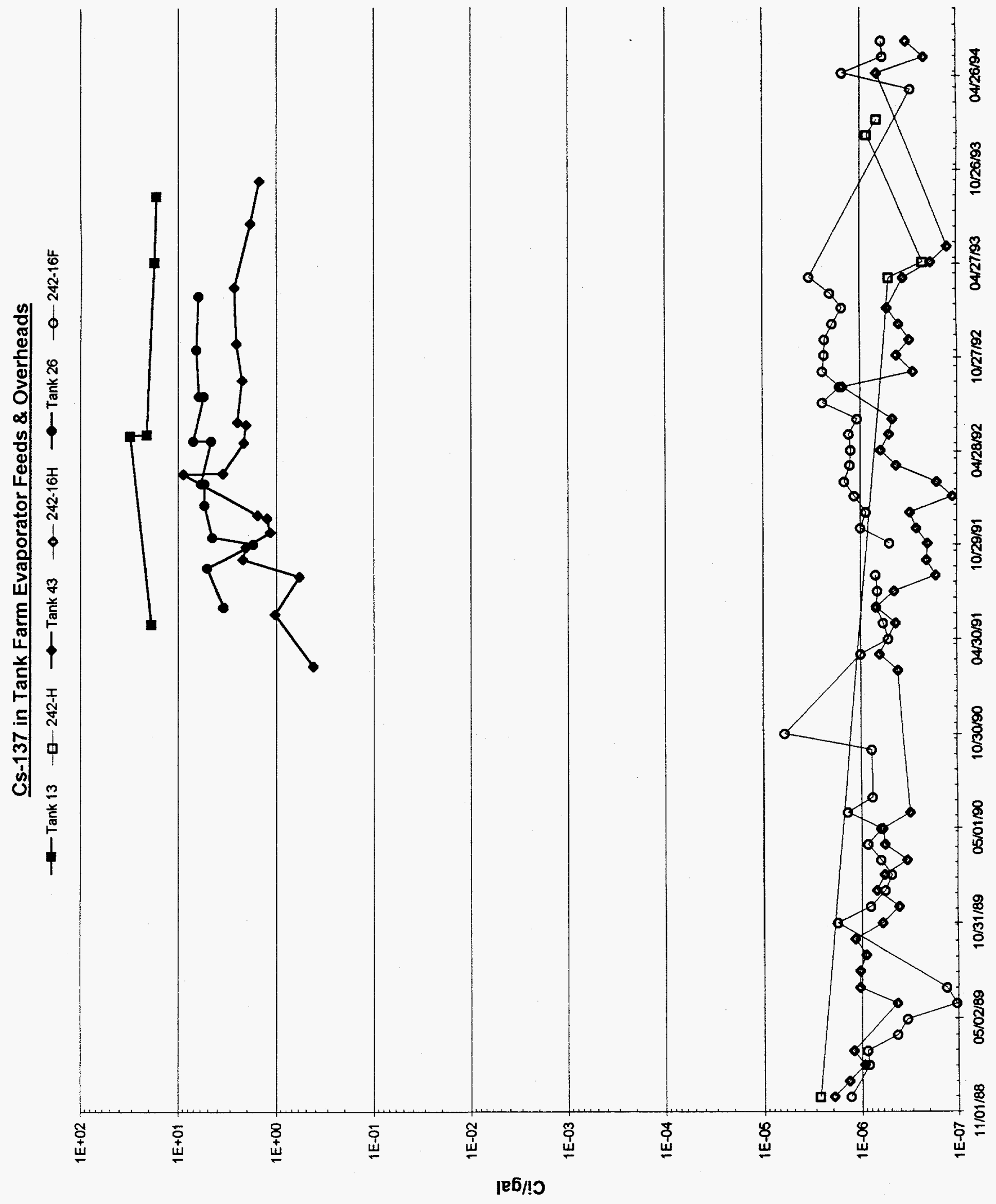

WSRC-TR-94-0427

Rev: 1 (10/17/94)

Page 39 of 48 
Chart-4

Rev: $1(10 / 17 / 94)$

Page 40 of 48

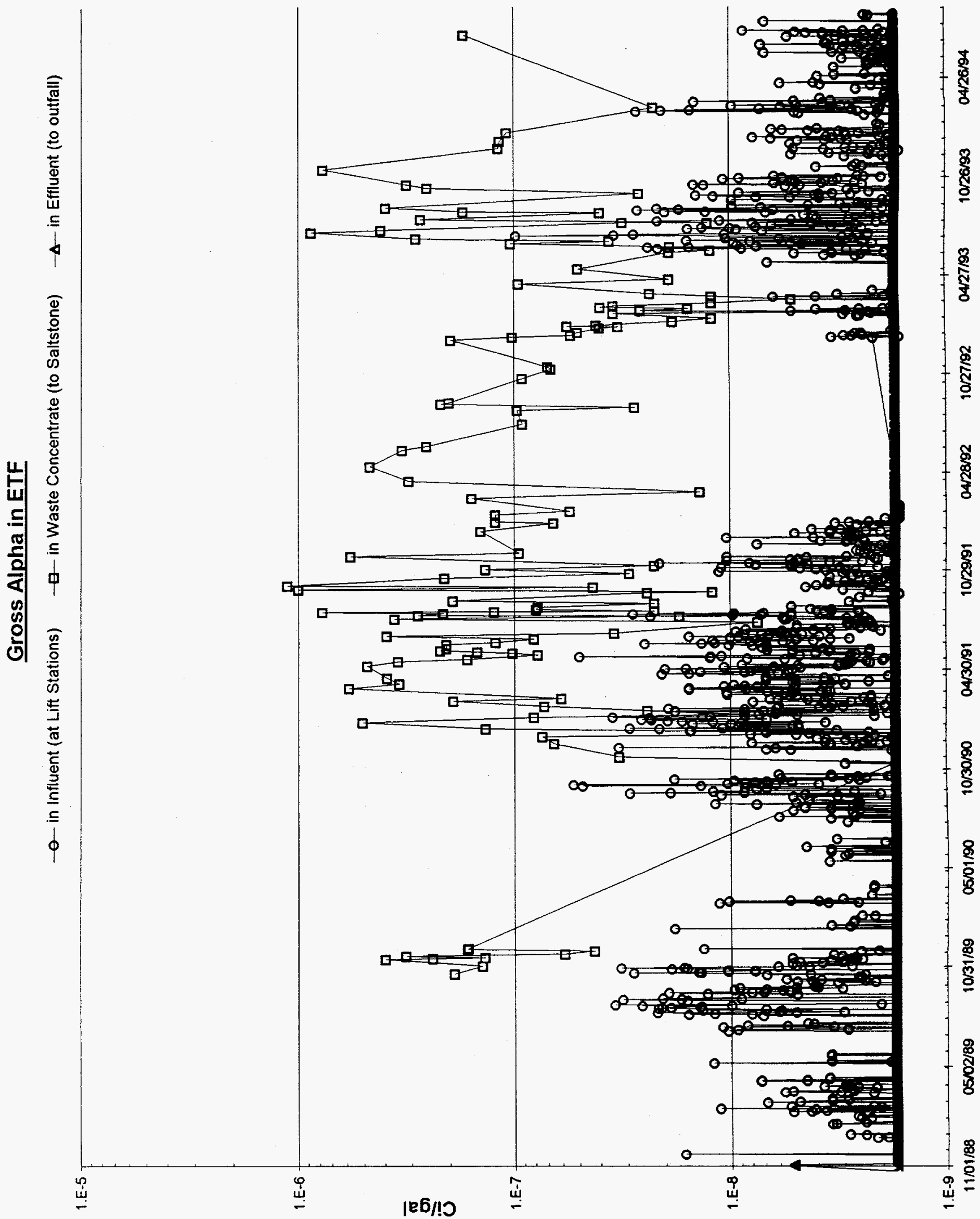


WSRC-TR-94-0427

Chart-5

Rev: 1 (10/17/94)

Page 41 of 48
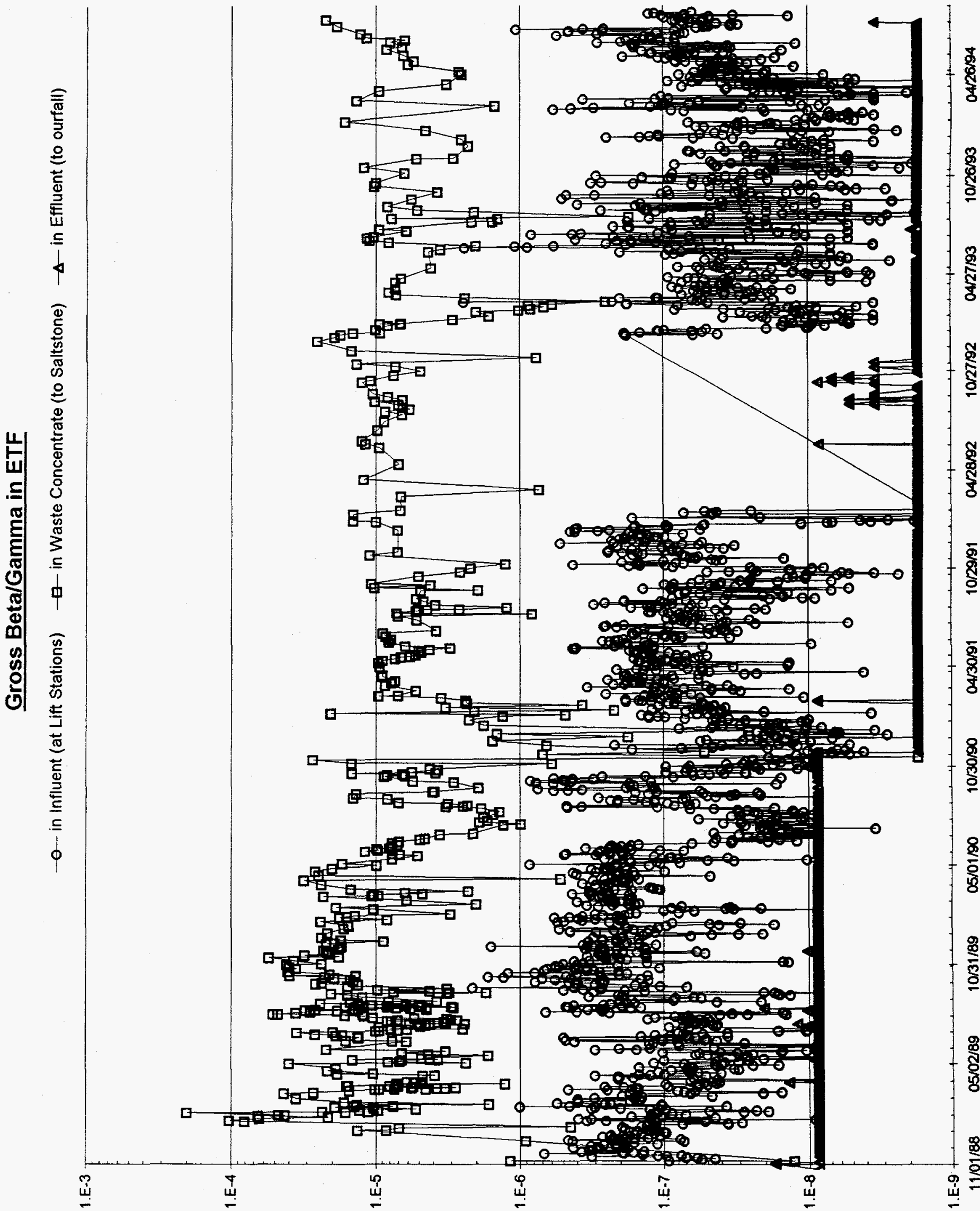

|e6/!? 
Chart-6

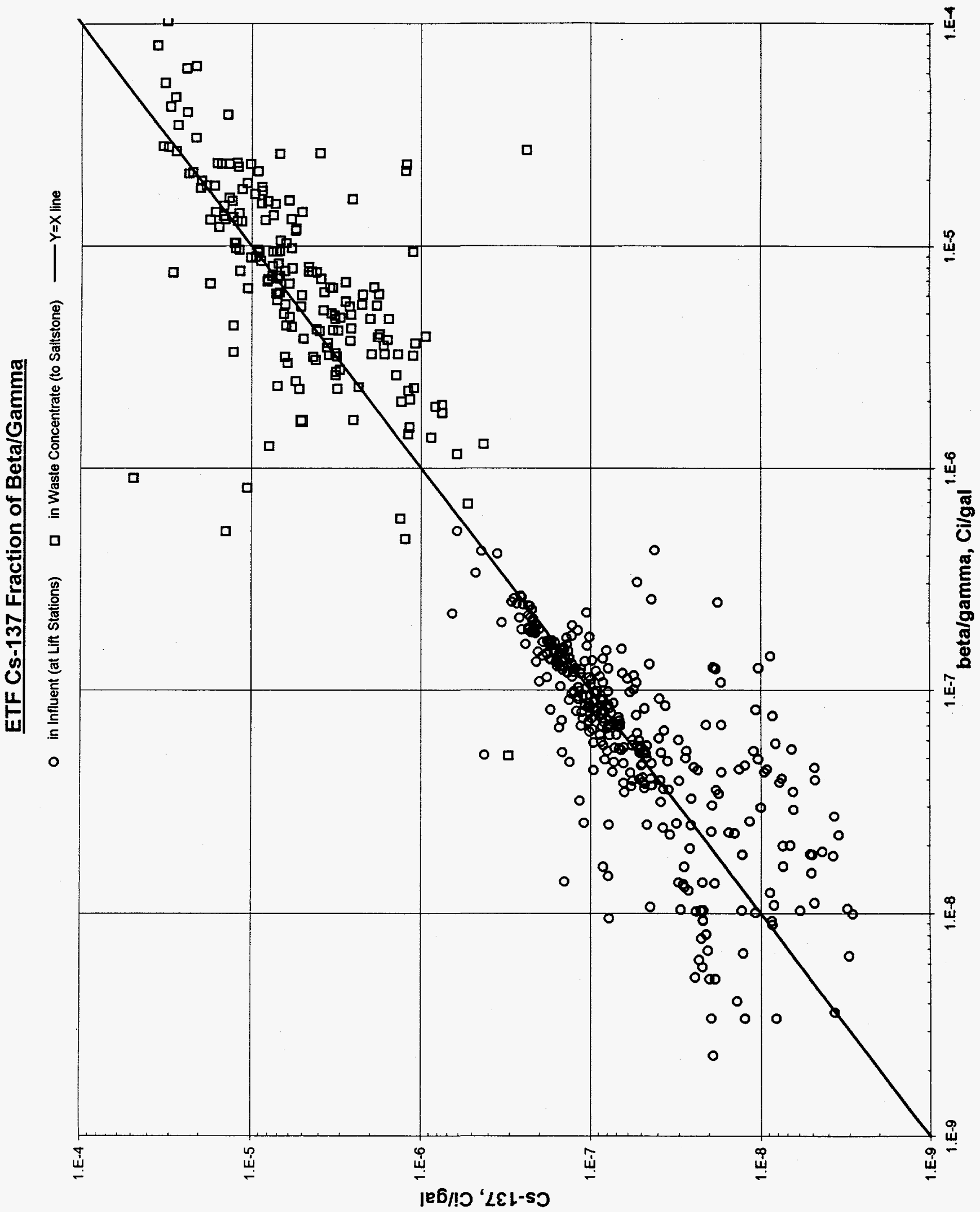


Chart-7

WSRC-TR-94-0427

Rev: 1 (10/17/94)

Page 43 of 48

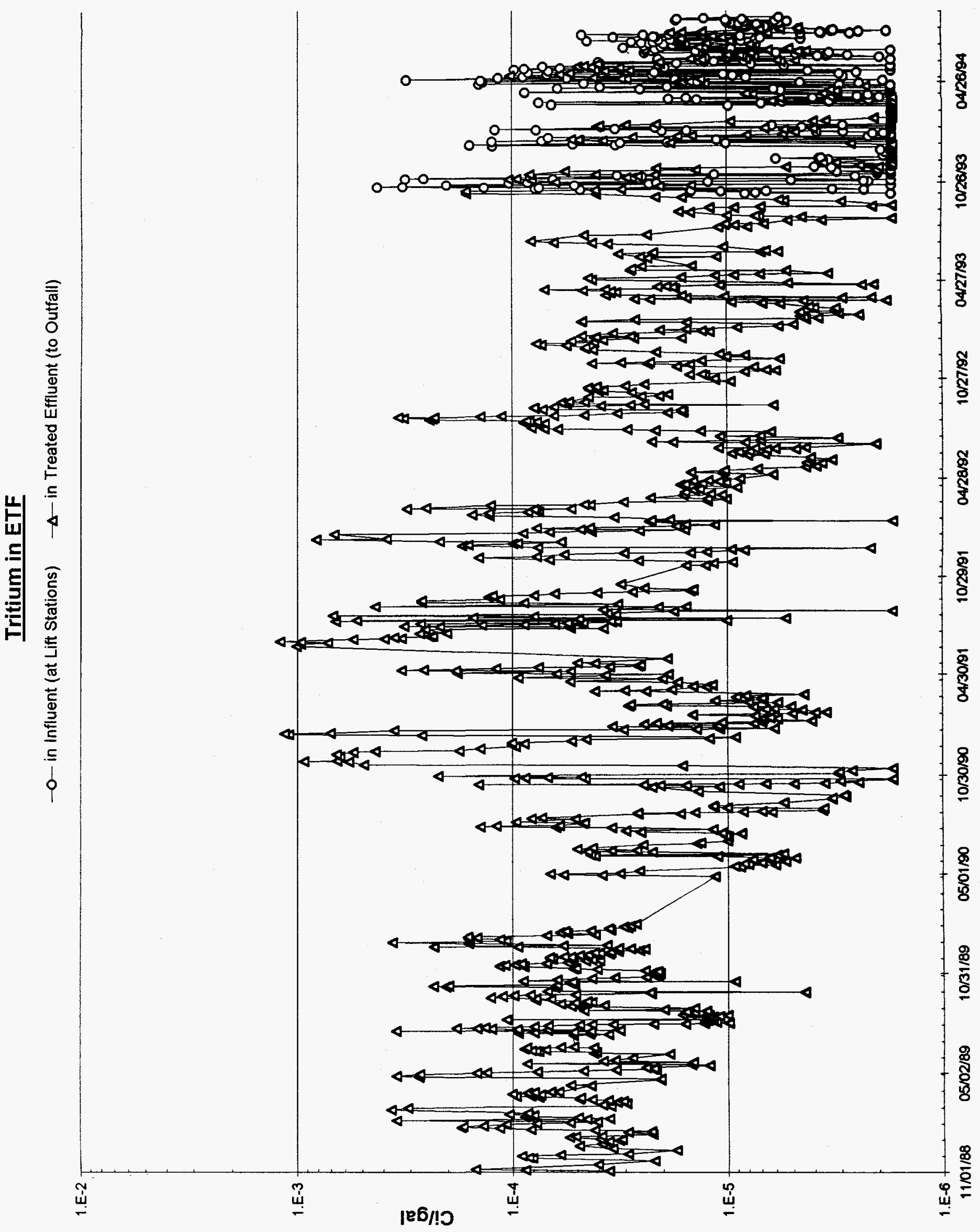




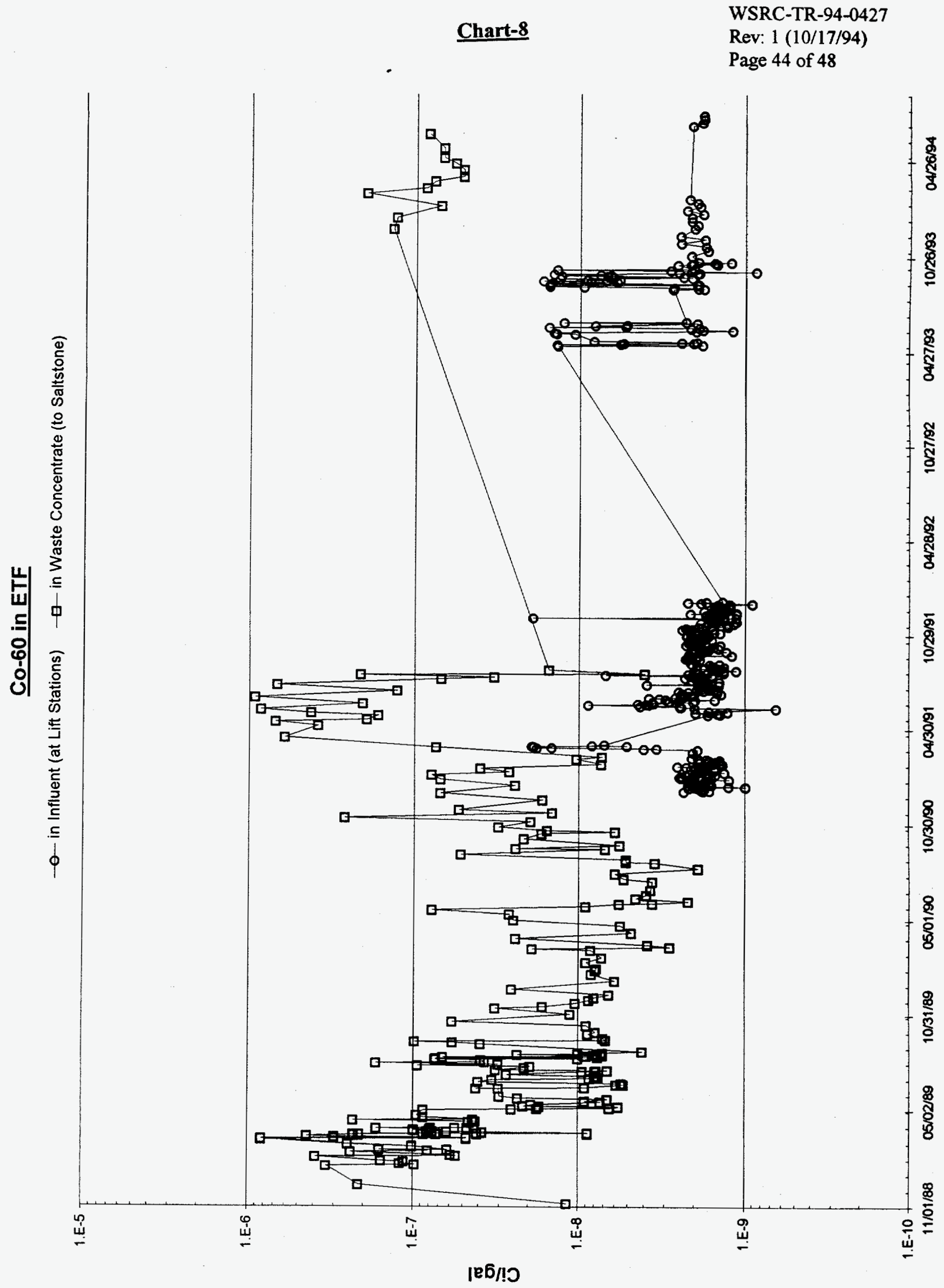


Chart-9

WSRC-TR-94-0427

Rev: 1 (10/17/94)

Page 45 of 48

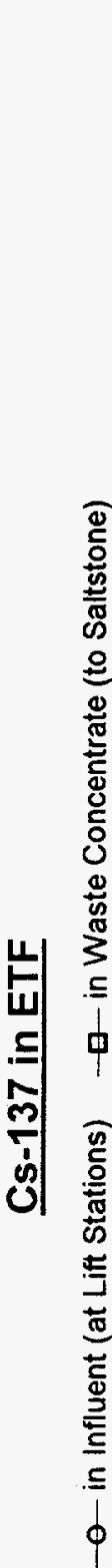

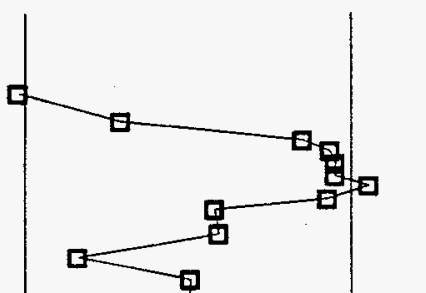

$10-10$
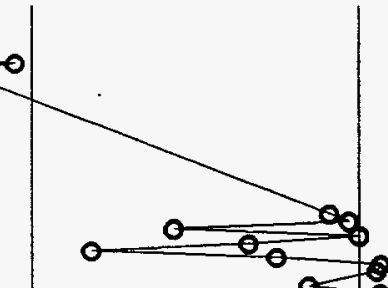

㗹

8 
Chart-10

WSRC-TR-94-0427

Rev: 1 (10/17/94)

Page 46 of 48

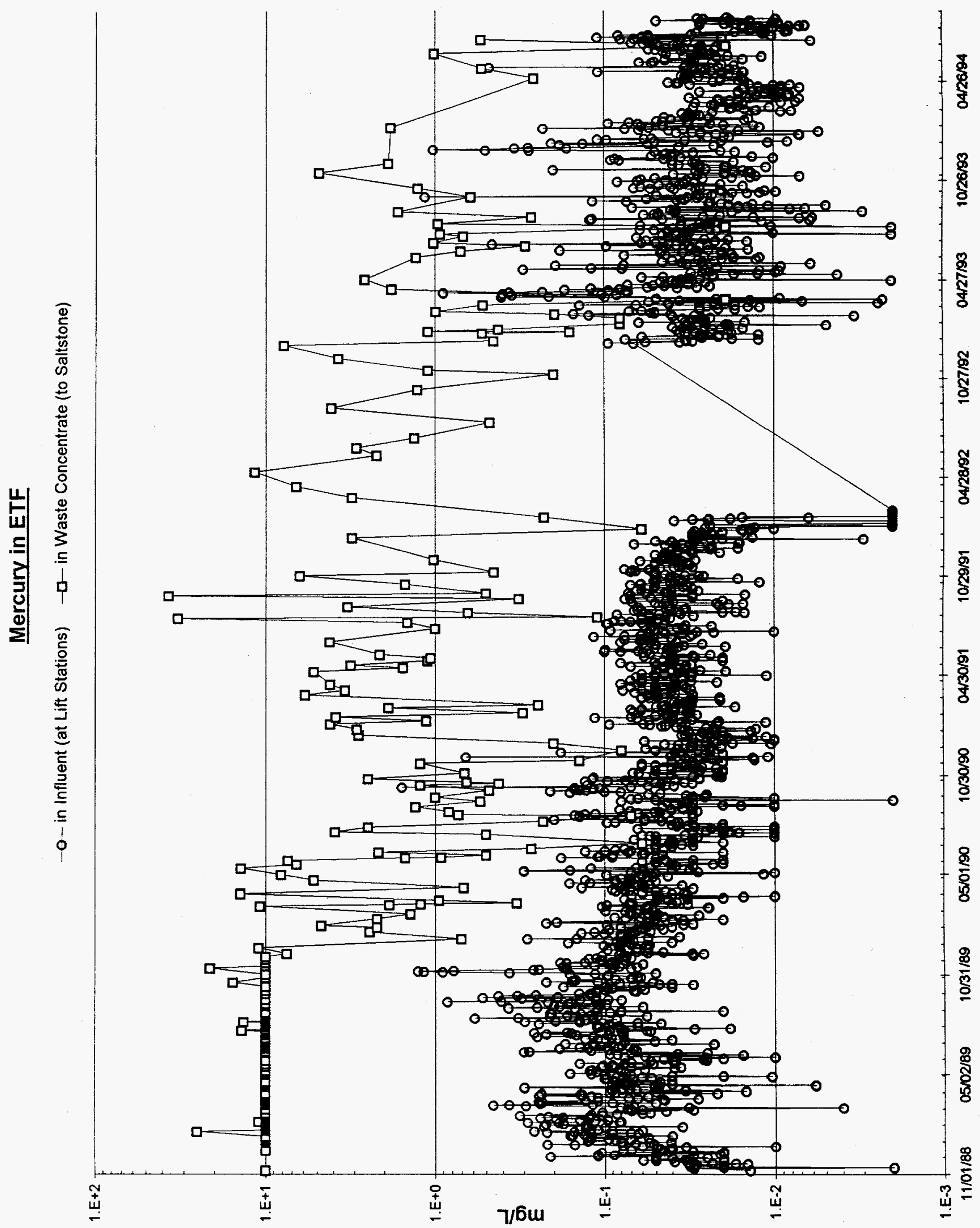




\section{Chart-11}

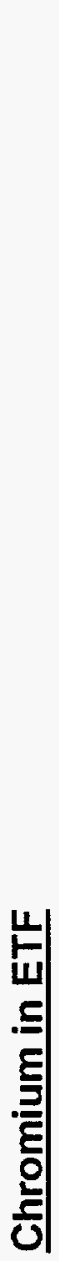


WSRC-TR-94-0427

Rev: 1 (10/17/94)

Page 47 of 48

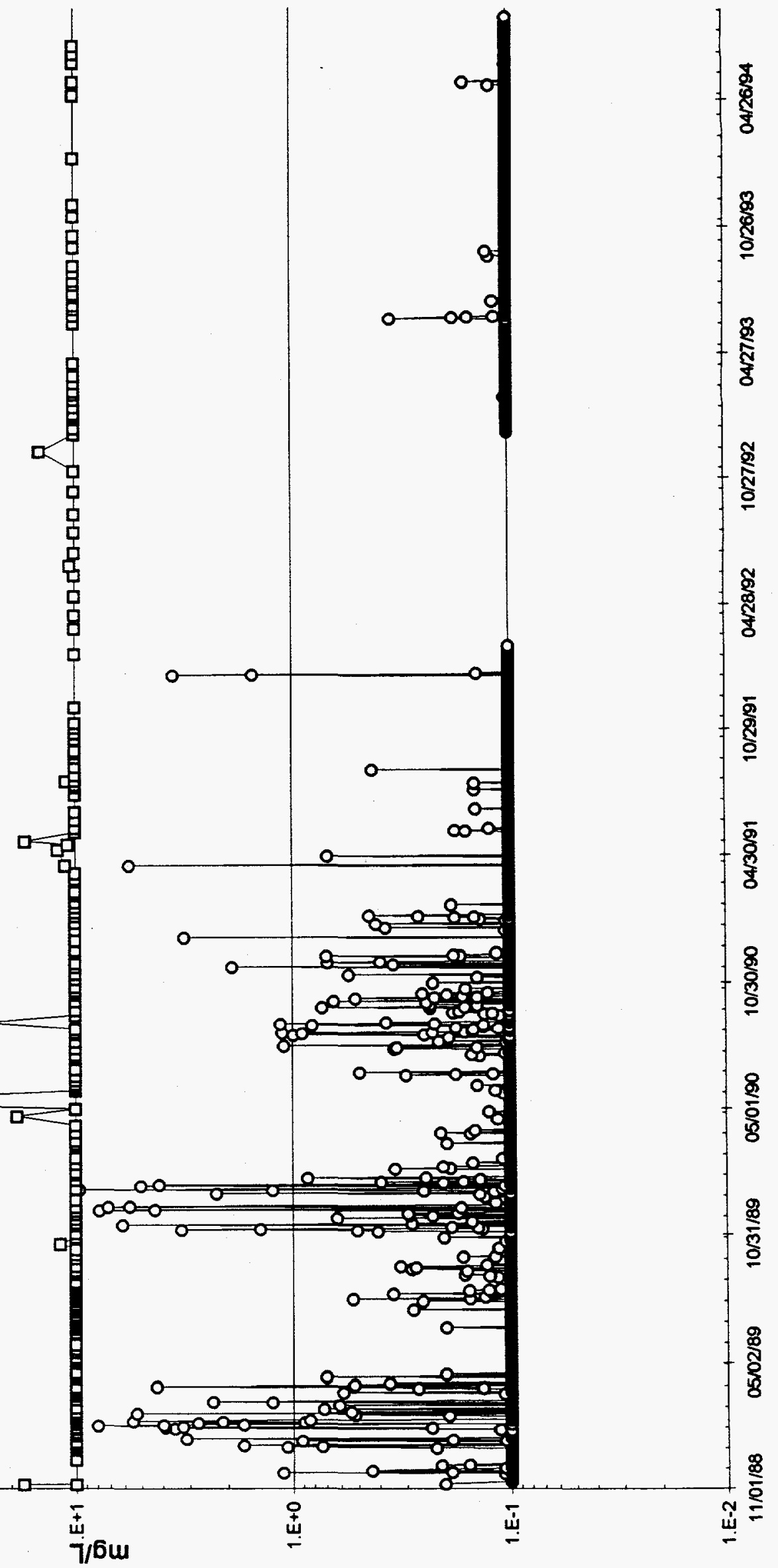




\section{Chart-12}

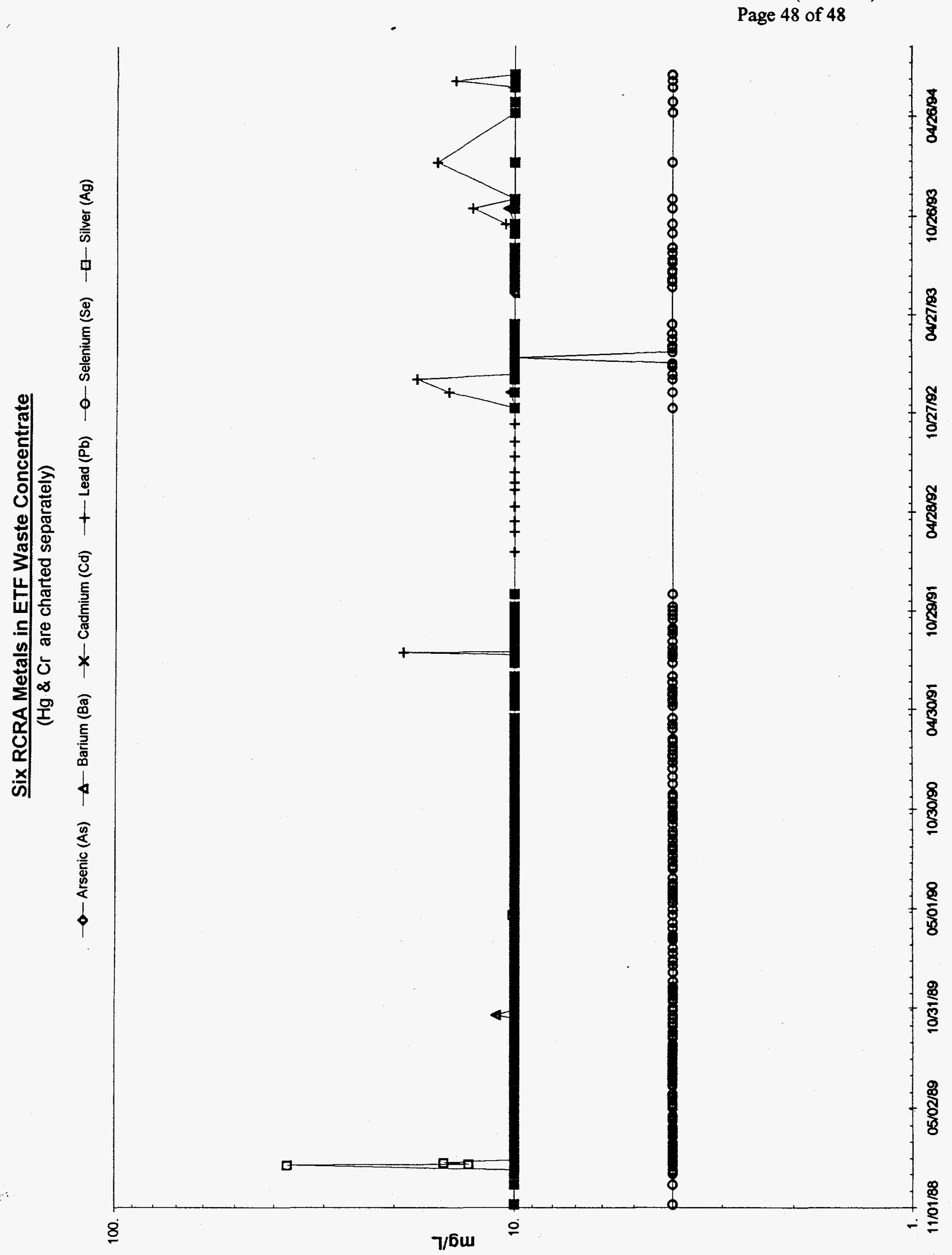

WSRC-TR-94-0427

Rev: 1 (10/17/94)

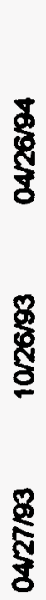

ญิ

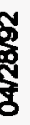

옹

还

\&్ర

$\frac{8}{9}$

$\frac{8}{8}$

$\frac{8}{8}$

\section{爰}

